RAFAEL DE OLIVEIRA ANDRETTE

\title{
"EFEITO DE CAMPOS ELÉTRICOS EXÓGENOS EM CÉLULAS TUMORAIS - UTILIZAÇÃO EM QUIMIOTERAPIA DE CÉLULAS MELANOCÍTICAS B16F10"
}

Tese apresentada ao Programa de PósGraduação Interunidades em Biotecnologia - USP/Instituto Butantan/ IPT, para a obtenção do Título de Doutor em Biotecnologia.

São Paulo 2012 
RAFAEL DE OLIVEIRA ANDRETTE

\section{"EFEITO DE CAMPOS ELÉTRICOS EXÓGENOS EM CÉLULAS TUMORAIS - UTILIZAÇÃO EM QUIMIOTERAPIA DE CÉLULAS MELANOCÍTICAS B16F10"}

Tese apresentada ao Programa de PósGraduação Interunidades em Biotecnologia - USP/Instituto Butantan/ IPT, para a obtenção do Título de Doutor em Biotecnologia.

Área de Concentração: Biotecnologia

Orientador: Prof. Dr. João Dias de Toledo Arruda Neto

Co-Orientador: Prof. Dr. Durvanei Augusto Maria

Versão Original

São Paulo

2012 
DADOS DE CATALOGAÇÃO NA PUBLICAÇÃO (CIP)

Serviço de Biblioteca e Informação Biomédica do

Instituto de Ciências Biomédicas da Universidade de São Paulo

(c) reprodução total

\section{Andrette, Rafael de Oliveira.}

Efeito de campos elétricos exógenos em células tumorais utilização em quimioterapia de células melanocíticas B16F10 / Rafael de Oliveira Andrette. -- São Paulo, 2012.

Orientador: João Dias de Toledo Arruda Neto.

Tese (Doutorado) - Universidade de São Paulo. Instituto de Ciências Biomédicas. Programa de Pós-Graduação Interunidades em Biotecnologia USP/IPT/Instituto Butantan. Área de concentração: Biotecnologia. Linha de pesquisa: Física Biológica

Versão do título para o inglês: Exogenous electric fields effects in tumoral cells - use in chemotherapy of melanocytic cells B16F10.

\section{Descritores: 1. Física Molecular 2. Biofísica 3. Oncologia} 4. Quimioterapia 5.Biologia molecular I. Neto, João Dias de Toledo Arruda II. Universidade de São Paulo. Instituto de Ciências Biomédicas. Programa de Pós-Graduação Interunidades em Biotecnologia USP/IPT/Instituto Butantan III. Título. 


\section{UNIVERSIDADE DE SÃO PAULO}

\section{Programa de Pós-Graduação Interunidades em Biotecnologia}

Universidade de São Paulo, Instituto Butantan, Instituto de Pesquisas Tecnológicas

Candidato(a): $\quad$ Rafael de Oliveira Andrette.

Título da Tese: $\quad$ Efeito de campos elétricos exógenos em células tumorais utilização em quimioterapia de células melanocíticas B16F10.

Orientador(a): $\quad$ João Dias de Toledo Arruda Neto.

A Comissão Julgadora dos trabalhos de Defesa da Tese de Doutorado, em sessão pública realizada a considerou
( ) Aprovado(a)
( ) Reprovado(a)

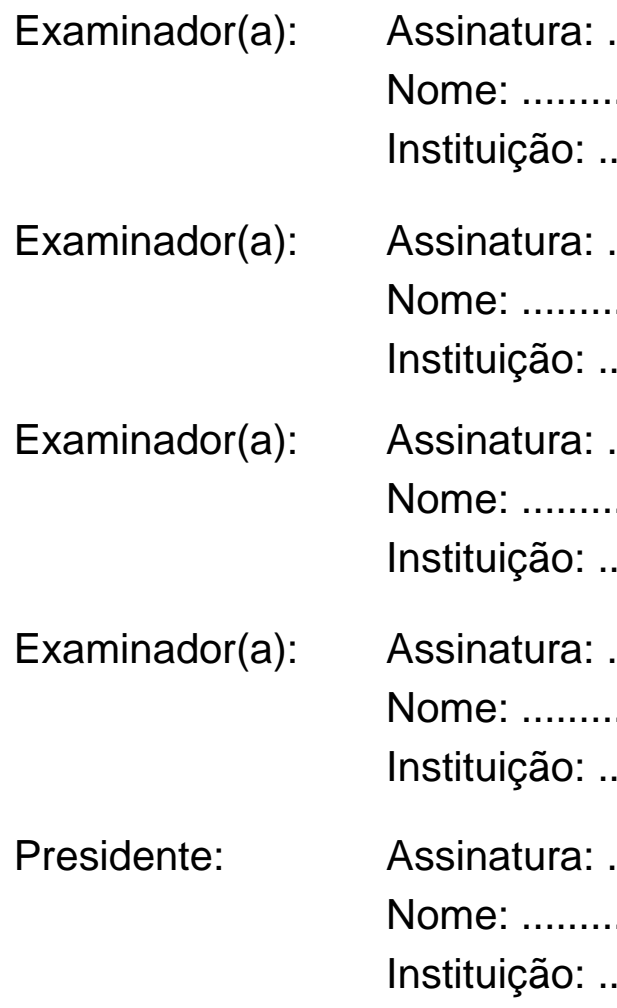


A todos que se dedicam e se envolvem com os mistérios da existência e do Saber 


\section{AGRADECIMENTOS}

Ao professor João Dias de Toledo Arruda Neto, que com o seu comportamento, saber e atitude se tornaram a pedra angular das minhas metas e aspirações. Sua presença foi fundamental para persistir e acreditar na longa jornada de crescimento pessoal por para realização da Tese e muito além.

Ao CNEN - Comissão Nacional de Energia Nuclear, que financiou a pesquisa e com isso permitiu a realização do curso.

Ao Professor Dr. Durvanei Augusto Maria, por me aceitar em seu Laboratório, fornecer os recursos para a execução dessa obra e apresentar idéias, meios e auxilio na pesquisa. Sua disposição em executar pessoalmente etapas criticas no trabalho se tornaram fundamentais na execução da Tese.

Aos membros do Laboratório de Bioquímica do Instituto Butantan, que promoveram experiências únicas de amadurecimento. Com destaque especial para:

Fernanda Faião Flores, presença fundamental e muito bem vinda em todas as etapas e fases do trabalho, com sua disposição, alegria, consultoria e atitude. Atuando com inestimável auxílio em todos os momentos. O valor especial dessa amizade se tornou o maior presente dos últimos anos com a alegria proporcionada.

As demais amizades, que não serão esquecidas:

Miryam Palomino, pelos inúmeros favores e disposição;

Dona Vilma, por ser uma "mãe" diligente e preocupada em auxiliar em cada momento;

Sonia Will, por auxiliar diretamente na execução prática do trabalho com os cultivos finais e muitos outros serviços a qual sempre estarei em débito.

Aos colegas e amigas do Instituto de Física:

Érika Cavalcante, com imenso carinho e gratidão por essa amizade especial;

Lena de Castro, agradecido pela sua perspectiva frenética e profunda; 
Juliana Peçanha, sempre presente para auxiliar e sabiamente puxar a orelha;

Eliana Lima, pela prestatividade me diversos pontos ao longo desses anos;

e Aymara Aragon, por sua atitude sempre amistosa e prestativa.

Aos amigos e colegas do Laboratório que muito auxiliaram e deixaram saudades:

Aline "Chapolete”, Álvaro Galdos, Amanda Olivoto, Ana Rita de Toledo Pizza, Camila Machado, Dayane Alcantara, Rodrigo Silveira e Norma Andrades Ikeda.

As pessoas que se voluntariaram para auxiliar na execução da obra, de forma direta ou indireta, em especial:

Thiago Calsolari, onde a confiança e o auxílio continuamente me relembram que jamais estarei realmente só nos desafios.

Com carinho e atenção para os demais colaboradores, que disponibilizaram a auxiliar:

Alessandra Bianquini, e sua postura sempre preocupada e atenta;

Fabiana Vilaça, sempre instigando o saber para além do horizonte conhecido;

e os amigos de décadas Ricardo Pedro e Cristiane Tabarelli. Com pequenas atitudes que revelam o valor de uma amizade que não esmorece.

E principalmente a minha mãe, por ser companheira de sonhos e reflexões, além do apoio eterno. E minha irmã por estar presente e compreensiva me cada momento da jornada. E ao meu pai in memória, sempre presente em sonhos.

E há muitas outras pessoas que fizeram a diferença no conjunto da obra. 
"Pelo fato de conceber idéias, o homem se torna um homem novo, que, vivendo na finitude, se orienta para o pólo do infinito" Edmund Husserl 


\section{RESUMO}

ANDRETTE, R. A. Efeito de Campos Elétricos Exógenos em Células Tumorais utilização em quimioterapia de células melanocíticas B16F10. 2012. $113 \mathrm{f}$. Tese (Doutorado em Biotecnologia) - Programa de Pós-graduação Interunidades em Biotecnologia, Universidade de São Paulo, São Paulo, 2012.

A célula submetida a danos pela ação de agentes físicos e químicos sofre alterações no seu metabolismo desencadeando diversos sinais para efetuar o reparo. Quando o dano for do tipo DSB (Double Strand Break - dano na dupla fita) em DNA, um dos sinais atestados experimentalmente é um pulso elétrico extremamente rápido (um transiente elétrico) e intrinsecamente presente em todas as células. Com isso seria possível, em princípio, interferir no processo de reparação do DNA pela exposição a campos elétricos exógenos. Neste trabalho exploramos a possibilidade de uso terapêutico desses campos de forma complementar ao tratamento de neoplasias, expondo-as simultaneamente a campos elétricos e quimioterápicos. O quimioterápico utilizado para induzir DSB foi o Etoposídeo com exposição combinada a Campos Elétricos Estáticos (CEE) de $1000 \mathrm{~V} / \mathrm{cm}$. Estudamos a linhagem tumoral de melanoma murino B16F10 e fibroblastos humanos normais (FN1). Foram mensuradas as condições de viabilidade pelo teste de citotoxicidade - MTT(comparadas com o Paclitaxel PCF) em função da concentração, bem como análise em função do tempo de exposição, concomitante de Anexina V e Iodeto de Propídio (PI), apoptose via Caspase 3 e potencial mitocondrial via Rodamina 123 para períodos de 2, 4, 6 e 24 horas. Também foi realizada uma análise qualitativa da concentração celular e morfologia, via coloração com Vermelho Neutro, através de microscopia óptica. Todos os testes quantitativos foram avaliados quanto à significância estatística via o teste ANOVA. Os resultados referentes aos efeitos isolados do CEE indicaram uma redução média de quase $25 \%$ na viabilidade via MTT, e diminuição média do potencial mitocondrial de $15 \%$ em ambas as linhagens estudadas. Nenhum aumento de morte celular foi detectado pela ação isolada do campo elétrico. Os resultados combinados do CEE com o Etoposídeo induziram um aumento expressivo na mortalidade celular, reduzindo a $\mathrm{IC}_{50}$ do Etoposídeo de $0,49 \mathrm{mmol}$ para $0,20 \mathrm{mmol}$ na linhagem tumoral $\mathrm{B} 16 \mathrm{~F} 10$, e de $0,46 \mathrm{mmol}$ para 0,15 mmol nas células de fibroblasto FN1. A combinação do CEE com o paclitaxel não resultou em qualquer redução da viabilidade celular. Com concentrações de 0,212 e 0,425 mmol de Etoposídeo, e exposição simultânea ao campo elétrico, mensurou-se uma redução média de $54 \%$ na viabilidade. Quantificou-se um aumento médio de $15 \%$ na apoptose, via Caspase 3, após $2 \mathrm{~h}$ em células FN1 e 4h em células B16F10, dobrando-se os valores obtidos isoladamente ao Etoposídeo nesses mesmos períodos de tempo. A detecção da apoptose e necrose via Anexina V/PI revelou um aumento de 20 para $40 \%$ na mortalidade com o tratamento combinado. Os resultados indicam que há uma redução no metabolismo mitocondrial pela ação isolada do CEE nas células, sem resultar em mortalidade. O tratamento combinado do campo elétrico com o quimioterápico Etoposídeo indica a ocorrência de uma interferência seletiva no mecanismo de reparo para danos do tipo DSB, neutralizando a sinalização de reparo. Como resultado, há um acumulo de danos no DNA que desencadeiam os processos de morte celular mensurados.

Palavras chave: Campos Elétricos Estáticos. Quimiossensibilização. Melanoma. Interferência Elétrica em Reparo. Indutor de Apoptose. Quebra na Dupla Fita. 


\begin{abstract}
ANDRETTE, R. A. Exogenous Electric Fields Effects in Tumoral Cells - Use in chemotherapy of melanocytic cells B16F10. 2012. 113 p. Thesis (PhD in Biotechnology) - Programa de Pós-Graduação Interunidades em Biotecnologia, Universidade de São Paulo, São Paulo, 2012.
\end{abstract}

A cell submitted to damages caused by physical and chemical agents undergoes alterations in its metabolism, giving rise to many signals in order to accomplish repair. When damage in DNA is a DSB (Double Strand Break), one of the signals experimentally observed, and described by several biological cell models, is a very fast electrical pulse (an electric transient) present in all cells. Giving this, it would be possible, in principle, to interferer in the DNA repairing process by exposure to exogenous electric fields. The possibility of therapeutic usage of electric fields as complementary intervention in cancer treatment, by means of simultaneous exposure of tumors to chemotherapy and electric fields is investigated and addressed in this work. It was used the chemotherapic Etoposide to induce DSB with combined exposition to 1,000 V/cm Static Electric Fields (SEF). We studied the tumor strain of the murine melanoma B16F10 and of normal human fibroblasts (FN1). Viability conditions were measured with the cytotoxicity test - MTT - (compared with the antineoplastic Paclitaxel PCF) as function of concentration, as well as analysis as function of exposure time, concomitant Annexine V and Propidium Iodine (PI), apoptosis via Caspase 3 and mitochondrial potential via Rodamin 123 at time periods of 2, 4, 6 and 24 hours. Was also performed a qualitative analysis of cellular concentration and morphology by coloring with Neutral Red, through optical microscopy. All quantitative tests were checked for statistical significance by the ANOVA test. Results referring to isolated effects of the SEF showed an average viability reduction of $25 \%$, via MTT, and an average decrease of $15 \%$, approximately, in the mitochondrial potential for both of the studied strains. Exposure only to the electric field didn't cause any cell death. The combined results of SEF with Etoposide induced a substantial increase of cell deaths, reducing Etoposide $\mathrm{IC}_{50}$ from $0.49 \mathrm{mmol}$ to $0.20 \mathrm{mmol}$ in the tumor strain $\mathrm{B} 16 \mathrm{~F} 10$, and from 0.46 mmol to $0.15 \mathrm{mmol}$ in the fibroblast cells FN1. Association of the SEF with paclitaxel didn't alter the cell viability. With Etoposide concentrations of 0.212 and $0.425 \mathrm{mmol}$, and simultaneous exposure to the electric field, an average viability reduction of $54 \%$ was measured. An apoptosis average increase of $15 \%$, via Caspase 3, was evaluated after $2 \mathrm{~h}$ in FN1 cells and after $4 \mathrm{~h}$ in B16F10 cells. The sole application of Etoposide, in these same times, doubled the apoptosis. Detection of apoptosis and necrosis via Annexine V/PI exhibited cell death increase from $20 \%$ to $40 \%$ when combined with electric field exposure. The results point to a reduction of the mitochondrial metabolism by the sole exposure of cells to the electric field, without leading to cell death. The combined treatment of electric field with the chemotherapyc Etoposide indicates the existence of a selective interference in the repairing mechanism for DSB damages, neutralizing in this way the repair signaling. As a result, the accumulation of damages in DNA triggers cell death processes.

Key words: Static Electric Field. Chemosensibilization. Melanoma. Electric Interference in Repair. Apoptosis Inducer. Double Strand Break. 


\section{LISTA DE ILUSTRAÇÕES}

Figura 1.1 - Alterações morfológicas da morte celular por apoptose e necrose. $\quad 22$

Figura 1.2 - Mapa das reações protéicas que desencadeiam a apoptose. 23

Figura 1.3 - Ligação química do Etoposídeo a Topoisomerase II. 26

Figura 1.4 - Representação esquemática de um Campo Elétrico. 28

Figura 1.5 - Ação do Campo Elétrico nas proteínas de reparo. 35

Figura 4.1 - Fotografia das placas de petri com células B16F10. 49

Figura 4.2 - Fotografia das placas de petri com células FN1. 50

Figura 4.3 - Imagem do grupo controle de células B16F10 e células expostas ao quimioterápico Etoposídeo.

Figura 4.4 - Imagem do grupo controle de células B16F10 e células expostas ao Campo Elétrico Estático.

Figura 4.5 - Imagem das células B16F10 expostas ao Campo Elétrico Estático e ao quimioterápico Etoposídeo.

Figura 4.6 - Imagem do grupo controle de células FN1 e células expostas ao Campo Elétrico Estático.

Figura 4.7 - Imagem das células FN1 expostas ao Campo Elétrico Estático e ao quimioterápico Etoposídeo.

Figura 4.8 - Gráfico da ação isolada do Campo Elétrico Estático na viabilidade celular.

Figura 4.9 - Marcação com Caspase 3 das células B16F10 do grupo controle e do grupo exposto ao Campo Elétrico Estático.

Figura 4.10 - Marcação com Caspase 3 das células FN1 do grupo controle e do grupo exposto ao Campo Elétrico Estático.

Figura 4.11 - Gráficos de apoptose via Caspase 3 do grupo controle e do grupo exposto ao Campo Elétrico Estático.

Figura 4.12 - Imagens dos histogramas das células marcadas com rodamina 123.

Figura 4.13 - Gráficos das mitocôndrias ativas.

Figura 4.14 - Gráficos da atividade mitocondrial no grupo controle e exposto ao Campo Elétrico Estático.

Figura 4.15 - Imagens representativas de células B16F10 marcadas com anexina V/PI do grupo controle e do grupo exposto ao Campo Elétrico Estático.

Figura 4.16 - Imagens representativas de células FN1 marcadas com anexina V/PI do grupo controle e do grupo exposto ao Campo Elétrico Estático.

Figura 4.17 - Gráficos das células B16F10 marcadas com anexina V/PI do grupo controle e do grupo exposto ao Campo Elétrico Estático.

Figura 4.18 - Gráficos das células FN1 marcadas com anexina V/PI do grupo controle e do grupo exposto ao Campo Elétrico Estático. 
Figura 4.20 - Gráficos com as curvas de citotoxicidade do Etoposídeo e Campo Elétrico Estático pelo MTT.

Figura 4.21 - Reta de tendência dos valores de citotoxicidade do Etoposídeo.

Figura 4.22 - Ajuste dos resultados do efeito associado do Campo Elétrico Estático com o Etoposídeo em uma curva de tendência.

Figura 4.23 - Curvas de viabilidade celular das culturas B16F10 (A) e FN1(B) em função do quimioterápico Paclitaxel.

Figura 4.24 - Gráfico com as curvas da razão do Campo Elétrico Estático em função do Etoposídeo.

Figura 4.25 - Valores de viabilidade com intervalos de tempo entre o Etoposídeo e o Campo Elétrico Estático.

Figura 4.26 - Imagens representativas de células B16F10 marcadas com caspase 3 dos grupos tratados com Etoposídeo.

Figura 4.27 - Imagens representativas de células FN1 marcadas com caspase 3 dos grupos tratados com Etoposídeo.

Figura 4.28 - Gráficos de apoptose via Caspase 3 dos grupos tratados com Etoposídeo.

Figura 4.29 - Imagens representativas de células B16F10 marcadas com anexina V/PI.

Figura 4.30 - Imagens representativas de células FN1 marcadas com anexina V/PI.

Figura 4.31 - Gráficos de células B16F10 marcadas com anexina V/PI nos grupos tratados com Etoposídeo.

Figura 4.32 - Gráficos de células de FN1 marcadas com anexina V/PI nos grupos tratados com Etoposídeo.

Figura 4.33 - Histogramas das células marcadas com rodamina 123 para todos os grupos experimentais.

Figura 4.34 - Gráficos do potencial mitocondrial para todos os grupos experimentais.

Figura 5.1 - Transporte de íons na membrana mitocondrial.

Figura 5.2 - Orientação para a passagem de íons na membrana interna da mitocôndria.

Figura 5.3 - Efeito do Campo Elétrico Estático no transporte de íons.

Figura 5.4 - Curvas com comportamento do decaimento exponencial e Lei de Potência.

Figura 5.5 - Processo de sinalização na ativação da ATM. 


\section{SUMÁRIO}

1 INTRODUÇÃO 16

1.1 A Célula Tumoral e suas Características Biológicas 17

1.1.1 Ciclo Celular e a Genética Tumoral 17

2 O Melanoma 18

1.2. A Morte Celular 19

$\begin{array}{lll}\text { 1.2.1 Necrose } & 20\end{array}$

$\begin{array}{lll}\text { 1.2.2 Apoptose } & 21\end{array}$

1.3 Topoisomerases e Antineoplásicos 22

1.3.1. $\quad$ Apoptose e a Topoisomerase II 23

1.3.2. Mecanismos de Ação e classificação das Drogas Antineoplásicas

1.3.3. Drogas Utilizadas no Tratamento do Câncer 25

1.4 Campos Elétricos 26

1.4.1 Caracterização do Campo Elétrico 27

1.4.2 A Bioeletricidade e a Natureza Elétrica das Células 28

1.5 Efeitos de Campos Elétricos e Magnéticos em Células Tumorais 29

1.5.1 Uso de Corrente Alternada com Campos Elétricos de Alta Freqüência 30

1.5.2 Campo Elétrico Pulsado de Alta Intensidade 31

1.5.3 Campos Magnéticos combinados com Radiação Eletromagnética 31

1.5.4 Campos Elétricos Estáticos de Origem Fisiológica 31

1.6 A Sinalização Elétrica do DNA na Reparação Celular 34

2 OBJETIVOS 36

$2.1 \quad$ Objetivo Geral 37

2.2 Objetivos Específicos 37

3 MATERIAL E MÉTODOS 38

3.1 Organograma dos Experimentos Realizados 39

3.2 Linhagens Celulares e Reagentes 40

3.1.1 Melanoma Murino B16F10 40

3.1.2 Fibroblasto humano FN1 40

3.1.3 Reagentes e Soluções $\quad 40$

3.1.3.1 Meio de cultura RPMI- $1640 \quad 40$

3.1.3.2 Solução de Congelamento 40 
3.1.3.3 Solução de MTT 40

3.1.3.4 Tripsina 41

3.1.3.5 Solução tampão Fac's Flow 41

3.1.3.6 Vermelho Neutro 41

3.1.3.7 Quimioterápicos 41

3.3 Metodologia 41

3.3.1 Cultivo das Células $\quad 41$

3.3.2 Cultura para os Experimentos $\quad 42$

3.3.3 Exposições ao Campo Elétrico Estático 42

3.3.4 Avaliação da Citotoxicidade - via MTT- do CEE nas Células 42

3.3.5 Análises via Citometria de Fluxo 44

3.3.5.1 Caspase $3 \quad 45$

3.3.5.2 Rodamina 123 46

3.3.5.3 Anexina-V e PI 46

3.3.6 Análise Colorimétrica 46

3.4 Análise Estatística dos Resultados 47

4 RESULTADOS 48

4.1 Análises qualitativas via coloração com Vermelho Neutro 49

4.1.1 Amostras Coradas de Células de Melanoma B16F10 49

4.2 Análise Quantitativa dos efeitos do Campo Elétrico Estático 57

4.2.1 Viabilidade Celular via MTT

4.2.2 Apoptose Quantificada Via Caspase 3 58

4.2.3 Potencial de Membrana Mitocondrial 60

4.2.4 Morte Celular Quantificada Via Anexina V/PI 61

4.3 Análise quantitativa do CEE combinado com Quimioterápico 64

4.2.5 Viabilidade Celular com Etoposídeo e CEE via MTT 64

4.2.6 Apoptose com Etoposídeo e CEE Quantificada Via Caspase 3

4.2.7 Morte Celular por Etoposídeo e CEE Quantificada via Anexina V/PI 71

4.2.8 Potencial de Membrana Mitocondrial com Etoposídeo e CEE $\quad 74$

5 DISCUSSÃO 76

5.1 Efeitos Isolados do Campo Elétrico Estático (CEE) 77

$\begin{array}{lll}\text { 5.1.1 Efeitos do CEE na viabilidade celular } & 77\end{array}$ 
5.1.2 Efeitos do CEE na Atividade Mitocondrial 77

5.2 Efeitos do CEE combinados com o Etoposídeo 80

5.2.4 Análise Qualitativa dos dados $\quad 80$

5.2.5 Ação dos Quimioterápicos Combinados ao CEE 81

5.2.6 O Crescimento da Mortalidade Associado ao CEE 81

5.2.7 Efeitos do CEE nas Moléculas de Reparo 84

5.3 Destaques, Continuidade e Perspectivas Futuras 87

5.3.1 Destaques - Uso do CEE no Tratamento Tumoral 87

$\begin{array}{lll}\text { 5.3.2 Perspectivas futuras } & 88\end{array}$

6 CONCLUSÕES $\quad 89$

Referências $\quad 91$

$\begin{array}{ll}\text { APÊNDICE } & 107\end{array}$ 
1 INTRODUÇÃO 


\subsection{A Célula Tumoral e suas Características Biológicas}

Sob as leis naturais que regem o domínio da biologia, organismos celulares evoluíram para adaptações complexas objetivando a sobrevivência. De organismos unicelulares para a complexidade dos tecidos, as leis da seleção natural têm sido executadas de forma intrigante ao explorar todas as possibilidades e diversidades de comportamento.

Células tumorais que ultrapassam os limites homeostáticos e realizam uma divisão descontrolada de forma sustentável, adquirem diversas aberrações que impulsionam o crescimento, a sobrevivência, a migração e a invasão para se estabelecerem em órgãos distantes. Para conseguir essas proezas, as células tumorais necessitam superar as restrições homeostáticas condicionantes do meio multicelular, criando mecanismos metabólicos extremamente complexos (NATIONAL CANCER INSTITUTE, 2011). A condição evolutiva que permite a gênese tumoral muitas vezes também impede o sucesso do tratamento ao produzir cânceres resistentes, e muitas vezes intratáveis. Aumentando a imensa dificuldade do desafio há o fato de que mais de 100 tipos de células, de diferentes tecidos, são suscetíveis ao desenvolvimento tumoral (INCA; 2011).

A fim de combater eficazmente o tumor devemos compreender os princípios básicos e processos biológicos que conferem o crescimento agressivo e imortal, independentemente da sua origem. Na escala celular é preciso entender os circuitos complexos que determinam o ciclo de divisão, sobrevivência, migração e invasão, assim como sua capacidade de tolerar falhas no seqüenciamento genético e resistência incomum aos danos resultantes das divisões desordenadas (NATIONAL CANCER INSTITUTE, 2011).

\subsubsection{Ciclo Celular e a Genética Tumoral}

O desenvolvimento do câncer tem ligação direta com eventos no ciclo celular, que consiste em uma série de eventos programados que resultam em uma procissão precisamente regulada com fases distintas: G0, G1, S, G2 e M (ALBERTS et al, 2008). O relógio do ciclo celular serve como um regulador mestre deste evento, sinalizando o momento para as células se dividirem, fase de repouso e inibição do crescimento quando não é necessário. O ciclo não é um evento isolado nas células do tecido, e tem por objetivo garantir que a seqüência correta de eventos ocorra no momento certo e nas circunstâncias adequadas (na presença de sinais de crescimento, nutrição, integridade do DNA, etc). Uma perturbação em uma das proteínas envolvidas no ciclo celular pode levar ao crescimento 
anormal e/ou à propagação das células aberrantes que, por sua vez, promovem a gênese tumoral (MCGILL e MCGLADE, 2005).

Quando a integridade do ciclo celular está preservada as células conservam a capacidade de se dividir quando necessário, e mais importante, manter a capacidade de permanecer em repouso quando o crescimento não é indicado. A interrupção do ciclo celular por agentes externos pode levar à proliferação descontrolada, um dos primeiros passos envolvidos no desenvolvimento tumoral (HARTWELL e KASTAN, 1994; CHAO et al, 2011).

Geneticamente o câncer surge do acúmulo de mutações genéticas e alterações epigenéticas que alteram a função dos genes e sua expressão. Nos últimos anos muitos e novos oncogenes e genes supressores de tumor têm surgido a partir de análises genômicas de cânceres humanos (STRATTON et al, 2009). Coletivamente, mutações somáticas nos pares de bases foram identificadas em muitos genes por meio de esforços de seqüenciamento do DNA (FORBES et al, 2008). Análises com a tecnologia de microarrays, ou microarranjos de DNA, têm sido utilizadas para medir os ganhos e perdas em número de cópias do genoma, bem como a expressão alterada dos genes. Estes esforços têm fornecido informações importantes sobre os mecanismos biológicos subjacentes ao desenvolvimento da tumorigênese, permitindo caracterizar as condições genômicas que levam ao desenvolvimento de neoplasias e novas abordagens para a intervenção clínica (STUART e SELLERS 2009; BERGER et al, 2010).

Com a formação da massa tumoral primária, cinco características tumorais aparecem com a progressão da doença: a auto-suficiência em sinais de crescimento; a insensibilidade à inibição do crescimento (ou aos fatores de anticrescimento) e sinais de morte celular programada; o potencial de replicação ilimitada e geração de vasos sanguíneos (angiogênese) (HANAHAN e WEINBERG; INCA, 2011).

\subsection{2 $\underline{\text { O Melanoma }}$}

O melanoma é uma doença neoplásica produzida pela transformação maligna dos melanócitos normais, células responsáveis pela produção do pigmento melanina. Essas células migram no desenvolvimento fetal para diversas áreas, incluindo a pele, meninges, membranas mucosas, esôfago superior, e os olhos. Em cada um desses locais os melanócitos demonstraram um potencial de transformação maligna, mas o local mais 
comumente associado com a transformação melanocítica é a pele, na região entre a junção da derme e epiderme (GIROUARD, 2011).

O Brasil contribui com apenas $4 \%$ das neoplasias malignas dos tumores de pele que ocorrem no mundo (sendo este o mais freqüente, correspondendo a $25 \%$ de todos os tumores malignos registrados no país) e tem predominância em adultos de pele clara Apesar de uma alta taxa de cura para o melanoma localizado na fase inicial (98,3\% de taxa de sobrevida em 5 anos), suas características de metástase rápida e proliferação para locais distantes do ponto de origem, favorecem uma rápida queda da taxa de sobrevivência para 16\% em 5 anos (INCA, 2011).

Atualmente, a espessura vertical do tumor em milímetros (denominada índice de Breslow) fornece a melhor indicação do estágio do melanoma (BALCH et al, 2001). Tal parâmetro pode ser aperfeiçoado utilizando-se outros referencias, tais como: presença de ulceração, a penetração das células tumorais nas camadas cutâneas, a taxa de mitose, a presença de proteínas expressas na metástase, à disseminação do tumor para os linfonodos, e a evidência de metástases à distância (PAWLIK E SONDAK, 2003; BARNHOLTZSLOAN et al; WAINSTEIN e BELFORT, 2004).

Assim como $70 \%$ das mutações somáticas que induzem a oncogênese, os melanomas sofrem supressões gênicas que afetam o cromossomo no lócus 9p21. Sua importância para o ciclo é explicada em parte pelo seu papel, que permite duas transcrições distintas nos genes supressores de tumor: p16INK4A e p19ARF (STARK e HAYWARD, 2007). A perda do gene p16INK4A impede a supressão na atividade do blastoma via aumento da ativação do complexo D1 CDK4/6 ciclina e a perda do complexo IRA, resultando na supressão da atividade da p53 através da ativação ampliada da MDM2. Desse modo, a exclusão do lócus inteiro realiza a inativação de dois caminhos críticos para o desenvolvimento da supressão tumoral (KANNAN, SHARPLESS, XU; 2003). Esta desregulamentação é conhecida por ser fundamental para a imortalização de células primárias e de sua eventual transformação oncogênica (BARDEESY, et al.; 2001).

\subsection{A Morte Celular}

O desenvolvimento e a manutenção dos organismos multicelulares dependem de uma interação entre as células que o constituem. No desenvolvimento embrionário, muitas células produzidas em excesso são levadas à morte, contribuindo para a formação dos 
órgãos e tecidos (MEIER, FINCH e EVAN, 2000). Durante muito tempo, a morte celular foi considerada um processo passivo de caráter degenerativo, que ocorre em situações de lesão celular, infecção e ausência de fatores de crescimento. Como conseqüência, a célula altera a integridade da membrana plasmática, aumenta o seu volume e perde as suas funções metabólicas (YU e CHOI, 2000). Entretanto, nem todos os eventos de morte celular são processos passivos. Organismos multicelulares são capazes de induzir a morte celular programada como resposta a estímulos intracelulares ou extracelulares (HENGARTNER, 2000). Os processos de morte celular podem ser classificados de acordo com suas características morfológicas e bioquímicas em: apoptose, autofagia, necrose, mitose catastrófica e senescência (OKADA e MAK, 2004; DIMRI, 2005). Em 2009, o Comitê da Nomenclatura em morte celular (DCNTs) propôs um conjunto de recomendações para a definição de células com morfologias distintas de mortes e para o uso adequado de terminologia relacionada à morte celular, incluindo "apoptose", "necrose" e "mitose catastrófica". Devido às descobertas bioquímicas dos últimos anos, o DCNTs atualizou as definições de morte celular de forma que pudessem ser enquadradas tanto as descobertas in vivo quanto in vitro (GALLUZZI et al, 2012). Dentro dos processos destacaremos os mecanismos de necrose e apoptose.

\subsection{1 $\quad \underline{\text { Necrose }}$}

A necrose é um tipo de morte na qual as células sofrem uma injúria que resulta no aumento do volume celular, agregação da cromatina, desorganização do citoplasma, perda da integridade da membrana plasmática e consequente ruptura celular (Figura 1.1). Durante a necrose, o conteúdo celular é liberado, causando dano às células vizinhas e uma reação inflamatória no local (DEGTEREV et al, 2005). Por muito tempo foi considerada uma resposta passiva aos danos celulares, um mecanismo meramente acidental de morte celular, definida pela ausência de características morfológicas de apoptose ou autofagia. (GALLUZZI et al, 2007; KROEMER et al, 2009). Estudos recentes indicam que a necrose também pode ser regulada geneticamente, (DEGTEREV et al, 2005; HITOMI, et al, 2008; CHO et al.; HE et al.; ZHANG et al.; 2009) indicando que a necrose pode ocorrer de forma regulamentada, com um papel de destaque em várias configurações fisiológicas e patológicas (VANDENABEELE et al, 2010).

Vários fatores podem induzir necrose regulamentada, incluindo danos no DNA (ZONG et al, 2004; BANO et al, 2005; CHO et al.; HE et al.; ZHANG et al.; 2009). Quando as caspases (e em particular a caspase-8) são inibidas por manipulações genéticas 
ou bloqueadas por agentes farmacológicos (por exemplo, produtos químicos inibidores da caspase), pode ocorrer a ativação da morte celular por necrose (GALLUZZI et al, 2007; CHO et al.; HE et al.; ZHANG et al, 2009; VANDENABEELE et al, 2010).

\subsection{2 $\quad$ Apoptose}

O termo "morte celular programada" foi proposto para designar um tipo de morte celular que ocorre de forma não acidental (LOCKSHIN e WILLIAMS, 1964; KERR, WYLLIE; CURRIE, 1972). A apoptose ocorre nas mais diversas situações, como por exemplo na organogênese e hematopoiese normal e patológica, na reposição fisiológica de certos tecidos maduros, na atrofia dos órgãos, na resposta inflamatória e na eliminação de células após dano celular por agentes genotóxicos (RANGANATH e NAGASHREE, 2005). A apoptose pode ser reconhecida por características morfológicas muito marcantes e coordenadas (Figura 1.1). De um modo geral, a apoptose é um fenômeno bastante rápido: ocorre uma retração da célula que causa perda da aderência com a matriz extracelular e células vizinhas. As organelas celulares mantêm a sua morfologia, com exceção, em alguns casos, das mitocôndrias, que podem apresentar ruptura da membrana externa. A cromatina sofre condensação e se concentra junto à membrana nuclear, que se mantém intacta; a membrana celular forma prolongamentos e o núcleo se desintegra em fragmentos envoltos pela membrana nuclear. Os prolongamentos da membrana celular aumentam em número e tamanho e rompem-se, originando estruturas contendo o conteúdo celular. Essas porções celulares envoltas pela membrana celular são denominadas corpos apoptóticos. Os corpos apoptóticos são rapidamente fagocitados por macrófagos e removidos sem causar um processo inflamatório (ZIEGLER e GROSCURTH, 2004) (Figura 1.1). Outra característica muito marcante da morte por apoptose é a fragmentação internucleossômica do DNA, que possui um padrão característico. A maioria dos tecidos sofre um constante processo de renovação celular graças ao equilíbrio entre proliferação e morte das células, caracterizada por um processo ativo de alterações morfológicas e bioquímicas, a apoptose. A apoptose é também um mecanismo de defesa, que é ativado sempre que ocorre uma invasão por agentes patogênicos, ou ainda quando o DNA for lesado. A compreensão dos mecanismos e das alterações nos componentes das vias apoptóticas e sua correlação com a ocorrência do câncer são importantes para o desenvolvimento de novas terapias e métodos de prevenção do câncer (GRIVICICH; REGNER e ROCHA, 2007). 
Figura 1.1 - Alterações morfológicas da morte celular por apoptose e necrose.

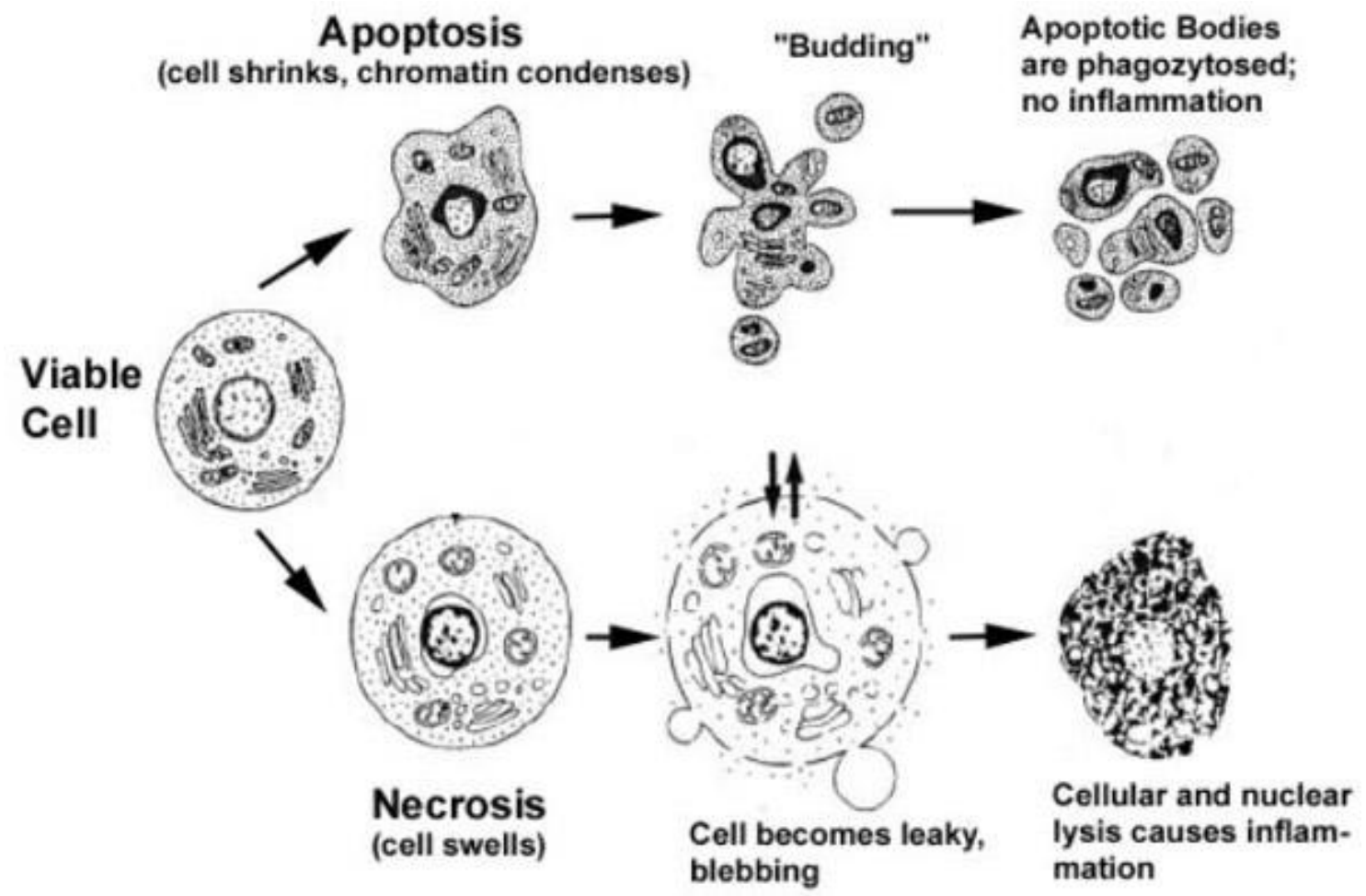

A apoptose apresenta redução no volume celular, condensação da cromatina e formação de corpos apoptóticos para fagocitose. Na necrose há expansão e rompimento da membrana com presença de lise celular, liberando seu conteúdo e provocando resposta inflamatória.

Fonte: CRUCHTEN e BROECK, 2002.

Os fenômenos de apoptose se dividem tradicionalmente em dos tipos: intrínseca e extrínseca. A apoptose intrínseca atua em resposta a várias condições de estresse intracelular (por exemplo, danos ao DNA e sinais de sobrecarga citosólica de $\mathrm{Ca}^{2+}$ ), em que os sinais pró-sobrevivência e pró-morte são gerados e convergem para um mecanismo de controle centrado na mitocôndria. Quando os sinais letais prevalecem, ocorre a permeabilização da membrana mitocondrial externa que leva à dissipação do potencial mitocondrial transmembrana, retenção da síntese de ATP mitocondrial e alteração no potencial mitocondrial em atividades dependentes de transporte. Além disso, as cadeias respiratórias ficam desacopladas gerando as espécies reativas de oxigênio e liberação de proteínas para o citosol que normalmente são confinadas dentro do espaço intermembranar mitocondrial (figura 1.2) (KROEMER, GALLUZZI e BRENNER, 2007).

A "apoptose extrínseca" é um termo amplamente utilizado para indicar casos de morte celular por apoptose induzidos por sinais de estresse extracelular; são captados e propagados pelos receptores transmembrana específicos (WAJANT, 2002; SHUTZE, 
TCHIKOV e SCHNEIDER-BRACHERT, 2008; MEHLEN e BREDESEN, 2011) A apoptose extrínseca pode ser iniciada pela ligação de ligantes letais como: o ligante FAS/CD95, o fator de necrose tumoral $\alpha$ (TNF $\alpha$ ) e superfamília de ligantes TNF (figura 1.2) (WAJANT, 2002).

Figura 1.2 - Mapa das reações protéicas que desencadeiam a apoptose.

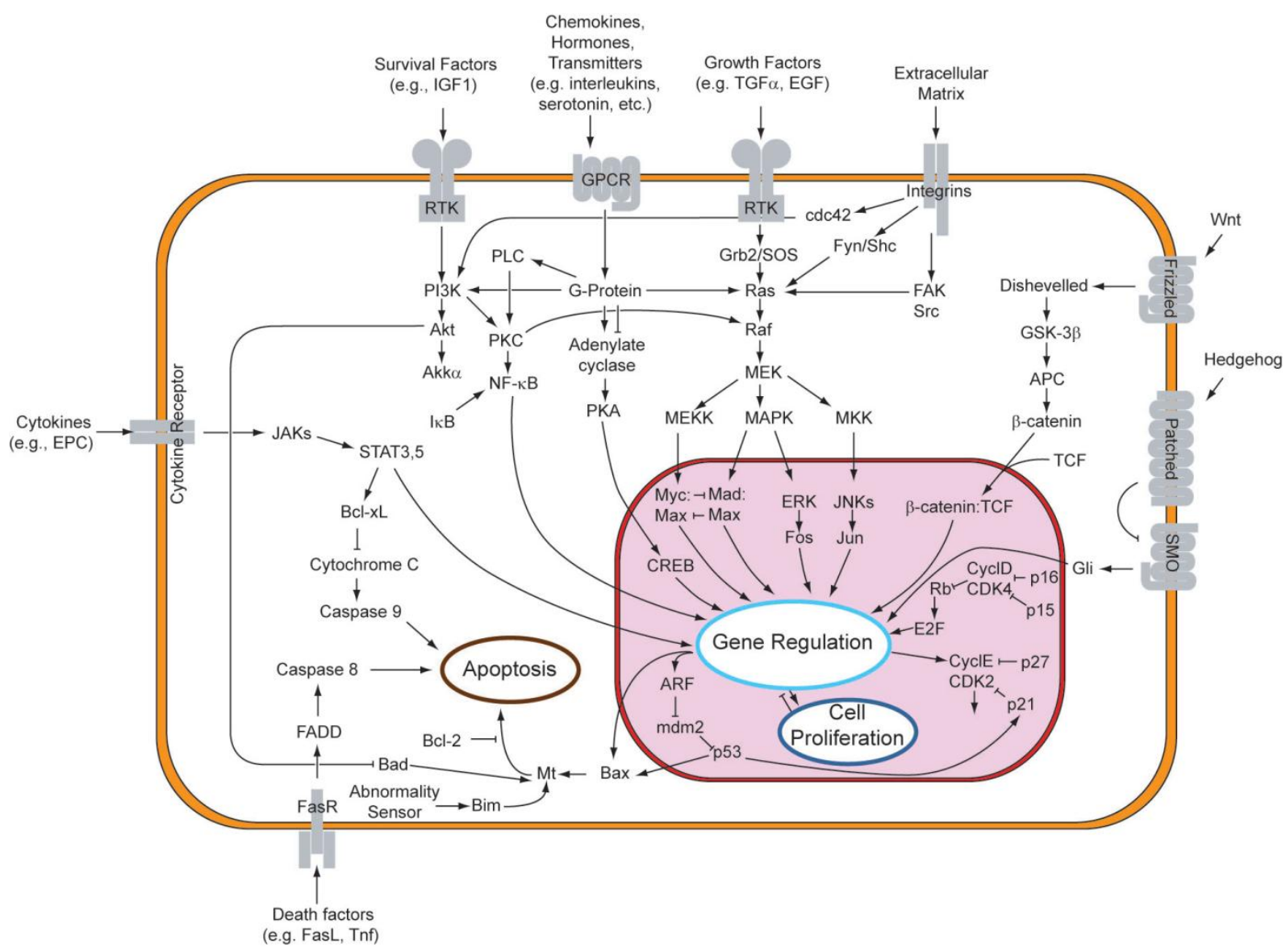

Os reguladores centrais de apoptose são uma classe de proteases denominadas caspases. As caspases iniciadoras (incluindo caspase $2,8,9,10,11$, e 12) são estreitamente ligadas aos sinais pró-apoptóticos. Uma vez ativadas, essas caspases clivam e ativam caspases efetoras que por sua vez executam a apoptose pela clivagem de proteínas. celulares específicas.

Fonte: Cell Signaling Technology (CST), 2011.

\subsection{Topoisomerases e Antineoplásicos}

As topoisomerases são enzimas do tipo ubiquitina que induzem uma quebra transitória no DNA (CHAMPOUX 2001; WANG 2002; POMMIER et al 2010). Entre elas destacamse as topoisomerases I e II (Top1 e Top2) que são particularmente relevantes para a apoptose, e devido a isso também são alvos de uma ampla gama de drogas antitumorais. A maioria dos medicamentos clínicos que visam Top1 ou Top2 converte as DNAtopoisomerase em indutores de quebras no DNA com danos irreversíveis, que iniciam o programa de apoptose (LIU, 1989; POMMIER 2006; NITISS 2009). A Topoisomerase II 
(Top2) é um importante alvo de drogas antitumorais, como o Etoposídeo, que são amplamente utilizadas em uma grande variedade de tumores. A maioria das drogas que alvejam Top2 induz danos ao DNA como uma consequiência direta da atividade catalítica da enzima. Todas as DNA topoisomerases são clivadas, formando um complexo covalente entre a enzima e o DNA, e agentes que perturbam o ciclo catalítico têm o potencial para interceptar a enzima e introduzir danos no DNA (figura 1.3) (DOMBERNOWSKY et al 1996; WALKER e NITISS 2002; BALDWIN e OSHEROFF 2005; CHOI et al.; VERBORG et al 2008; LIEU et al 2009). O dano ao DNA pela intervenção na topoisomerase inclui danos tanto em quebras na fita dupla (DSB) como nas proteínas covalentemente ligadas ao DNA. Agentes que provocam o aprisionamento de topoisomerases de DNA foram denominados "venenos de topoisomerase" ao matar as células, em grande parte, através de enzimas que mediam as vias de reparo aos danos, evento crítico na resposta clínica à redução de tumores. Além da importância clínica dada às drogas que tem a Top2 como alvo específico, essas drogas têm servido como compostos modelo para estudar as respostas celulares a danos no DNA. Diferentemente dos agentes alquilantes e das radiações ionizantes, o alvo dos venenos de topoisomerase são muito específicos, atuando em tipos específicos de danos ao DNA (NITISS et al, 2009).

A ação da Top2 é dividida entre dois monômeros, que clivam dois filamentos de DNA (cada monômero cortando um fio), levando a um estado intermediário de ligações covalente 5-fosfotirosil de ambas as subunidades do DNA. A geração da ligação fosfotirosil preserva a energia da ligação fosfodiéster, permitindo que a indução da quebra enzimática não necessite um co-fator de alta energia. Mesmo que Top2 não utilize o ciclo completo catalítico dependente de ATP, ainda necessita de reações de hidrólise por ATP para modular as mudanças conformacionais necessárias para o ciclo de reação completa. A enzima transitoriamente abre uma "porta" que permite a passagem da dupla fita de DNA intacta. Após esta passagem a ruptura é selada por reversão dos títulos fosfotirosil, reformando o DNA. Os venenos de Top2 interferem com as reações de quebra e reunificação da reparação (figura 1.3). Um dos principais mecanismos para interferir com a reação de quebra-reunificação é a inibição da enzima mediadora da religação; drogas como o Etoposídeo atuam com este tipo de inibição (ROBINSON e OSHEROFF 1991). Para outras drogas, como as elipticinas, não há evidência clara de inibição na religação, sendo possível que algumas outras drogas estimulem enzimas de clivagem que são mediadas pelo DNA (FROELICH-AMMON et al,1995; ROBINSON et al, 1992). 


\subsection{1 $\quad$ Apoptose e a Topoisomerase II}

Em alguns tipos de células, a apoptose depende do receptor de membrana FASs (também conhecido como APO-1 e CD95). FAS é um membro da família denominada fator de necrose tumoral (TNF). A ligação cruzada da FAS pelo seu ligante natural (FASL) induz a agregação de FAS que recruta o FADD, uma proteína adaptadora (CHINNAIYAN et al. 1995) que vincula-se à procaspase-8 para formar o complexo DISC (MEDEMA et al. 1997). Quando ocorre a oligomerização no DISC este se liga à procaspase-8 (SALVESEN e DIXIT, 1999), esse complexo (DISC-caspase-8) ativado induz a apoptose por dois caminhos diferentes, dependendo do tipo de célula (SCAFFIDI et al. 1998). Em células do tipo I, o complexo DISC é suficiente para a caspase-8 clivar e ativar caspases efetoras. Em células de tipo II o complexo DISC ativa quantidades menores de caspase-8 e requer amplificação do sinal apoptótico através da via mitocondrial de apoptose. A ativação deste circuito mitocondrial de amplificação é obtida através de clivagem de BID, um membro pró apoptótico da família Bcl-2. O BID é clivado, ao se ligar e ativar a Bax, ocorrendo a liberação de fatores apoptogênicos que atuam no citocromo-c da mitocôndria. Por sua vez, o citocromo-c ativa caspases efetoras via Apaf-1 e caspase 9 no apoptossomo (LI et al.; LUO et al 1998). Os inibidores de Top1 e Top2 podem ativar a via extrínseca, aumentando a expressão de FAS e FASL (CHATTERJEE et al.; SHAO et al 2001; CIUSANI et al 2002; MENENDEZ et al 2006). Pelo menos em alguns tipos de células esta transcrição é dependente da regulação da p53 (MULLER et al. 1998). A ligação de FASL com a FAS na superfície da célula define uma via autócrinaparácrina semelhante ao observado na ativação induzida por morte celular em linfócitos $\mathrm{T}$. No entanto, o papel da FASL na apoptose induzida por drogas provavelmente não é essencial, pois anticorpos antagonistas ou moléculas que impedem a interação com FAS e FASL não suprimem a apoptose (EISCHEN et al 1997; SHAO et al 2001). Drogas anticâncer podem induzir agregação de FAS na superfície das células tumorais na ausência de FASL (MICHEAU et al. 1997). Inibidores da topoisomerase induzem apoptose principalmente pela via intrínseca, via que pode ser reforçada, pelo menos em alguns tipos de células, pela via extrínseca transmembrana. 
Figura 1.3 - Ligação química do Etoposídeo a Topoisomerase II.

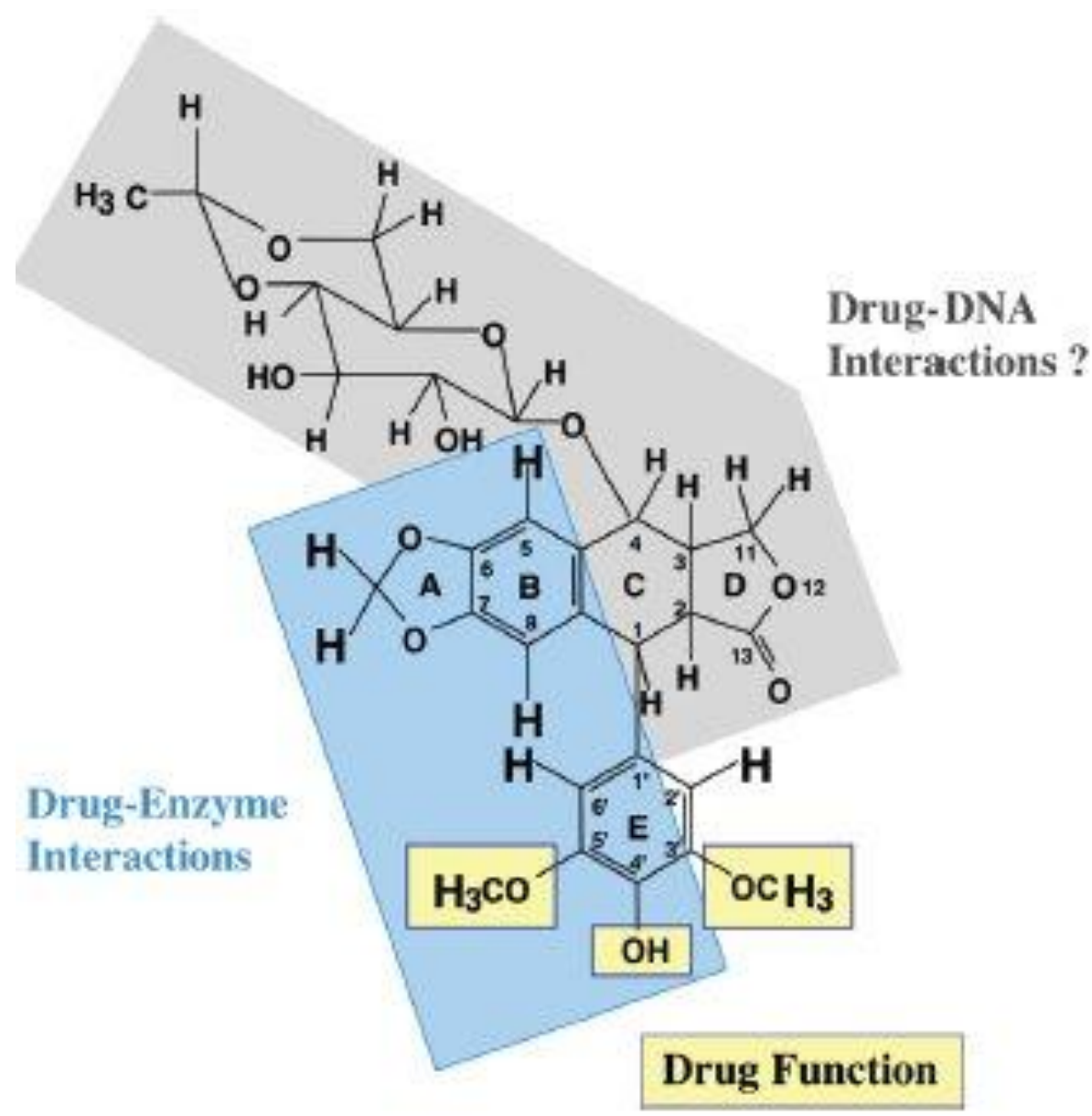

Resumo esquemático com a proposta da ligação química das subunidades do Etoposídeo que interagem com a enzima Top2. As Interações entre íons de Hidrogênio (H) e hidroxilas $(\mathrm{OH})$ da enzima foram obscurecidas pela formação de água e não são visualizadas. A região azul no Etoposídeo, incluindo partes A, B, e E (anel cíclico) são propostas para interagir com Top2 no complexo binário "droga-enzima". $O$ anel "E" e suas subunidades são destacados nas caixas amarelas e são importantes para a função de interação das drogas com a enzima, mas não parecem contribuir significativamente para a ligação química das moléculas. As interações entre o Etoposídeo e o DNA no complexo ternário (em cinza) são impulsionadas principalmente pelo anel-D, com contribuições adicionais do açúcar $\mathrm{C} 4$.

Fonte: BENDER et al, 2008; ROGOJINA et al, 2012)

\subsubsection{Mecanismos de ação e classificação das drogas antineoplásicas}

A maioria das drogas utilizadas na quimioterapia antineoplásica interfere de algum modo no mecanismo enzimático das células e suas vias metabólicas, e a melhor compreensão do ciclo celular normal levou à definição clara dos mecanismos de ação da 
maioria das drogas. Foi a partir dessa definição que Bruce e colaboradores (1969) classificaram os quimioterápicos conforme a sua atuação sobre o ciclo celular em:

- Ciclo-inespecíficos - Aqueles que atuam nas células que estão ou não no ciclo proliferativo, como, por exemplo, a mostarda nitrogenada.

- Ciclo-específico - Os quimioterápicos que atuam somente nas células que se encontram em proliferação, como é o caso da ciclofosfamida.

- Fase-específica - Aqueles que atuam em determinadas fases do ciclo celular, como, por exemplo, o Metotrexato (fase S), o Etoposídeo (fase G2) e a Vincristina (fase M).

\subsubsection{Drogas utilizadas no tratamento do câncer}

Os agentes antineoplásicos mais empregados no tratamento do câncer incluem os alquilantes polifuncionais, os antimetabólitos, os antibióticos antitumorais, os inibidores mitóticos e outros. Dentro do atual trabalho, além do inibidor da Top2 (Etoposídeo) vale destacar a classe dos Inibidores mitóticos.

Os inibidores mitóticos podem paralisar a mitose na metáfase, devido à sua ação sobre a proteína tubulina, formadora dos microtúbulos que constituem o fuso espiralar pelo qual migram os cromossomos. Deste modo os cromossomos, durante a metáfase, ficam impedidos de migrar ocorrendo a interrupção da divisão celular. Essa função tem sido útil na "sincronização" das células quando os inibidores mitóticos são combinados com agentes específicos da fase $\mathrm{S}$ do ciclo. Devido ao seu modo de ação específico, os inibidores mitóticos devem ser associados a outros agentes para maior efetividade da quimioterapia. Nesse grupo destacamos o Paclitaxel PCF, um agente que promove a agregação dos microtúbulos a partir dos dímeros de tubulina. O Paclitaxel estabiliza os microtúbulos prevenindo a despolimerização, resultando na inibição da dinâmica normal de reorganização do citoesqueleto. A indução de uma formação anormal no feixe de microtúbulos resulta em múltiplos ásteres durante a mitose, que por sua vez induz a apoptose. (ROWINSKY et al, 1990). 


\subsection{Campos Elétricos}

\subsubsection{Caracterização do Campo Elétrico}

O Campo Elétrico (CE) é uma perturbação no espaço que envolve uma carga elétrica, Q. Essa perturbação é percebida por outra carga, q, compartilhando esse mesmo espaço, através de uma força $F$ (força de $Q$ em q). Assim, a interação entre Q e q é mediada pelo $\mathrm{CE}$ cuja intensidade, $\mathrm{E}$, é definida como $\mathrm{E}=\mathrm{F} / \mathrm{q}$, ou seja, é a força exercida por unidade de carga. A unidade de medida de E é N/C (Newton por Coulomb) que é equivalente a $\mathrm{V} / \mathrm{m}$ (Volt por metro). O campo elétrico criado por Q existe independentemente de haver ou não cargas no seu entorno. Contudo, perceberemos a existência do campo somente quando colocarmos uma carga de prova (q) na região do espaço que envolve Q. O CE é uma grandeza física vetorial conforme exemplificado na Figura 1.4, que mostra os vetores campo elétrico gerados no espaço entre as placas de um capacitor (arranjo experimental utilizado neste trabalho). É interessante observar que um dipolo elétrico colocado na região em que o campo elétrico atua (entre as placas) sofrerá por parte deste uma ação equivalente a de um torque torsional. Esse torque fará o dipolo girar até que fique alinhado com o vetor campo elétrico, compelindo-o a movimentar-se somente na direção do vetor. Muitas moléculas de importância biológica, como água e proteínas constituem dipolos elétricos em seus

Figura 1.4 - Representação esquemática de um Campo Elétrico

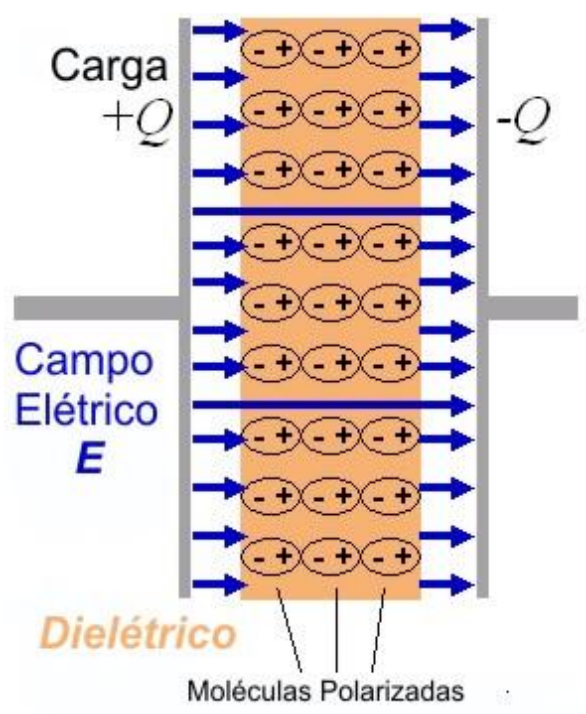

As setas representam os vetores de um campo elétrico. Um material contendo moléculas dipolares alinhadas na direção do $\mathrm{CE}$ é pictoricamente representado.

Fonte: Prónrio autor. estados naturais. Os íons são outros elementos de papel fundamental. Por serem cargas de sinal único, são arrastados pelo $\mathrm{CE}$ em movimento translacional na direção deste. A intensidade da força produzida pelo campo elétrico, por exemplo, é essencial para determinar se a configuração das proteínas ou estruturas celulares será alterada (REPACHOLI e GREENEBAUM, 1999). 


\subsection{2 $\quad \underline{\text { A Bioeletricidade e a Natureza Elétrica das Células }}$}

Em quase todos os sistemas biológicos dos organismos multicelulares, atividades fundamentais tais como: divisão, migração e diferenciação celular, ocorrem dentro de um meio extracelular onde estão presentes gradientes de tensão iônica, e consequentemente uma corrente elétrica, com uma atividade de horas ou mesmo dias (LEVIN, 2007; McCAIG et al, 2005; 2009). O gradiente de tensão iônica é formado principalmente por sinais elétricos, com origem nas variações de concentração dos íons no espaço circundante das células (na região extracelular). Essas variações espaciais decorrentes da presença de íons podem se formar: pelo funcionamento de bombas iônicas, vazamentos de íons de células individuais ou mesmo escape de íons através das camadas de membranas celulares (como as que realizam o transporte de íons epiteliais). Esse fluxo variável de íons estabelece os gradientes de tensão que são encontrados no meio extracelular e representam uma atividade sinalizadora para as funções fisiológicas acima citadas (LEVIN, 2007; McCAIG et al, 2005; 2009).

Os CEs fisiológicos superiores a $1 \mathrm{~V} / \mathrm{cm}$ ocorrem durante a cicatrização de feridas, no processo de morfogênese e crescimento de tumores, e esses mesmos campos foram simulados para induzir o sentido de migração de uma variedade de células (McCAIG, 2006). No entanto, o mecanismo pelo qual os CEs interferem diretamente no movimento de migração e divisão celular não é totalmente conhecido. Foi demonstrado que culturas de células endoteliais migram para a região do catodo de um campo elétrico exógeno aplicado na cultura (McCAIG 2009). O limite de ação do efeito do campo para que ocorra migração celular é de 1-2 V/cm, semelhante às forças do CE endógeno medidas in vivo. Além disso, a microscopia de fluorescência mostra que o agrupamento de projeções citoplasmaticas em direção ao catodo são ricas em filamentos de actina. Os estudos usando análise quantitativa de imagem mostram que o CE induz um aumento transitório de $80 \%$ na quantidade de filamentos de actina na célula. Comparando a distribuição de F-actina com a distribuição de proteína total, é possível determinar que a F-actina é assimetricamente distribuída no citoplasma, com uma concentração mais rica na região voltada ao catodo. É mais que evidente que os campos elétricos fisiológicos atuam diretamente na migração celular em resposta a um sinal intracelular. Esse sinal determina novas conexões no arranjo da actina no citoplasma, orientados em direção ao catodo (LI e KOLEGA, 2002). Com base nesses estudos e medidas realizadas in vivo, podemos afirmar que existem Campos Elétricos Estáticos (CEEs) que ocorrem naturalmente na célula, sendo que há uma grande variedade 
de células que respondem com uma migração direcionada em resposta ao efeito desses CEEs, comumente denominada galvanotaxia.

De forma similar à membrana celular, a mitocôndria cria um potencial de membrana através da diferença de íons entre a membrana interna e a intermediaria, formada pela ação das enzimas da cadeia de transporte de elétrons. Através da cadeia de transporte de elétrons a energia das moléculas de NADH e FADH2 é transferida para o oxigênio (O2) em várias etapas através de oxiredução (VOET, D; VOET, J; PRATT, 2006). Complexos de proteínas na membrana interna (NADH desidrogenase, citocromo c redutase, citocromo e oxidase c) realizam a transferência e liberação da energia bombeando os íons $\mathrm{H}^{+}$(prótons) para o espaço intermembranar. Com o aumento da concentração de prótons no espaço intermembranar há um forte gradiente eletroquímico, que é estabelecido através da seletividade da membrana interna aos íons. Os prótons podem voltar para a matriz através do complexo ATP sintase, e sua energia potencial é usada para sintetizar ATP a partir de ADP e fosfato inorgânico (Pi) (VOET, D; VOET, J; PRATT, 2006).

\subsection{Efeitos de Campos Elétricos e Magnéticos em Células Tumorais}

O envolvimento de sinais elétricos em células tumorais tem sido investigado de forma esporádica há cerca de 50 anos (AMBRÓSIO, 1956). É possível destacar duas abordagens, uma na ação dos CEs que têm sido recentemente aplicadas na investigação da biologia dos tumores e estudos clínicos, e outra abordagem no uso de campos magnéticos aplicados de forma combinada com outros agentes físicos.

\subsubsection{Uso de Corrente Alternada com Campos Elétricos de Alta Frequiência}

Em CEs com corrente alternada (CA) todas as moléculas polares estão sujeitas a torques que se alternam e, consequentemente, os fluxos iônicos fazem os dipolos moleculares oscilarem em torno da direção do torque. Devido à lenta cinética dos eventos bioelétricos, os CE de CA acima de $100 \mathrm{kHz}$ foram utilizados com o propósito de aquecimento, gerados pela agitação de moléculas, sem o propósito de realizar alterações biológicas reais. Esse procedimento se tornou base para o uso da eletroterapia no tratamento de tumores, porém pesquisas recentes estão modificando o propósito e a metodologia dessa abordagem. Estudos revelam que os CEs de CA (1 V/cm; com 100-300 $\mathrm{kHz}$ ) inibem o crescimento de células tumorais cultivadas in vitro, de melanomas sólidos de camundongo e, posteriormente, esse procedimento foi aplicado para tumores malignos 
de glioblastoma humano, realizados em aplicações médicas para estudos clínicos (KIRSON et al., 2004; 2007). O mecanismo propõem que o CE cause interferência na polimerização dos microtúbulos, levando a uma perturbação na formação do fuso mitótico que dificulta o processo de clivagem no final do ciclo mitótico (KIRSON et al. 2004).

\subsubsection{Campo Elétrico Pulsado de Alta Intensidade}

Em um experimento com melanomas sólidos de camundongo, foram utilizadas células cultivadas e expostas a CEs pulsados com pulsos ultracurtos (NUCCITELLI et al, 2006; 2009). Foram aplicados 400 pulsos $(40 \mathrm{kV} / \mathrm{cm})$ de 300ns nos núcleos das células tumorais que, como resultado, encolheram $50 \%$ em poucos minutos e cerca de $70 \%$ em 3 horas. Com esse tratamento obteve-se em muitos tumores a redução de $90 \%$ de células de melanoma no período de duas semanas. Um segundo tratamento posterior resultou, em muitos casos, na remissão completa do tumor. Essas respostas são notáveis para um CE com uma duração total de apenas algumas centenas de microssegundos. Devido ao tempo ínfimo seus efeitos não podem ser associados à ação térmica do $\mathrm{CE}$ pulsado. O estudo demonstra que estes pulsos ultracurtos atuaram no interior da célula e tiveram um efeito muito breve de permeabilizar as organelas intracelulares. Esse efeito visa causar uma rápida deformação eletromecânica no núcleo, danificando o DNA e consequentemente resultando na morte do tumor (NUCCITELLI et al,. 2006; 2009).

\subsubsection{Campos Magnéticos combinados com Radiação Eletromagnética}

Pesquisas envolvendo campos magnéticos apresentam paralelos com a pesquisa envolvendo Campos Elétricos, pois a fonte desses campos são cargas elétricas em movimento (correntes elétricas). Campos magnéticos exercem forças somente em cargas em movimento, e por isso são capazes de exercerem forças sobre íons em movimento em soluções, originando a indução de campos elétricos e correntes (indução magnética) (REPACHOLI e GREENEBAUM, 1999).

Pesquisas com o uso de campos magnéticos merecem ser citadas não somente pela sua associação indireta com Campos Elétricos, como pelo seu uso combinado com outros agentes, químicos e físicos, que induzem dano celular. Sua ação foi demonstrada no uso de campos magnéticos de freqüência extremamente baixa, interferindo no processo de reparo em microorganismos. Analisando plasmídeos de Escherichia coli, Koyama e outros (2005) 
observaram que células de E. coli expostas a Campos Magnéticos (com frequência de 5 mT - mili Tesla) imediatamente após irradiação com raios-X, tiveram aumento do número de mutações nos plasmídeos em relação ao controle não irradiado. Em um trabalho similar, Takashima e outros (2003) utilizaram células proficientes e deficientes de reparo de DNA em Saccharomices cerevisiae e com o uso de radiação ultravioleta inibiram o ciclo celular na fase $G_{1}$. Após o bloqueio do ciclo o processo foi revertido expondo as células a um Campo Magnético com frequência de $30 \mathrm{mT}$. Esse tipo de campo também foi utilizado para fins terapêuticos com intensidade de $15 \mathrm{mT}$ e amplitude e $120 \mathrm{Htz}$ de frequência, de forma isolada e combinada com os efeitos da radiação gama. Os experimentos foram realizados in vivo em camundongos nude xenoimplantados com células MDA-MB231, uma linhagem celular humana de câncer de mama (CAMERON et al., 2005). A terapia com radiação associada à exposição ao campo eletromagnético suprimiu o crescimento dos vasos sanguíneos e a repopulação do tumor após a irradiação, resultando em uma menor incidência de metástase tumoral.

\subsubsection{Campos Elétricos Estáticos de Origem Fisiológica}

Os tumores também têm sido investigados e tratados com a aplicação de um CEE que induz corrente semelhante à fisiológica. Os gradientes do potencial elétrico existente entre o espaço extracelular e tecidos cancerígenos podem ser medidos na superfície do tecido; essa medição tem uso clínico para o diagnóstico precoce do câncer de mama (CUZICK et al, 1998). Nessa região existe uma queda de tensão entre o tecido canceroso e o tecido normal, que pode ter sua origem na despolarização do potencial de membrana nas células tumorais (AMBROSE et al, 1956; BINGGELI e WEINSTEIN, 1986; WANG, 2004). A despolarização que ocorre nas regiões transepiteliais que circundam o tecido tumoral favorece a ocorrência de uma rápida metástase, diferente de um tecido sadio em que o epitélio é mais polarizado em relação ao meio. A polarização epitelial é mantida pelos tecidos normais circundantes, pois uma característica das células epiteliais é a de serem hiperpolarizadas em relação ao seu meio (FAUPEL et al, 1997). Considerando essas características McCaig e outros $(2006 ; 2009)$ têm procurado simular o CEE endógeno que há entre o tumor e o tecido normal, e com isso estudar métodos elétricos de prevenção do crescimento tumoral, dirigindo sua migração e controlando a metástase. Um novo estudo foi realizado na tentativa de explorar e identificar os fatores envolvidos na migração de células neoplásicas de um adenocarcinoma de pulmão. As células cultivadas migraram para a região do catodo dos CEEs de 3 V/cm (McCAIG et al, 2009). 
Tanto o ciclo celular quanto o mecanismo mitótico são influenciados por sinais oriundos do CEE fisiológico extracelular (SONG et al, 2002; WANG et al. 2003; 2005). Utilizar um CEE externo artificial pode ter um impacto profundo sobre o controle de tumores. Quando o CEE externo é aplicado sobre uma célula ocorre uma supressão na expressão da ciclina e um aumento da expressão da p27 KIP1 (um inibidor do CDK, do complexo ciclina). A conseqüência é a de as células não conseguem fazer a transição da fase S para a fase G1, impedindo a síntese de DNA e forçando o término antecipado do ciclo celular (WANG et al, 2003; 2005).

$\mathrm{O}$ efeito dos CEEs e das correntes elétricas no interior das células também afetam macroesturuturas celulares. Os filamentos que formam o citoesqueleto são polímeros de actina e microtúbulos que conduzem naturalmente a eletricidade, e por isso atuam como condutores elétricos com aproximadamente a mesma velocidade de condução, $20 \mathrm{~m} / \mathrm{s}$, do sinal da actina filamentosa encontrada em neurônios (TUSZYNSKI et al, 2004; PRIEL et al, 2006). Filamentos de actina e microtúbulos estão intimamente associados à estrutura e fixação da membrana plasmática e a receptores sensíveis de tensão aos canais iônicos da célula. A presença de filamentos íntegros de actina e microtúbulos é necessária para direcionar as respostas de correntes elétricas de forma análoga a uma fiação de um circuito elétrico (RAJNICEK et al, 2006). Considerando o sinal de transdução das etapas bioquímicas que acompanham a ativação de um neurotransmissor, ou de um receptor de fator de crescimento, muitos pesquisadores consideram a possibilidade de que haja uma ativação direta de uma corrente elétrica sinalizadora. Essa corrente elétrica é gerada no citoesqueleto e através deste conduzida até o núcleo, gerando eventos de comandos sinalizadores em paralelo às vias bioquímicas (McCAIG et al, 2009). A ligação física direta dos filamentos condutores da membrana plasmática ao núcleo, e seu papel na ativação seletiva dos genes, já foi evidenciada experimentalmente (MANIOTIS et al, 1997; NELSON et al, 2005.). Curiosamente, o DNA também realiza a condução de cargas elétricas em longas distâncias, sendo que as sequências de determinados pares de bases podem interromper o sinal, atuando como uma chave "liga/desliga" (MERINO et al, 2008). Com base nesses dados, não se deve limitar o papel dos CEEs endógenos nas ações de morfogênese ou em fatores de crescimento. A sinalização intracelular de funções metabólicas de natureza elétrica origina-se a partir da matriz extracelular, extendendo-se até o núcleo. Uma corrente é conduzida e modulada por estruturas biológicas que ativam eletricamente os filamentos condutores de actina dos microtúbulos e possivelmente atuando no DNA (McCAIG et al, 2009). McCaig e outros (2009) utilizam essas evidências 
para argumentarem que a fisiologia elétrica coexiste e interage com os processos bioquímicos e moleculares de sinalização, advertindo que as áreas de pesquisa que ignoram esse mecanismo também ignoram uma parte integrante fundamental de qualquer sistema biológico.

\subsection{A Sinalização Elétrica do DNA na Reparação Celular}

O controle de íons e moléculas na célula é mediado por proteínas com cargas polares, que essencialmente sofrem uma mudança conformacional para regular a entrada e saída de substâncias metabólicas, desempenhando um complexo papel nos canais iônicos celulares. A ação celular de polarização e despolarização da membrana nuclear, juntamente com o DNA associado, ativa comandos de moléculas hormonais, que por sua vez são responsáveis pela síntese e transcrição de proteínas. Esse efeito foi bem estudado na membrana nuclear, revelando que esta exibe a maior atividade elétrica da célula. Poros nucleares complexos reagem à despolarização de comandos eletrônicos gerados pelos sinais químicos hormonais e, assim, apresentam um efeito intimamente conectado com os CEE endógenos (MAZZANTI, et. al., 2001).

Com base em todas as propriedades ativadas por sinalização elétrica em uma célula eucariótica, podemos especular que há outros mecanismos de sinalização elétrica a serem desvendados e que estejam presentes na célula em suas propriedades mais básicas conservadas ao longo da evolução.

Uma das propriedades fundamentais das células é sua capacidade de reparação do dano do tipo DSB. Células eucariontes apresentam um mecanismo bioquímico complexo que é ativado quando ocorre algum tipo de estresse na molécula de DNA. Uma via de sinalização-transmissão é rapidamente ativada em resposta aos danos estruturais ou conformacionais no DNA, afetando o processo de transcrição de genes e interrompendo e a progressão do ciclo celular (BAKKENIST, e KASTAN, 2003; 2004).

Um dano do tipo DSB (assim como um dano de fita simples) desequilibra a distribuição das cargas em uma pequena região do DNA (de poucos pares de bases). Esse "desequilíbrio de cargas" gera um campo elétrico estático (endógeno). De acordo com um modelo biofísico e resultados experimentais (ARRUDA-NETO, et al., 2009; 2010), esse campo elétrico atua como um sinalizador para que as proteínas de reparo localizem e reconheçam o site do dano. Desta forma, grupos de poucos pares de bases poderiam ser localizados num universo de bilhões de pares de base (o genoma). Nesse mesmo cenário, um campo elétrico estático exógeno poderia reorientar as proteínas de reparo para longe 
dos danos, impedindo o reparo, conforme pictoricamente mostrado na figura 1.5, levando eventualmente à morte celular. De fato, com essas pesquisas realizadas com o uso de CEEs em procariotos e eucariotos, obtiveram-se evidências quanto à sinalização elétrica ente o DNA e proteínas visando a reparação celular.

Figura 1.5 - Ação do Campo Elétrico nas proteínas de reparo.
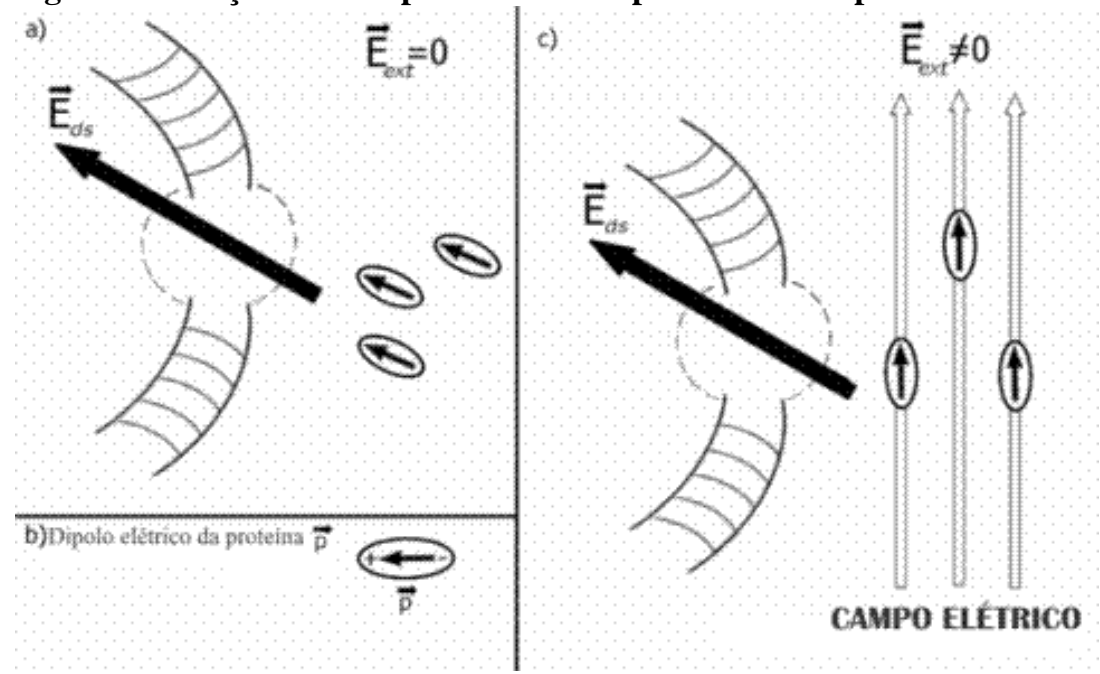

Representação pictórica do reconhecimento da dupla quebra (DNA) pelas proteínas de reparo. A) - Proteínas que apresentam seus momentos de dipolo $\vec{p}$ (representado em "b" com mais detalhes) orientados na direção do sítio danificado (dupla-quebra) pelo campo elétrico estático $\vec{E}_{d s}$. C) - Um CEE $\left(\mathbf{E}_{\text {ext }}\right)$, com maior intensidade que o $\mathbf{C E}$ endógeno $\left(E_{\mathrm{ds}}\right)$, pode reorientar o deslocamento das proteínas de reparo ao longo de sua direção, impedindo que estas alcancem o sítio danificado.

Fonte: ARRUDA-NETO et al., 2009; 2010.

É evidente o papel dos CEs endógenos na regulação de processos vitais essenciais como migração, proliferação e diferenciação em diversos tecidos (epitélios, axônios no cérebro e vários tipos de câncer). A sinalização celular mutuamente dependente de sinais químicos e gradientes elétricos é complexa e extremamente abrangente. É necessário examinar com mais atenção o papel da eletricidade endógena e as propriedades eletromagnéticas das estruturas celulares e suas funções biológicas ou não alcançaremos uma compreensão mais ampla dos processos vitais e da própria evolução. O estudo da sinalização elétrica endógena, em célula e tecidos, permite uma possibilidade de tratamento à formação de células neoplásicas e novas informações sobre o entendimento dos seus processos metabólicos. Pesquisas com a ação de CEs em células tumorais, e sua comparação com células de modelos saudáveis e associadas à formação do tumor, são fundamentais para o desenvolvimento de estudos mais avançados e um possível uso clínico dos efeitos dos CEs. 


\section{OBJETIVOS}




\subsection{GERAIS}

Estudar a ação de Campos Elétricos Estáticos no tratamento de tumores, de forma isolada e combinada com agentes antineoplásicos, utilizando uma linhagem celular tumoral e outra saudável como modelos de estudo.

\subsection{ESPECÍFICOS}

1. Implementar procedimentos de análise que possibilitem determinar os efeitos da ação do Campo Elétrico Estático em células melanocíticas B16F10 e normais de fibroblastos FN1 na morfologia, citotoxicidade e crescimento celular.

2. Análise do efeito isolado do Campo Elétrico Estático na indução de tipos de morte celular e alterações no potencial de membrana mitocondrial em função do tempo.

3. Estudo da citoxicicidade celular à exposição combinada do Campo Elétrico Estático com os quimioterápicos Etoposídeo e Paclitaxel em função da concentração.

4. Caracterizar e quantificar a mortalidade celular e atividade mitocondrial dos efeitos combinados do Etoposídeo com um Campo Elétrico Estático em função do tempo.

5. Identificar possíveis condições e mecanismos celulares que sejam afetados pelo uso combinado de um agente químico ou físico indutor de danos na fita dupla do DNA quando associados a Campos Elétricos Estáticos.

6. Propiciar subsídios direcionados ao uso de Campos Elétricos Estáticos e sua eficácia como agente quimiosensibilizador no tratamento tumoral. 
3 MATERIAL E MÉTODOS 
3.1 Organograma dos Experimentos Realizados
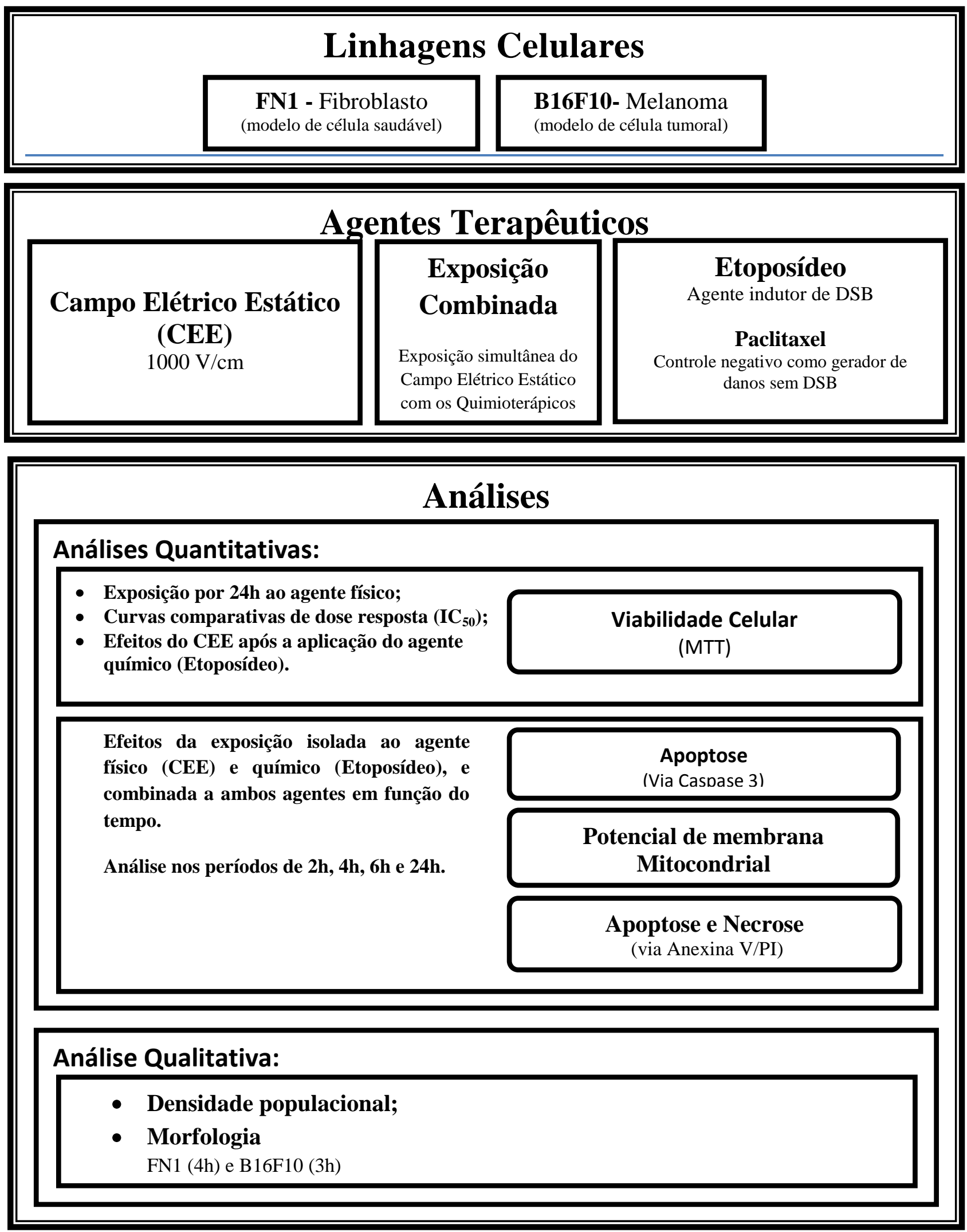


\subsection{Linhagens Celulares e Reagentes}

\subsubsection{Melanoma Murino B16F10}

A linhagem celular é uma variante F10 do melanoma murino B16. Seu cultivo em laboratório apresenta rápido crescimento e é facilmente transplantada em camundongos C57BL16, com alta capacidade de disseminação metastática, pré estabelecidas e comercializadas pela ATCC. (American Type Culture Collection)

\subsubsection{Fibroblasto humano FN1}

FN1 é uma linhagem de células de fibroblastos clonogênicos humanos normais, cultivados e cedidas pelo Professor Durvanei Augusto Maria - CAPPesq HCFMUSP $\mathrm{n}^{\circ} 921 / 06$.

Todas as linhagens foram cedidas pelo Prof. Dr. Durvanei Augusto Maria, do Instituto Butantan.

\subsubsection{Reagentes e Soluções}

\subsubsection{Meio de cultura RPMI- 1640}

Composição: sais inorgânicos, aminoácidos, vitaminas, outros componentes (glicose, glutamina e vermelho de formol). (Sigma Chemical, Av. das Nações Unidas 23043, Vila Almeida, CEP 04795-100 São Paulo, SP (Brazil))

\subsubsection{Solução de Congelamento}

$90 \%$ de Soro fetal bovino

10\% de DMSO. (Sigma Chemical)

\subsubsection{Solução de MTT}

$80 \%$ de meio de cultura completo

20\% de MTT 5mg/mL (Sigma Chemical) .

\subsubsection{Tripsina}


Solução com 0,25\% de tripsina-EDTA (2,5 g tripsina suína e 0,2 g EDTA 4NA), $100 \mathrm{ml}$ (Sigma Chemical)

\subsubsection{Solução tampão Fac's Flow}

Solução de "Fluorescence activated cell sorter (Fac`s)", da Sigma Chemical, com 4\% de paraformaldeído, utilizados para fixação e conservação das células. Para análise no citometro de fluxo as células eram ressuspensas somente em Fac`s Flow.

\subsubsection{Vermelho Neutro}

Vermelho neutro (3-amino-7-dimetilamino-2-metil-fenazina cloridrato) da Sigma Chemical

\subsubsection{Quimioterápicos}

Etoposídeo VP-16

Paclitaxel PCF

Os quimioterápicos foram diluídos em solução fisiológica estéril de $0,9 \%$ para obter as concentrações desejadas.

\subsection{Metodologia}

\subsubsection{Cultivo das Células}

As células armazenadas e congeladas foram retiradas do nitrogênio liquido e colocada em banho-maria $\left(37^{\circ}\right)$ até que a maior parte do material estar descongelado. Rapidamente o conteúdo do criotubo foi transferido para um tubo de centrifuga juntamente com $2 \mathrm{ml}$ de meio de cultura RPMI. Centrifugou-se por $10 \mathrm{~min}, 1500$ RPM, descartou-se o sobrenadante e foi feita a ressuspensão do pellet em $1 \mathrm{~mL}$ de meio de cultura completo. Esta solução foi adicionada a uma garrafa de cultura pequena $\left(25 \mathrm{~cm}^{2}\right) \mathrm{com} 4 \mathrm{~mL}$ de meio de cultura completo.

As culturas celulares cresceram em meio de cultura RPMI 1640 suplementado com $10 \%$ de soro fetal bovino, e $0,1 \%$ garamicina, (80 mg - Schering-Plough). A cultura celular 
foi incubada a $37^{\circ} \mathrm{C}$ em atmosfera úmida de $5 \%$ de $\mathrm{CO}_{2} . \mathrm{O}$ meio de cultura foi trocado rotineiramente a cada 1-2 dias. Ambas as linhagens estudadas apresentam ciclos de cultivo bem próximos.

\subsubsection{Cultura para os Experimentos}

As células da linhagem tumoral de melanoma murino B16F10 e fibroblastos humanos (FN1) foram cultivadas em frascos de cultura de $75 \mathrm{~cm}^{2}$ em meio de cultura As células aderidas foram desprendidas com tripsina incubando por 3 minutos a temperatura de $37^{\circ} \mathrm{C}$, e transferidas para os tubos de centrífuga onde foram centrifugadas duas vezes, ressuspensas em meio de cultura onde a concentração celular pode ser ajustada para $5 \times 10^{5}$ células/mL via contagem em câmera de Mallassez. Após este procedimento, as células foram adicionadas em placas de petri de $35 \mathrm{~mm}$, com volume total de $1 \mathrm{~mL}$ (para os experimentos de coloração e citometria de fluxo) e $100 \mu \mathrm{L}$ nas placas de 96 orifícios (para os ensaios de MTT), por 24 horas para obter adesão e confluência celular.

Estabelecida a concentração celular, com células em suspensão foi adicionado nas placas $1 \mathrm{~mL}$ de solução nas placas de Petri de $35 \mathrm{~mm}$ (para os experimentos de coloração e citometria de fluxo) e com $100 \mu \mathrm{L}$ nas placas de acrílico de 96 furos (para os ensaios de MTT), por 24 horas para obter adesão e confluência celular

\subsubsection{Exposições ao Campo Elétrico Estático}

O sistema de tratamento com campo elétrico estático (CEE) foi desenvolvido usando uma fonte de alta voltagem que opera entre 0 e $2 \mathrm{kV}$. Esta fonte foi conectada através de dois eletrodos a um capacitor de placas circulares paralelas de alumínio $\left(25 \mathrm{~cm}^{2} \mathrm{de}\right.$ diâmetro) com um intervalo de $2 \mathrm{~cm}$ entre as placas previamente esterilizadas com álcool $70 \%$, dispostas verticalmente as placas de cultura e conectadas a um transformador regulador de voltagem.

A intensidade do campo elétrico aplicado foi padronizada em $1000 \mathrm{~V} / \mathrm{cm}$, após a adição das placas com o cultivo celular entre as placas do capacitor. Em todos os casos o tratamento foi realizado dentro da estufa de crescimento, isolada por suporte plástico previamente esterilizado, mantida em condições ambientais padronizadas da estufa de crescimento.

\subsubsection{Avaliação da Citotoxicidade - via MTT- do CEE nas Células}


Os testes de viabilidade e proliferação celular foram determinados através do teste colorimétrico 3 -(4,5-dimetiltiazol-2-1) 2,5-difenil tetrazolio brometo (MTT) em testes de 24 horas de crescimento na cultura para ambas as linhagens estudadas. Foram estabelecidos dois grupos experimentais:

a) Controle: cultivado paralelamente ao experimento, renovando-se o meio de cultura ao mesmo tempo que as outras variavies. $\mathrm{O}$ controle esra mantido nas mesmas condições experiemntais dos demais tratamentos (estufa de cultura), sem qualquer aplicação de agnetes quimicos ou fiscios;

b) Campo Elétrico Estático: Células cultivadas nas mesmas condiçõess e paralelamente ao controle, expostas entre as palcas do capacitor com o CEE de $1000 \mathrm{~V} / \mathrm{cm}$.

Após 24 horas do experimento nas condições citadas o sobrenadante foi descartado e foram adicionados $100 \mu \mathrm{L}$ de solução de MTT às células, e estas incubadas por 3 horas em estufa contendo $5 \%$ de $\mathrm{C}_{2}$ a $37^{\circ} \mathrm{C}$. Após este período, o meio foi removido e acrescentou-se $100 \mu \mathrm{L}$ de metanol absoluto para dissolver os cristais de formazan formados e precipitados. A quantificação da absorbância foi feita em leitor de ELISA em comprimento de onda de $540 \mathrm{~nm}$. Os valores obtidos foram realizados em quadruplicata (minimamente), sendo o resultado final a média dos mesmos. $\mathrm{O}$ valor de absorbância nas células não expostas ao CEE foi estabelecido em 100\%, utilizando esse parâmetro para cada ensaio com MTT, permitindo padronizar e comparar os valores obtidos pela absorbância. Foi calculado o desvio padrão entre as réplicas das amostras para determinar o número médio percentual das células afetadas pelo CEE e posteriormente à análise de variância entre seis experimentos realizados para determinar o valor final dos efeitos isolados do Campo Elétrico nas células.

Com procedimento similar ao descrito com o CEE isolado, células cultivadas e aderidas em placas de 96 orifícios de cada linhagem foram dividas em dois grupos. Cada grupo recebeu concentrações de 1,70;0,85;0,42;0,21;0,1 mmol de Etoposídeo, com quatro a oito replicas para cada concentração. As concentrações foram estabelecidas pela análise do valor do $\mathrm{IC}_{50}$ (indice celular de 50\%), determinado pelo ajuste dos resultados em uma reta de tendencia (gráfico 4.9). Imediatamente após a aplicação do quimioterápico os dois grupos experimentais foram deixados na estufa de crescimento em paralelo, sendo um 
dos grupos exposto ao CEE. Ao todo foram realizados quatro ensaios, sendo os resultados gráficos determinados pela média com o erro da variância, de forma análoga ao experimento anterior.

Para determinar os efeitos do CEE em função de outro agente quimico, que não gerasse danos do tipo DSB, foi escolhido o quimioterápico Paclitaxel PCF, como um "controle negativo". Seu uso bem dissiminado no tratamento em melanoma e seu efeito inibidor na tubulina, atuando pricnipalmente na fase de divisão celular, permitiu estabelecer paralelos com os resutlados obtidos com o Etoposídeo. Os experimentos envolvendo o Paclitaxel foram realizados com a mesma metodologia, sendo o resultado final a média três repetições experimentais, com as concentrações de: 2,$34 ; 1,17 ; 0,59$; 0,29; 0,15 mmol de Paclitaxel PCF nos poços com células aderidas. Os valores das concentrações do Paclitaxel foram detemrinados pela mesma metodologia (via $\mathrm{IC}_{50}$ do ajuste da reta de tendência) do Etoposídeo.

Para determinar a influência do CEE nos momentos inciais de exposição ao Etoposídeo, foram realizados dois ensaios com intervalos entre a aplicação do quimioterápcio e exposição ao CEE. Ocorreram intervalos para a exposição combinada de: 0; 1 e 2 horas entre a aplicação do quimioterápico e a posterior exposição do CEE. Nesse procedimento as culturas celulares com Etoposídeo foram deixadas na estufa de crescimento pelo intervalo determinado até serem expostas ao CEE.

\subsubsection{Análises via Citometria de Fluxo}

A citometria de fluxo é utilizada para a identificação de tipos celulares em suspensão, promovendo a identificação e quantificação de células pelo tamanho, granulosidade e intensidade de fluorescência (ROTT et al., 1999). A avaliação do tamanho relativo da célula permite sua classificação (GRINDEM, 1996). A avaliação da intensidade de fluorescência ocorre para a detecção de receptores de superfície diferentes, marcados com anticorpos monoclonais específicos ligados a compostos fluorescentes (GRINDEM, 1996). A avaliação de receptores intracelulares (nuclear e citoplasmático) por citometria de fluxo é essencial durante o estudo de marcadores de diferenciação ou de vias de sinalização, como por exemplo, a fosforilação de kinases da via apoptótica (KOESTER; BOLTON, 2000).

Para realizar o experimento foram cultivadas em placas de Petri de $35 \mathrm{~mm} 1 \mathrm{~mL}$ da suspensão de B16F10 ou FN1 na concentração de 1 x $10^{6}$ células/mL e incubadas em 
estufa de cultura a $37^{\circ} \mathrm{C}$ e $5 \%$ de $\mathrm{CO}_{2}$, durante $24 \mathrm{~h}$. Após este período o sobrenadante foi descartado e as placas divididas em quatro grupos, sendo:

a) Controle: grupo que obteve o meio de cultura renovado e novamente incubado na estufa de cultura.

b) Etoposídeo: aplicou-se uma solução de 0,17 mmol de Etoposídeo diluído em solução fisiológica de $0,9 \%$. Essa concentração foi estabelecida com base nos resutlado de MTT para se obter $20 \%$ de mortalidade celular que pudesse ser carcatrizada eplos marcadores.

c) Campo Elétrico Estático: após a renovação do meio de cultura, as células aderidas na placa de Petri foram posicionadas entre as placas do capacitor, e submetidas à ação do campo elétrico de $1000 \mathrm{~V} / \mathrm{cm}$.

d) Etoposídeo com Campo Elétrico: Aplicados o Etoposídeo de 0,17 mmol, as células foram condicionadas entre as placas do capacitor de forma idêntica ao item "c" com a solução de Etoposídeo nas mesmas condições do item "b".

Os quatro grupos experimentais foram tratados e incubados na estufa de crescimento simultaneamente, sendo retiradas amostras em duplicatas de cada grupo, nos períodos de 2 , 4, 6 e 24 horas após o início de exposição ao quimioterápico e Campo elétrico. Quando coletado o conteúdo do sobrenadante foi descartado e as células tripsinizadas, ressuspensas e centrifugadas para formação do pellet. Após as amostras serem centrifugadas, o sobrenadante foi descartado com bomba de vácuo e o conteúdo lavado duas vezes com tampão Fac`s. Por fim, cada amostra coletada de todos os períodos analisados foram ressuspensas em solução tampão fac's flow e conservadas a temperatura de $4^{\circ}$ até o dia da análise. Todos os ensaios experimentais foram repetidos e realizados isoladamente para cada linhagem trabalhada.

\subsubsection{Caspase 3}

As alíquotas com $100 \mu \mathrm{L}$ das suspensões celulares foram incubadas por 1 hora, à $4^{\circ} \mathrm{C}$, com $1 \mu \mathrm{g}$ de anticorpo específico para caspase 3 (FITC) e $10 \mu \mathrm{L}$ de Triton X-100 $0,1 \%$ para permeabilizar a membrana celular. Após este período as células foram centrifugadas por 10 minutos á 1500 RPM e lavadas com PBS gelado. O sobrenadante foi desprezado e o pellet ressuspenso em PBS contendo $0,1 \%$ de paraformaldeído. 
A leitura e análise da expressão do marcador foi realizada em citômetro de fluxo FACScalibur (BD) em intensidade de fluorescência FL-1. (marcados com FITC)

\subsubsection{Rodamina 123}

No momento da análise, as amostras foram centrifugadas á $1800 \mathrm{rpm}$ por 10 minutos, o sobrenadante foi descartado, e foram adicionados $5 \mu \mathrm{L}$ de Rodamina 123 $(5 \mathrm{mg} / \mathrm{mL})$ em cada tubo. As amostras foram colocadas em estufa de $\mathrm{CO}_{2}(5 \%)$ á $37^{\circ} \mathrm{C}$ por 30 minutos. Após este período, os tubos foram centrifugados, o sobrenadante foi descartado e o pellet foi ressuspenso em $100 \mu \mathrm{L}$ de tampão Fac's Flow.

A leitura e análise da marcação da Rodamina 123 nas células foi realizada em citômetro de fluxo FACScalibur (BD) em intensidade de fluorescência FL-1.

\subsubsection{Anexina-V e PI}

As células armazenadas foram lavadas $2 \mathrm{x}$ em tampão Fac's Flow a $4^{\circ} \mathrm{C}$, ressuspensas em $100 \mu \mathrm{L}$, e incubadas por 30 minutos com $1 \mu \mathrm{g}$ de anexina V-FITC (SantaCruz) e $5 \mu \mathrm{L}$ de solução de iodeto de propídio $18 \mu \mathrm{g} / \mathrm{mL}$ (Sigma Chemical).

Células que expressam a fosfatidilserina na face exterior das membranas celulares ligam a anexina $\mathrm{V}$ e as células com uma membrana celular comprometida permitem que o Iodeto de propídio ligue-se ao DNA celular. As células resultantes, quando analisadas imediatamente por citometria de fluxo, apresentam quatro potenciais populações celulares: as células vivas não marcadas com nenhum fluorocromo, células necróticas marcadas somente com PI, células que se encontram no início apoptose marcadas somente com o reagente FITC da anexina V e quando há a dupla marcação (iodeto de propídio e Anexina V) há apoptose em fase tardia. Canais de fluorescência: FITC (FL-1) e PI (FL-2).

\subsubsection{Análise Colorimétrica}

De forma similar ao procedimento de em citometria de fluxo, as culturas de B16F10 e FN1 foram realizadas em placas de petri de $35 \mathrm{~mm}$ em 4 grupos experimentais, utilizando a concentração de $0,35 \mathrm{mmol}$ de Etoposídeo nos grupos com quimioterápicos. A concentração foi determinada com o intuito de obter $60 \%$ e $30 \%$ de redução de viabilidade, respectivamente para os resutlados sem e com o CEE (baseado nos valores medidos via 
MTT), possibilitado diferenciar significativamente o resultado final. As amostras foram coletadas com 4 horas de exposição para FN1, e 3 horas para B16F10 (devido ao seu metabolismo mais intenso, os resultados são visiveis com menor tempo de exposição). Nesses períodos selecionados a maior parte dos efeitos do Etoposídeo são perceptiveis na cultura. Após esse periodo o sobrenadante foi descartado e foram aplicados $1 \mathrm{~mL}$ de corante Vermelho Neutro por 5 min. O excesso do reagente foi retirado com uma pipeta Pasteur e as placas de petri foram armazenadas em ambiente seco por 24 horas antes de serem fotografadas.

\subsection{Análise Estatística dos Resultados}

A concentração dos quimioterápicos utilizada foi determinada pelo Índice Celular $50 \%\left(\mathrm{IC}_{50}\right)$ após a padronização da curva de tendência em uma reta (nas amostras expostas isoladamente ao quimioterápico) e uma curva exponencial (no caso das células expostas de forma combinada ao quimioterápico e CEE), possibilitando a construção das curvas de dose resposta. Os resultados médios foram calculados estabelecendo-se uma barra de erro baseado na variância entre as repetições.

As análises realizadas através da citometria de fluxo foram examinadas e quantificadas com o programa WinMID 2.8. A análise das amostras marcadas com Rodamina 123 foi quantificada com o programa FlowJo 7.6.5. Os resultados foram estabelecidos pela média com percentual de erro determinado pela variância entre as réplicas.

O programa "Origins 6.0" foi utilizado para levantar os gráficos e determinar a significância dos resultados pelo teste "ANOVA", sendo considerados os resultados significativos $\geq 0,05$. 
4 RESULTADOS 


\subsection{Análises qualitativas via coloração com Vermelho Neutro}

\subsubsection{Amostras Coradas de Células de Melanoma B16F10}

Figura 4.1 - Fotografia das placas de petri com células B16F10.

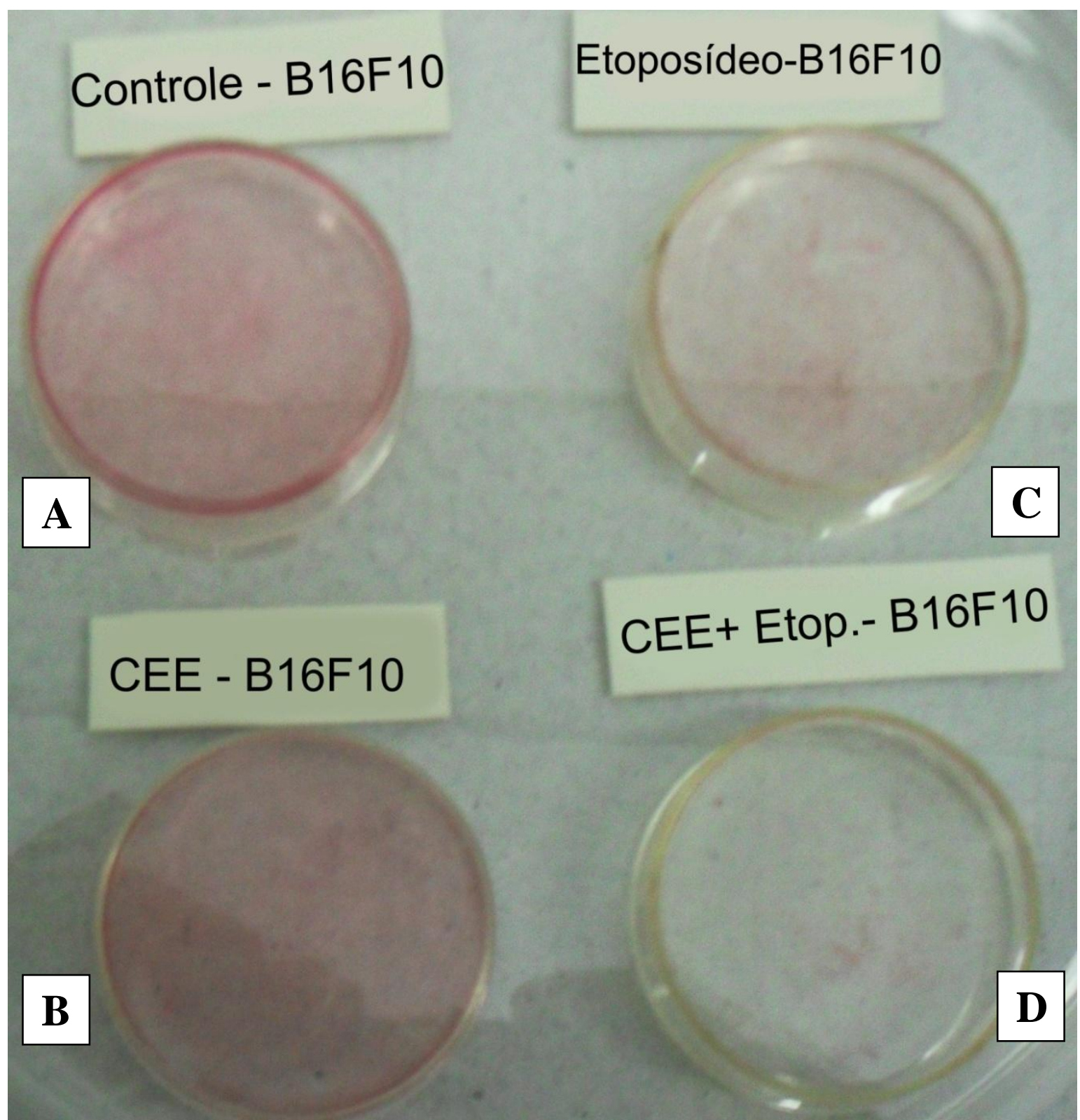

Fotografia das placas de petri com células de melanoma murino B16F10 aderidas e coradas com vermelho neutro. A imagem sofreu uma pequena alteração digital nas etiquetas identificando as placas.

Fonte: Próprio autor.

Na figura 4.1 encontram-se imagens das placas de petri $(35 \mathrm{~mm})$ com células de melanoma murino B16F10 aderidas. As amostras foram coletadas e registradas após 3 horas da aplicação de 0,35 mmol do quimioterápico Etoposídeo (C e D) e aplicação do Campo Elétrico Estático (CEE) de 1000 V/cm (B e D).

Os resultados localizados à esquerda da imagem referem-se às amostras sem o 
quimioterápico (A) e apenas com exposição ao CEE (B), onde não são encontradas diferenças perceptíveis na concentração celular aderida a placa de petri. À direita da imagem se encontram as placas com aplicação do Etoposídeo (C) e combinados ao CEE (D). Nessa imagem é possível detectar uma significativa redução da população celular entre a placa "C" e "D".

Figura 4.2 - Fotografia das placas de petri com células de melanoma murino B16F10 aderidas e coradas com vermelho neutro.

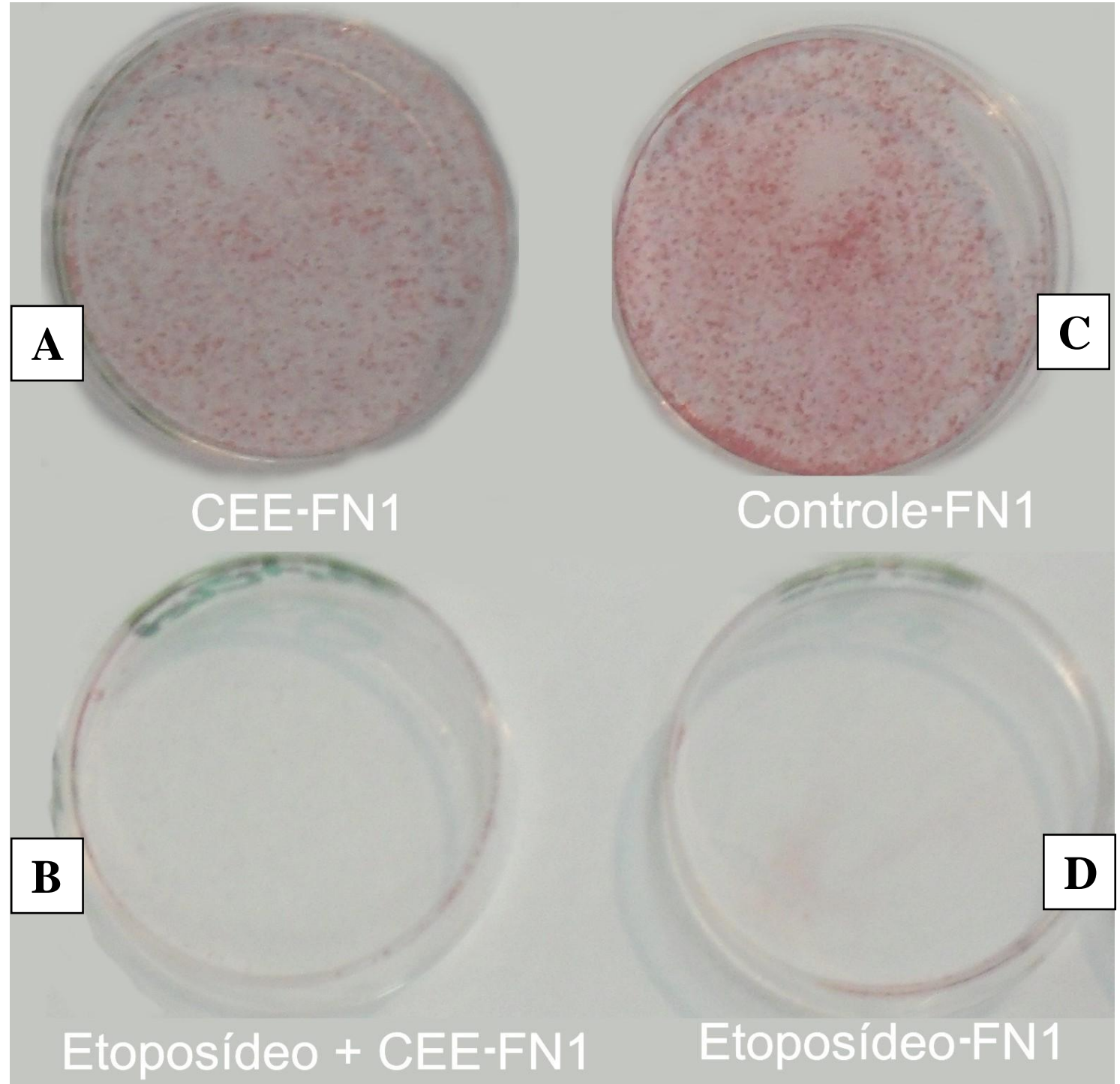

Imagens das placas de petri com células humanas de fibroblasto FN1 e coradas com vermelho neutro. A imagem sofreu uma alteração digital para enquadrar todas as placas no mesmo campo visual. Foram realizados retoques na foto (ajuste do brilho e acréscimo das legendas).

Fonte: Próprio autor.

Similarmente à imagem da figura anterior (4.1), a figura 4.2 mostra as placas de petri com células de fibroblastos FN1, revelando as diferenças entre as densidades populacionais das células tratadas com o quimioterápico Etoposídeo (B e D), das células 
controle sem tratamento (A) e as expostas ao CEE (B). As concentrações de Etoposídeo e intensidade na voltagem do CEE são iguais ao caso anterior, com período de exposição de 4 horas de incubação para todos os grupos experimentais.

A análise das placas presentes na figura 4.2 não permite identificar alguma alteração significativa na densidade populacional, entre as células do controle e aquelas expostas ao CEE. Por outro lado, como ocorre nas células melanocíticas, é possível identificar uma redução na densidade populacional no tratamento combinado de CEE com Etoposídeo em relação ao tratamento com o quimioterápico isoladamente. $\mathrm{Na}$ comparação entre as imagens B e D da figura 4.2, a população aderida do tratamento combinado (B) praticamente desaparece, em contraste com a placa com o Etoposídeo isoladamente (D). Este ultimo apresenta uma fraca, porém visível, população aderida, indicando uma sobrevivência maior ao Etoposídeo isoladamente.

A figura 4.3 mostra a população de células de B16F10 coradas e sem tratamento (A), e expostas ao Etoposídeo (B). É possivel identificar zonas de proliferação celular incluindo uma intensa presença de vesículas em ambos os grupos. Nenhuma diferença morfologica ou na divisão celular foi identificada entre o controle e as células expostas ao CEE. Do mesmo modo que a população de melanoma, a população de fibroblastos FN1 (figura 4.6) não apresentou qualquer diferença visível entre o grupo controle e o exposto unicamente ao CEE.

As imagens (figura 4.3.B e 4.5) permitem visualizar células com retração da membrana citoplasmática e intensa atividade vesicular ao redor do nucleo fragmentado (identificando sinais de apoptose - setas pretas). Também são visíveis células com o citoplasma extendido, caracterizando rompimento da membrana celular e indicação de necrose (setas brancas). Analogamente às condições de controle sem o quimioterápico, nenhuma alteração morfologica pode ser identificada entre as amostras celulares submetidas ao Etoposídeo e em sua ação conjunta com o CEE. 
Figura 4.3 - Imagem do grupo controle de células B16F10 e células expostas ao quimioterápico Etoposídeo.

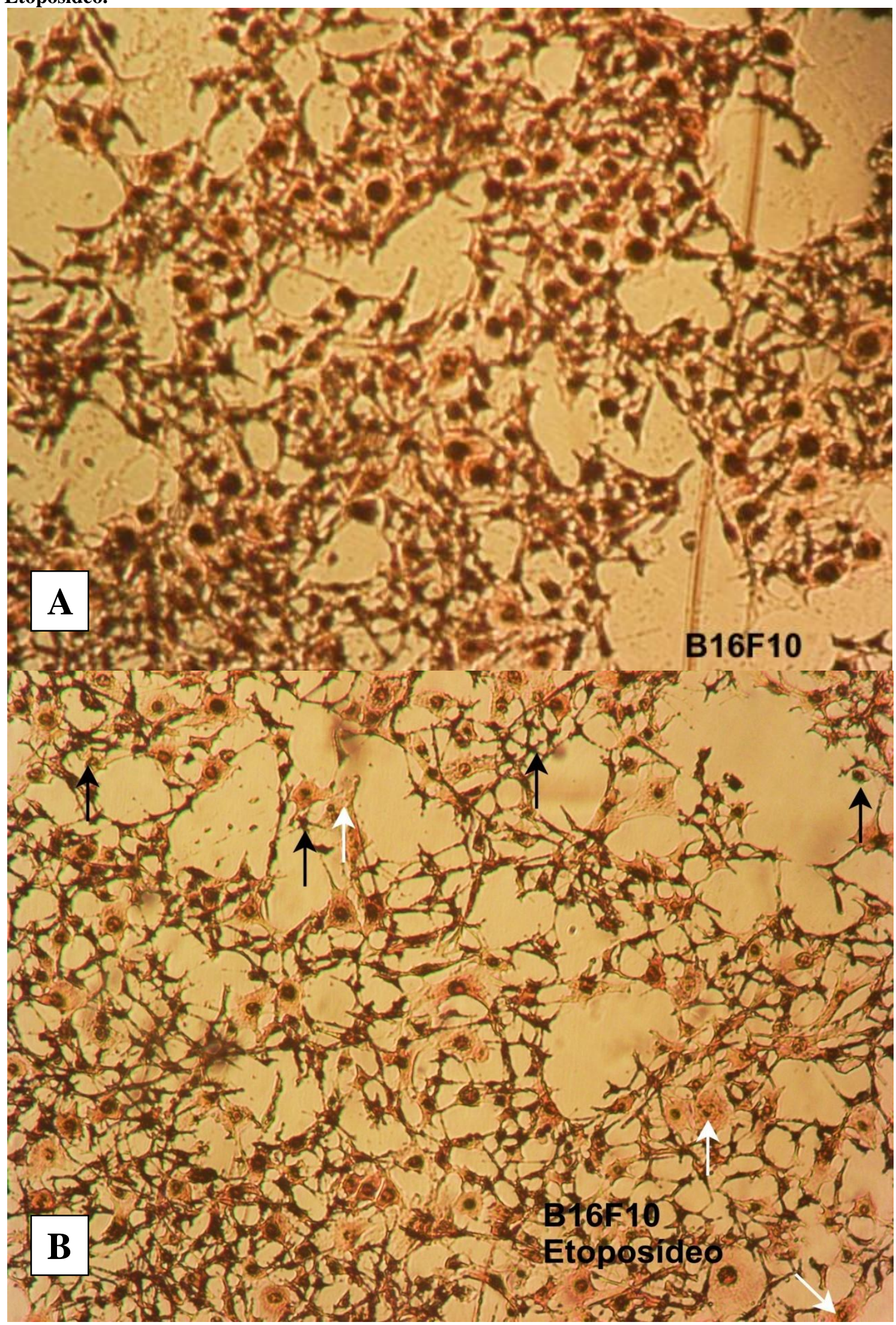

Imagem comparativa do grupo controle de células melanocíticas B16F10 (A) e os efeitos do quimioterápico Etoposídeo, com concentração de $0,35 \mathrm{mmol}(\mathrm{B})$, com indícios de células necróticas e apoptóticas. Imagem obtida no microscópio de inversão. Aumento de 160X.

Fonte: Próprio autor. 
Figura 4.4 - Imagem do grupo controle de células B16F10 e células expostas ao Campo Elétrico Estático.

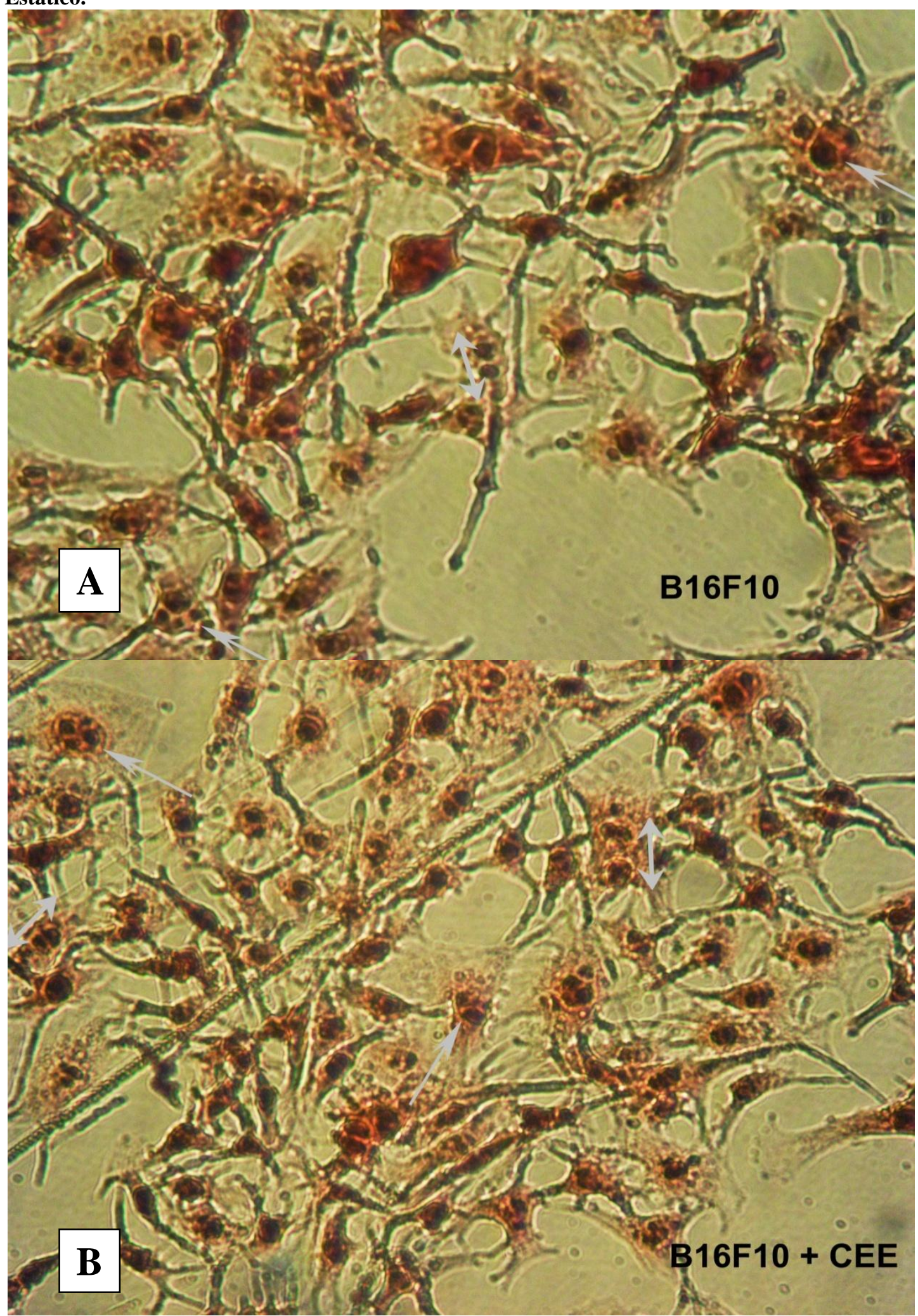

Imagem registrada via microscópio de inversão com aumento ótico de 160x seguido de aumento digital de 3x. A imagem permite visualizar os detalhes da morfologia das células tumorais B16F10 (A) e a ausência de efeitos na exposição ao CEE (B). As setas cinza representam células multinucleadas, características de tumores, e as setas duplas indicam possível mitose. Aumento de $160 X$ com zoom digital de $3 x$. Fonte: Próprio autor. 
Figura 4.5 - Imagem das células B16F10 expostas ao Campo Elétrico Estático e ao quimioterápico Etoposídeo.

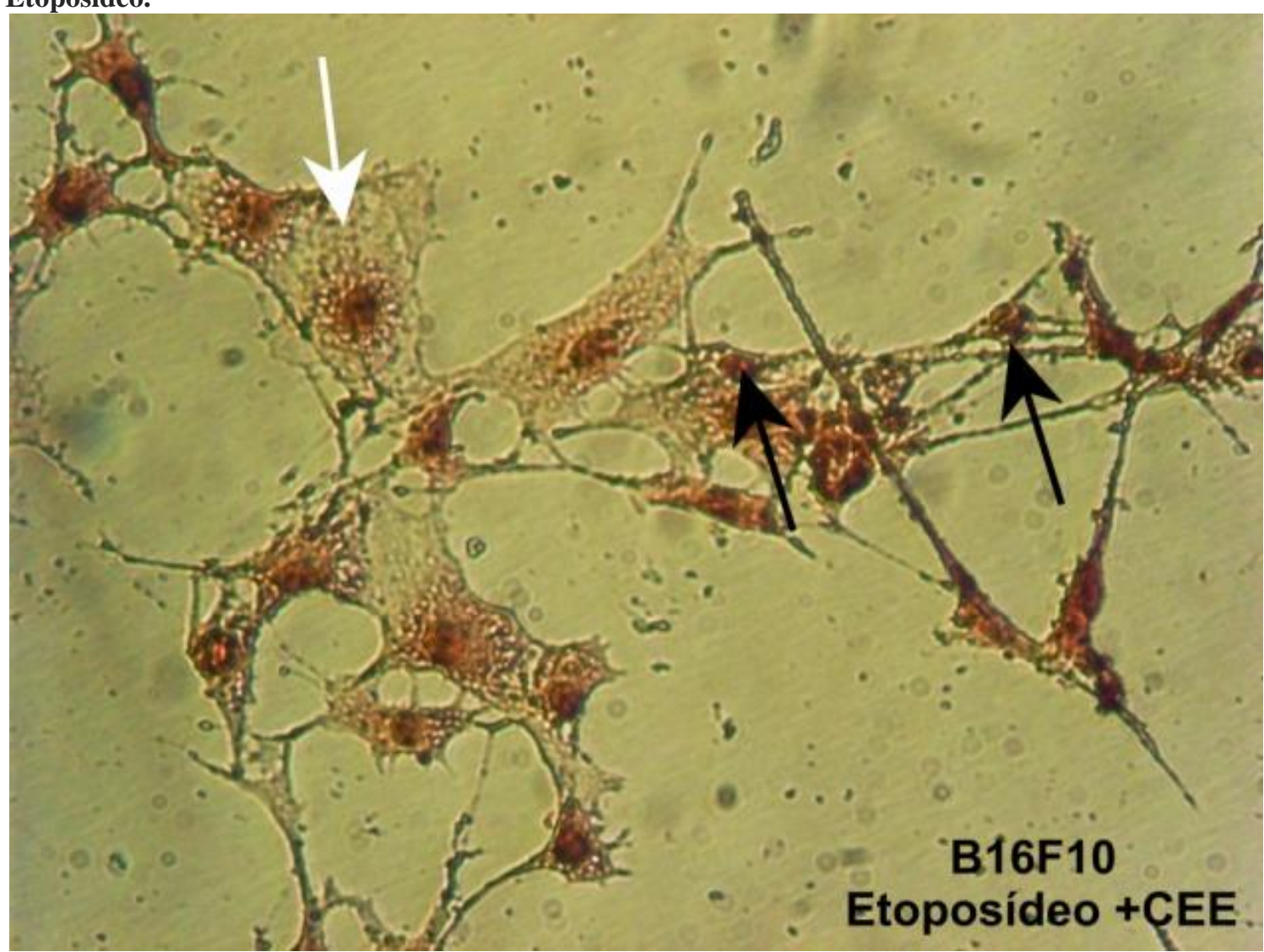

Imagem obtida via microscópio de inversão, com aumento de $160 \mathrm{X}$ e zoom digital posterior de 3x. A imagem permite visualizar os detalhes da morfologia das células tumorais B16F10 aos efeitos combinados do Etoposídeo com o CEE. O resultado é muito similar à figura 4.3 B, destacando-se região de células necrosadas (setas brancas) e apoptóticas com detalhes para a formação de vesículas ao redor do núcleo. Aumento de 160X com zoom digital de 3x.

Fonte: Próprio autor. 
Figura 4.6 - Imagem do grupo controle de células FN1 e células expostas ao Campo Elétrico Estático.

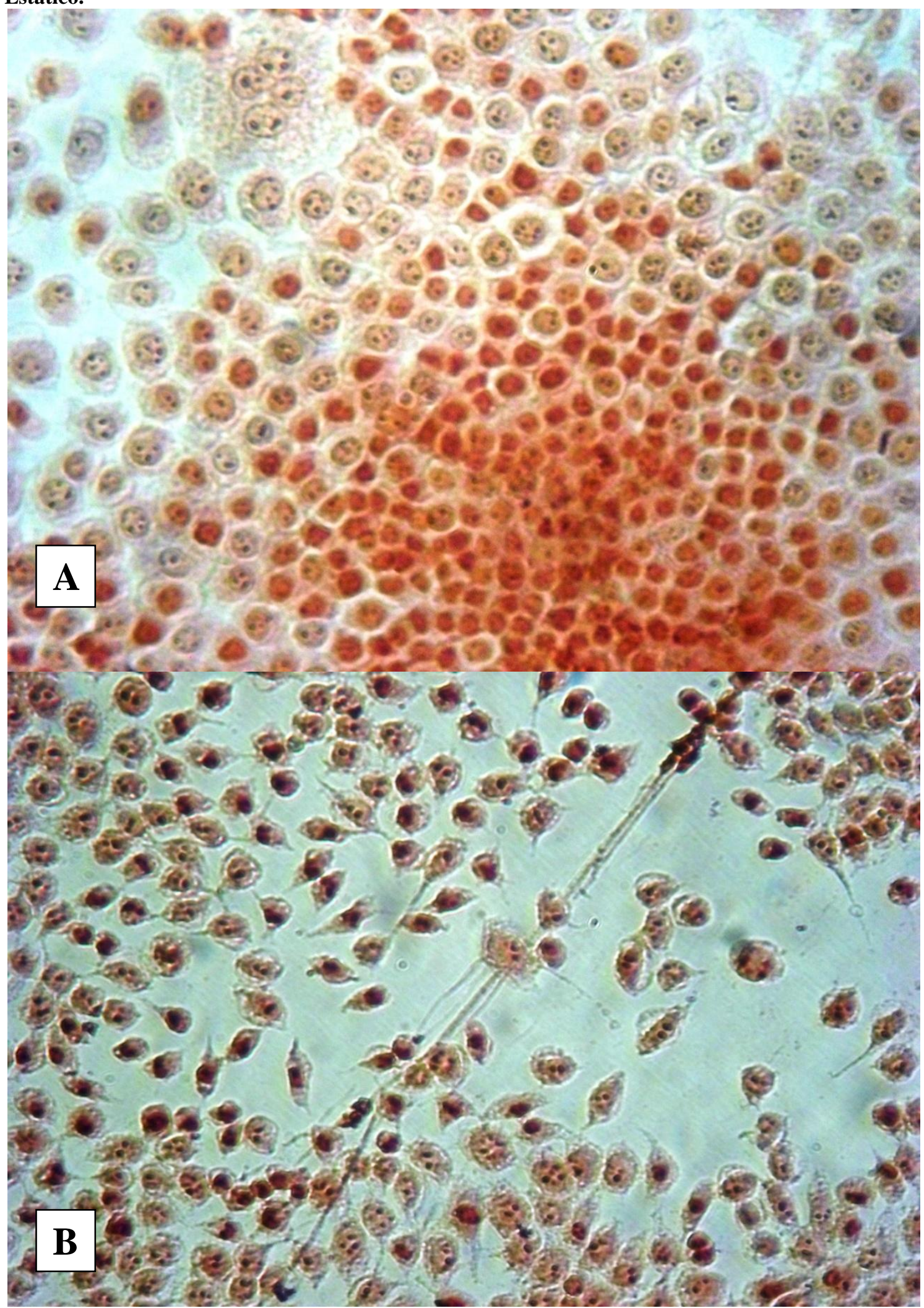

Cultura de células de fibroblastos FN1 aderidas em placas de petri e coradas com vermelho neutro. $A$ imagem " $A$ " apresenta as células de controle em condições de cultivo normal, seu formato arredondado é característico de culturas com espaço restrito para o crescimento. A imagem "B" é referente às células expostas ao CEE por 4 horas; o formato fusiforme é característico desse tipo de célula. Aumento de 160X.

Fonte: Próprio autor. 
Figura 4.7 - Imagem das células FN1 expostas ao Campo Elétrico Estático e ao quimioterápico Etoposídeo.

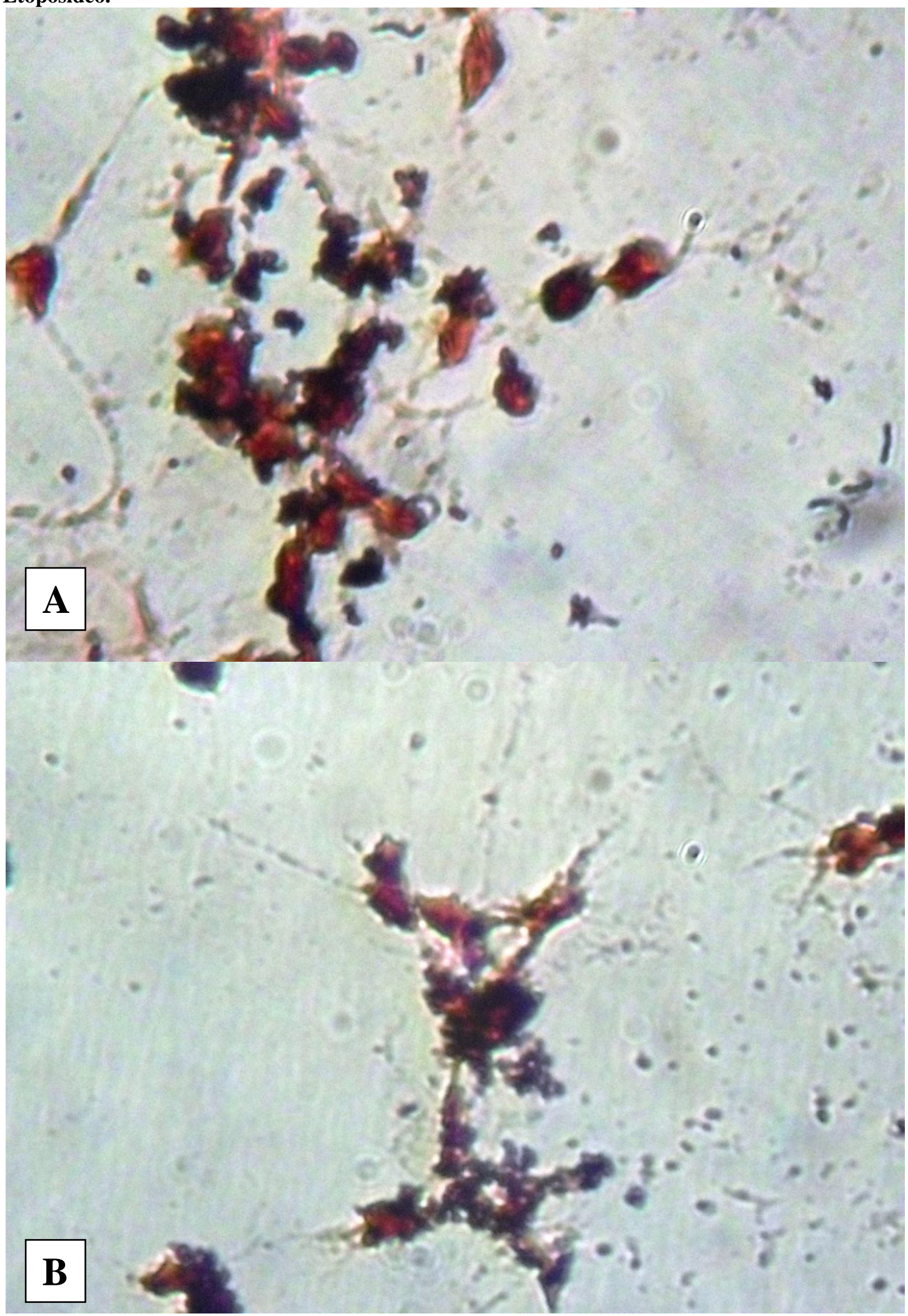

Células FN1 submetidas ao quimioterápico Etoposídeo com concentração de 0,35 mmol. Na imagem " $A$ " se encontram as células que sofreram o efeito isolado do quimioterápico, em "B" as células foram submetidas aos efeitos combinados do Etoposídeo com o CEE. Todas as células no campo de visão apresentam indícios de apoptose. Aumento de 160X com zoom digital de 3x. Fonte: Próprio autor. 


\subsection{Análise Quantitativa dos efeitos do Campo Elétrico Estático}

Para visualizar os efeitos isolados do CEE, e sua ação quando combinado com quimioterápicos, apresentamos incialmente os efeitos isolados do CEE nas culturas celulares. Os valores de todos os gráficos apresentandos se encontram nas tabelas do Apêndice.

\subsubsection{Viabilidade Celular via MTT}

O efeito isolado do Campo Elétrico Estático está representado na figura 4.8. Os histogramas referem-se a valores médios (viabilidade das linhagens estudadas), calculados a partir de seis medidas distintas, obtidos pelo teste do MTT. Na figura 4.1 as colunas à esquerda representam a linhagem B16F10, com viabilidade de 77,75\% (variância de 5,43\%) quando exposta ao CEE por 24 horas. A direita encontra-se a linhagem de fibroblasto FN1 e o valor de viabilidade pela exposição ao CEE por 24 horas é de 76,35\% (variância de 5,55\%).

Figura 4.8 - Gráfico da ação isolada do Campo Elétrico Estático na viabilidade celular.

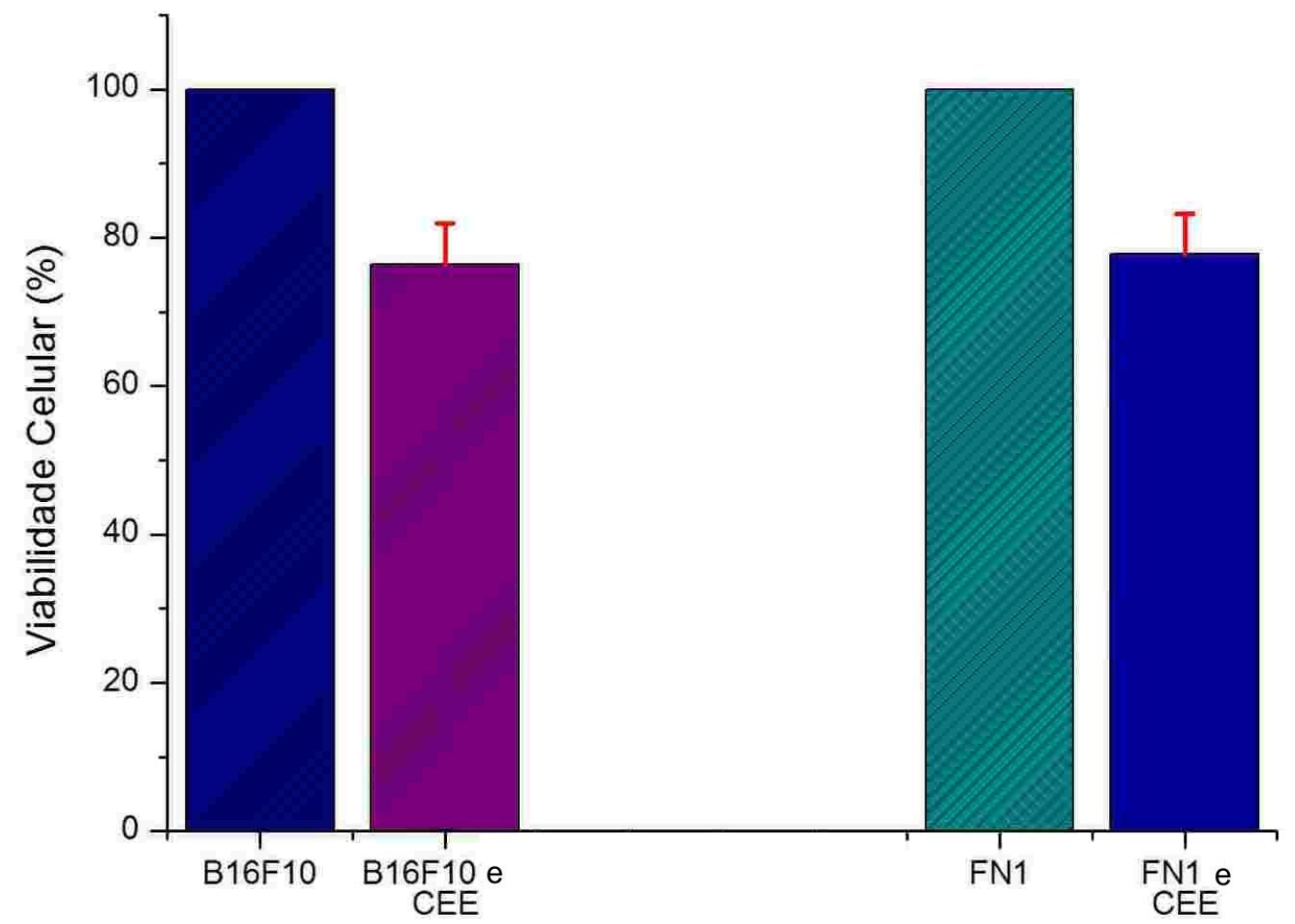

Os valores do controle estipularam o valor percentual de $100 \%$ da viabilidade celular. Ao lado direito da barra de controle se encontra a viabilidade das células submetidas ao efeito do CEE por 24 horas.

Fonte: Próprio autor. 


\subsubsection{Apoptose Quantificada Via Caspase 3}

As figuras 4.9 e 4.10 apresentam exemplos de imagens registradas via citômetro de fluxo, obtidas pelo programa WinMDI 2.8 e analisadas por density plot. Os valores são exemplos típicos da cultura celular após 6 horas de exposição. As imagens representam amostras marcadas com caspase 3 fosforilada, e os tons de verde representam a maior concentração de amostras marcadas. Os valores percentuais presentes no quadrante direito superior determinaram os índices de apoptose da cultura obtidos para as células B16F10 (figura 4.9) e FN1 (figura 4.10). É possível notar um pequeno aumento de apoptose nas células de fibroblasto FN1 em relação às células B16F10, condição esperada pela inibição da apoptose em linhagens tumorais, permitindo considerar que os valores de apoptose da cultura B16F10 são meras flutuações do resultado obtido para o controle, não indicando necessariamente um evento apoptótico real.

Figura 4.9 - Marcação com Caspase 3 das células B16F10 do grupo controle e do grupo exposto ao Campo Elétrico Estático.

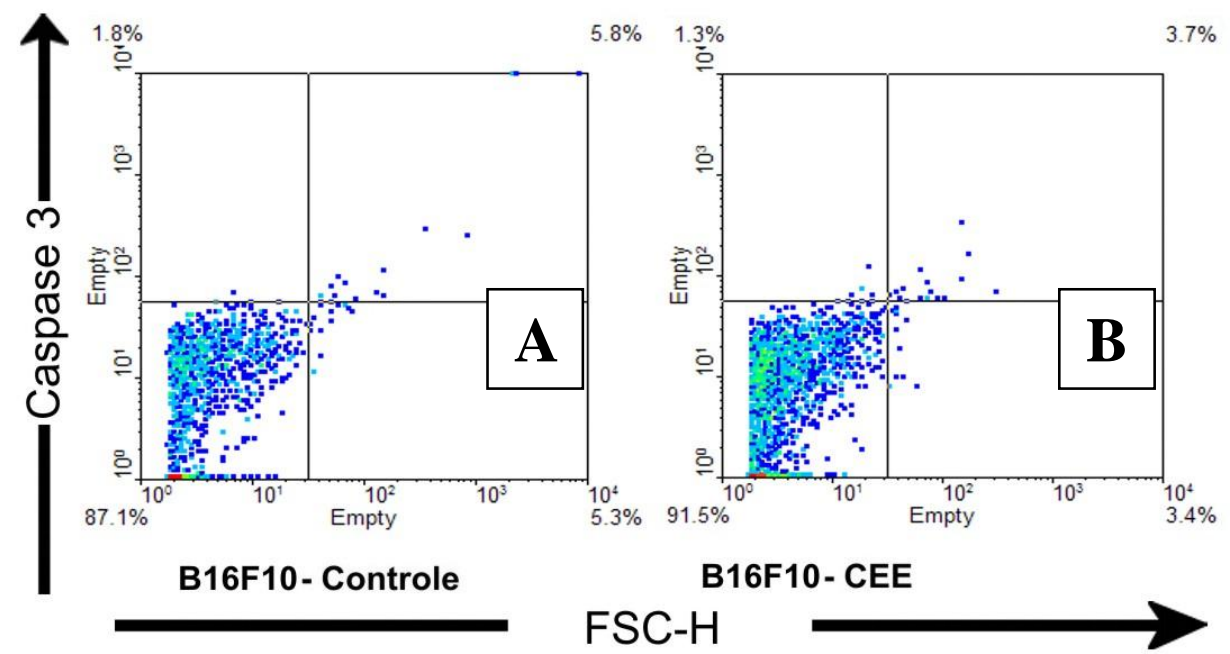

Imagens obtidas pelo programa WinMDI 2.8 referentes ao período de 6 horas na análise, pelo citômetro de fluxo, de células B16F10 marcadas com Caspase 3. Valores de apoptose na cultura em condições normais (A) e expostas ao CEE por 6 horas (B).

Fonte: Próprio autor. 
Figura 4.10 - Marcação com Caspase 3 das células FN1 do grupo controle e do grupo exposto ao Campo Elétrico Estático.

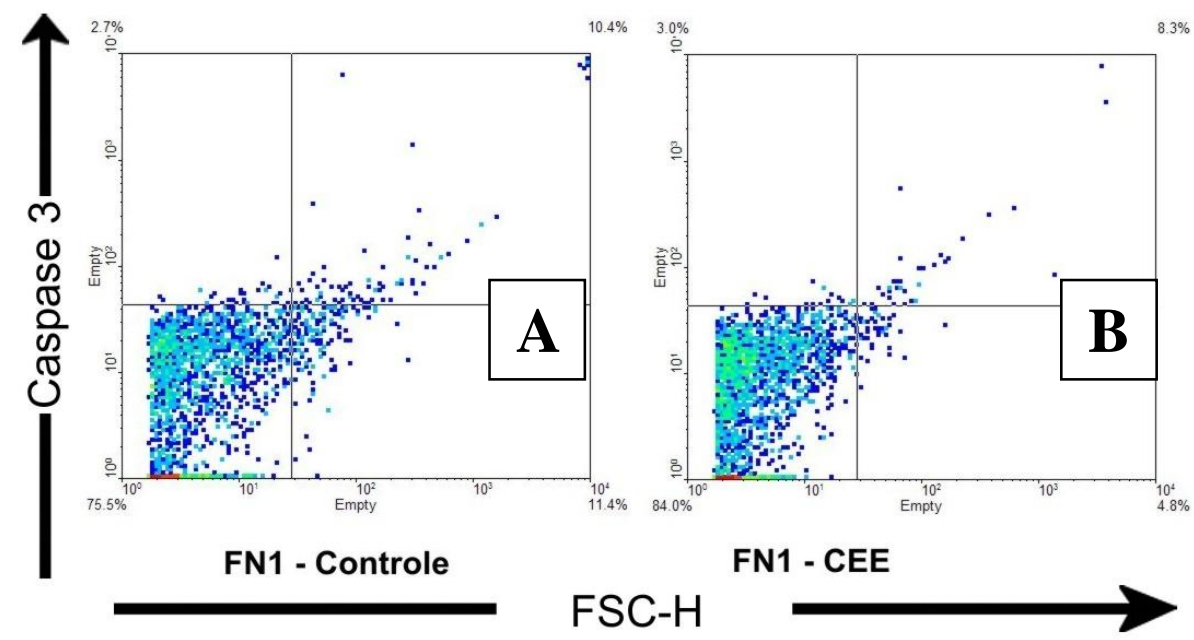

Imagens obtidas pelo programa WinMDI 2.8, com exemplos em density plot das culturas após 6h submetidas ao CEE (B) e seu grupo controle (A). Fonte: Próprio autor.

Figura 4.11 - Gráficos de apoptose via Caspase 3 do grupo controle e do grupo exposto ao Campo Elétrico Estático.
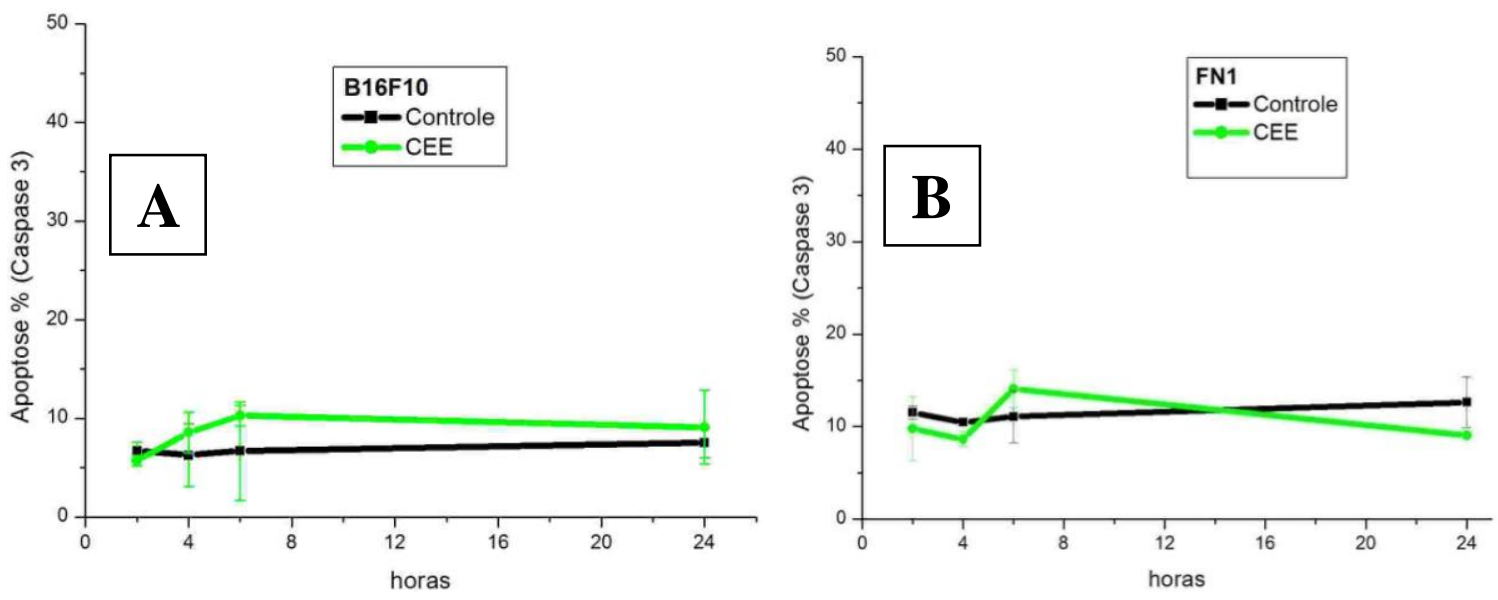

Valores referentes ao percentual de apoptose em células marcadas pela caspase 3 fosforilada. É possível identificar um valor mais alto de apoptose nas células da cultura de FN1 (B) em comparação com a linhagem tumoral $(\mathrm{A})$.

Fonte: Próprio autor.

Na figura 4.11 é possivel observar as variações de apoptose ao longo do tempo analisado para as linhages B16F10 (A) e FN1 (B), exemplificadas nas figuras 4.9 e 4.10. Não foi possível detectar qualquer variância estatisticamente significativa entre as amostras obtidas nas condições de controle e as submetidas ao CEE, durante o período de análise. 


\subsubsection{Potencial de Membrana Mitocondrial}

Figura 4.12 - Imagens dos histogramas das células marcadas com rodamina 123.
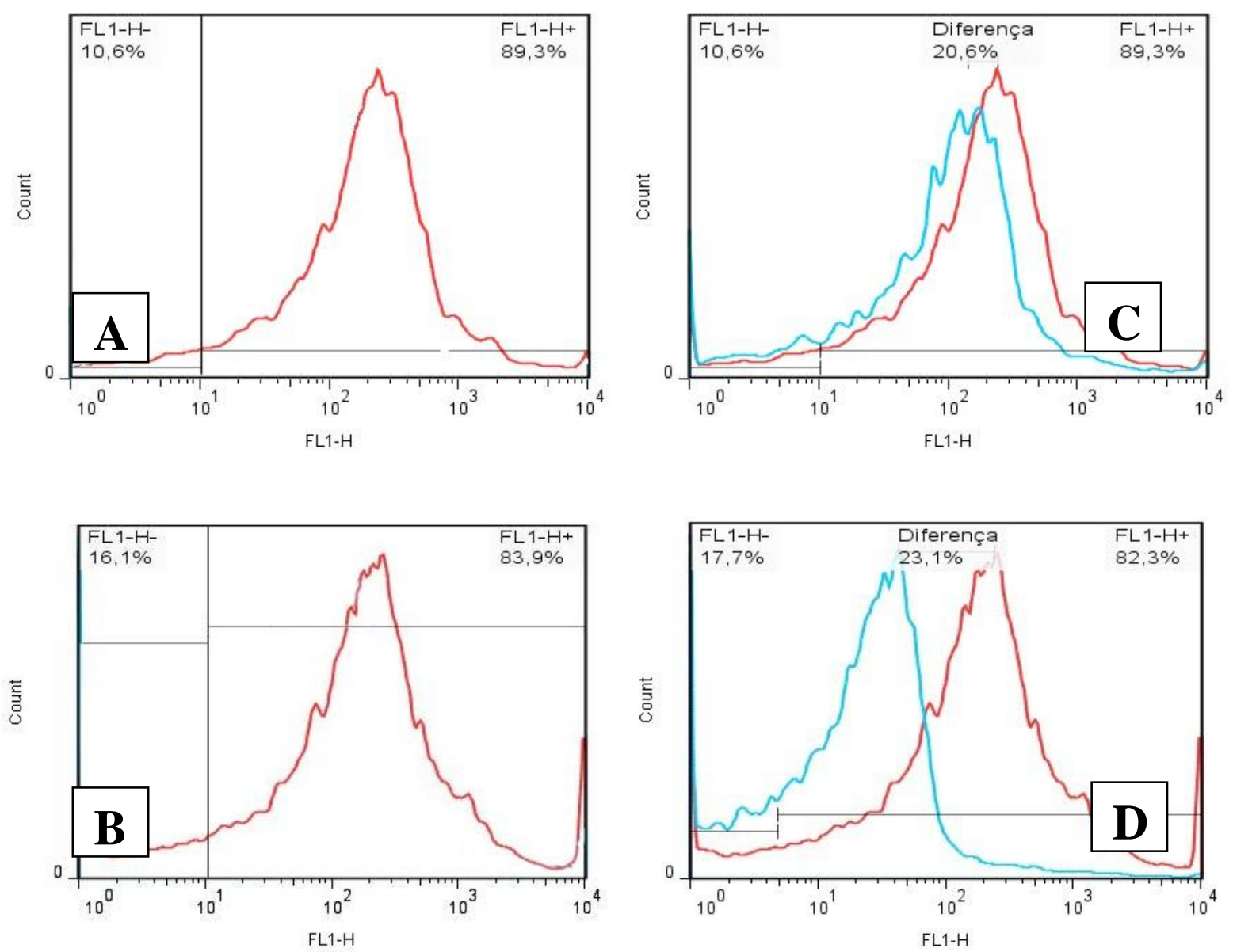

Imagens com os histogramas da atividade mitocondrial das células B16F10 e FN1 no período de 6h. Na figura A e B são apresentadas as curvas de controle da atividade mitocondrial para as células B16F10 (A) e FN1 (B). Os histogramas apresentam uma divisão referente ao número de mitocôndrias ativas (à direita) e inativas (à esquerda), quantificadas em valores percentuais e apresentadas na figura 4.13. Nas imagens " $C$ " $\mathrm{e}$ " $D$ " estão presentes as curvas comparativas do controle (em vermelho) e da atividade isolada do Campo Elétrico (em azul) nas células B16F10 (C) e FN1 (D). Os valores percentuais obtidos pela média das amostras estão na figura 4.14. Fonte: Próprio autor.

A perda do potencial de membrana mitocondrial foi medida através da diferença entre os picos das curvas (figura 4.12 A e B) e comparadas à curva obtida pelo controle das respectivas culturas (figura $4.12 \mathrm{C}$ e D). Os valores apresentados na figura 4.14 indicam uma perda aproximada de $15 \%$ do potencial para ambas as linhagens estudadas. 
Figura 4.13 - Gráficos das mitocôndrias ativas.
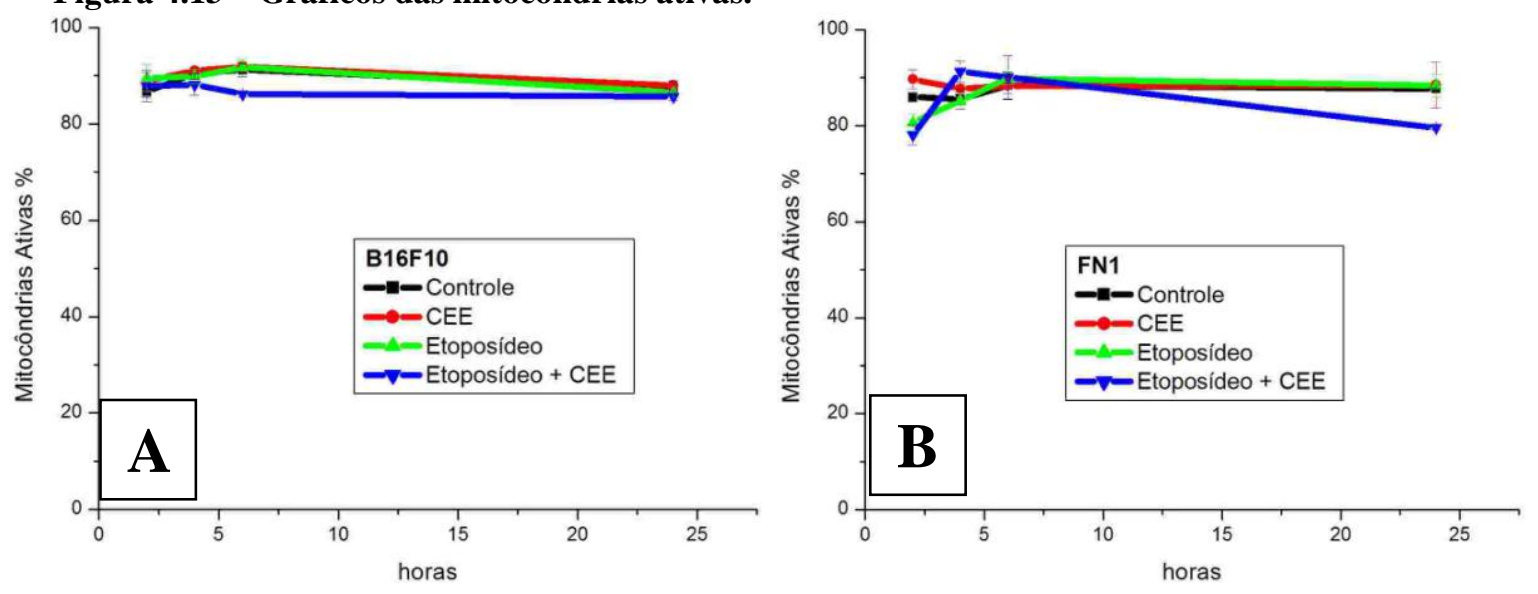

Valores percentuais das mitocôndrias ativas em função do tempo, obtidas via rodamina 123. Há um maior número de mitocôndrias ativas, próximo de 5\%, na linhagem tumoral (A) em comparação à linhagem saudável (B). Nenhum grupo experimental apresentou alterações nas mitocôndrias ativas que fosse estatisticamente significativo.

Fonte: Próprio autor.

Figura 4.14 - Gráficos da atividade mitocondrial no grupo controle e exposto ao Campo Elétrico Estático.
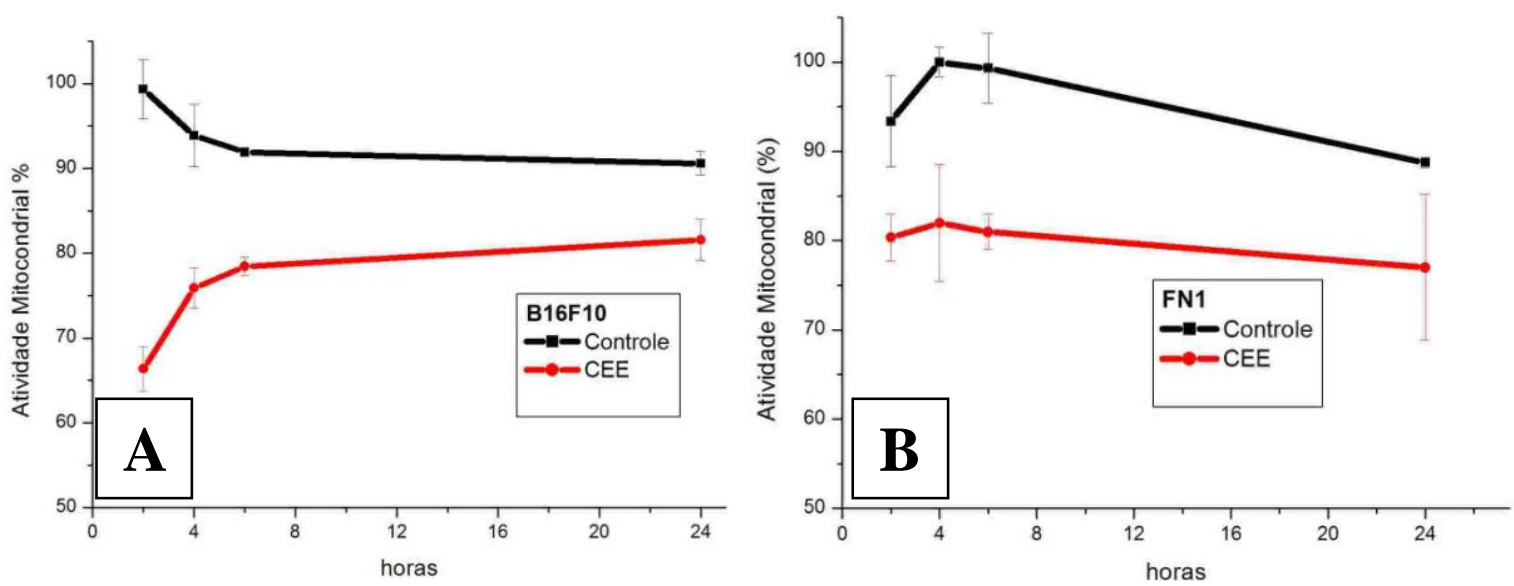

Valores da atividade mitocondrial do grupo controle comparada às células submetidas ao CEE, em função do tempo. Os resultados com o CEE tiveram uma significativa perda de potencial mitocondrial em relação ao controle.

Fonte: Próprio autor.

\subsubsection{Morte Celular Quantificada Via Anexina V/PI}

Os marcadores dos valores de anexina $\mathrm{V}$ foram analisados de forma combinada com o Iodeto de Propídio (PI) para identificar apoptose inicial, tardia ou necrose. As figuras 4.15 (linhagem B16F10) e 4.16 (FN1) mostram as imagens de density plot (pelo progrma WinMDI 2.8) das células em condições de controle (A) e expostas ao CEE (B) após seis horas do inico do experimento. Todos os quadrantes foram delimitados a partir da área do quadrante inferior esquerdo, determinado pelo area de células marcadas viáveis dos respectivos controles. para cada linhagem celular. 
Figura 4.15 - Imagens representativas de células B16F10 marcadas com anexina V/PI do grupo controle e do grupo exposto ao Campo Elétrico Estático.

\section{B16F10}

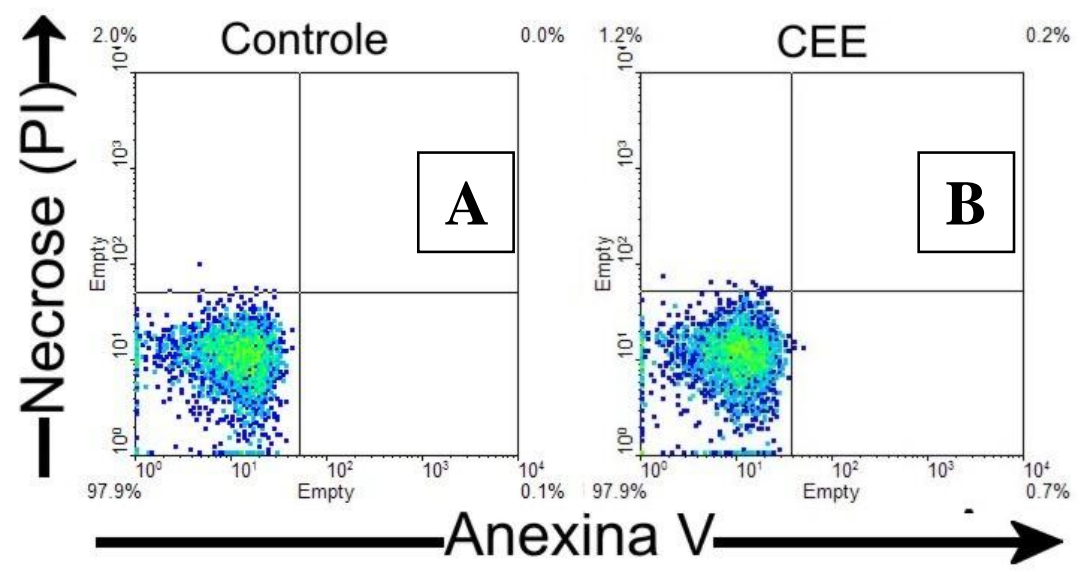

Imagem mostrando a marcação de anexina V e PI em células de cultura B16F10 (A) e células com aplicação do CCE por 6 horas (B). Ambas as imagens apresentam valores idênticos de células vivas, com forte concentração celular sem indícios significativos de apoptose ou necrose.

Fonte: Próprio autor.

Figura 4.16 - Imagens representativas de células FN1 marcadas com anexina V/PI do grupo controle e do grupo exposto ao Campo Elétrico Estático.

\section{FN1}

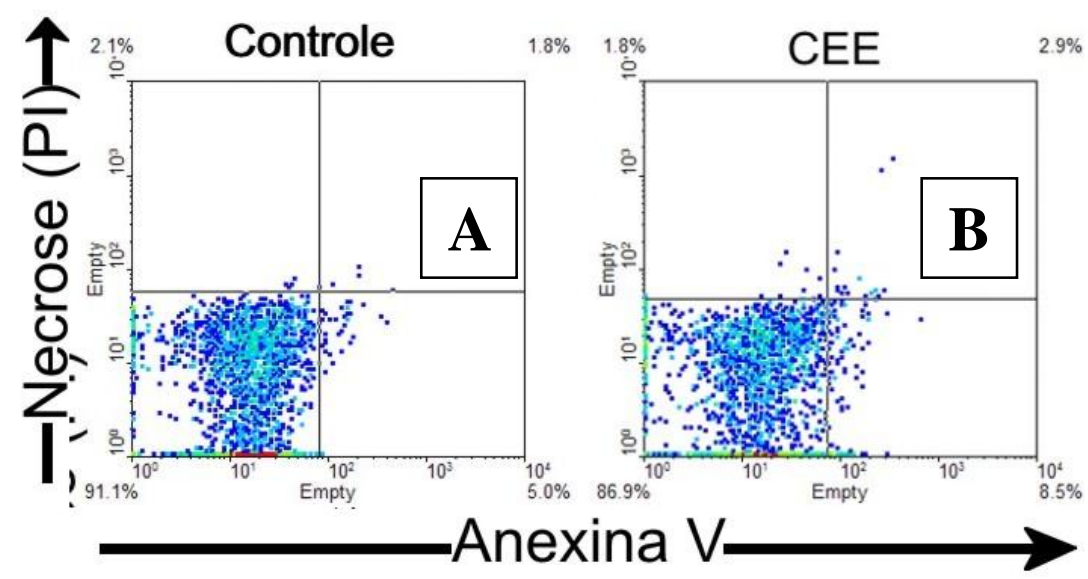

Imagem da cultura FN1 marcada com anexina V e PI em para as condições de controle (A) e com aplicação do CCE por 6 horas (B). Embora a população se comporte de forma mais difusas que a linhagem B16F10 (fig. 4.11), foi possível delimitar a área de células vivas com resultados significativos para os demais tratamentos (fig. 4.17). Fonte: Próprio autor. 
Nas figuras 4.17 e 4.18 é possivel identificar as variações de células vivas de cada linhagem (B16F10 e FN1, respectivamente) com os respectivos indices de apoptose (tardia e inicial) e necrose nas células do grupo controle (A) e expostas ao campo elétrico (B). Com resultados similares aos valores obtidos pelo marcador de capase 3 fosforilada, não houve indicação de apoptose ou necrose induzida pela exposição ao CEE.

Figura 4.17 - Gráficos das células B16F10 marcadas com anexina V/PI do grupo controle e do grupo exposto ao Campo Elétrico Estático.
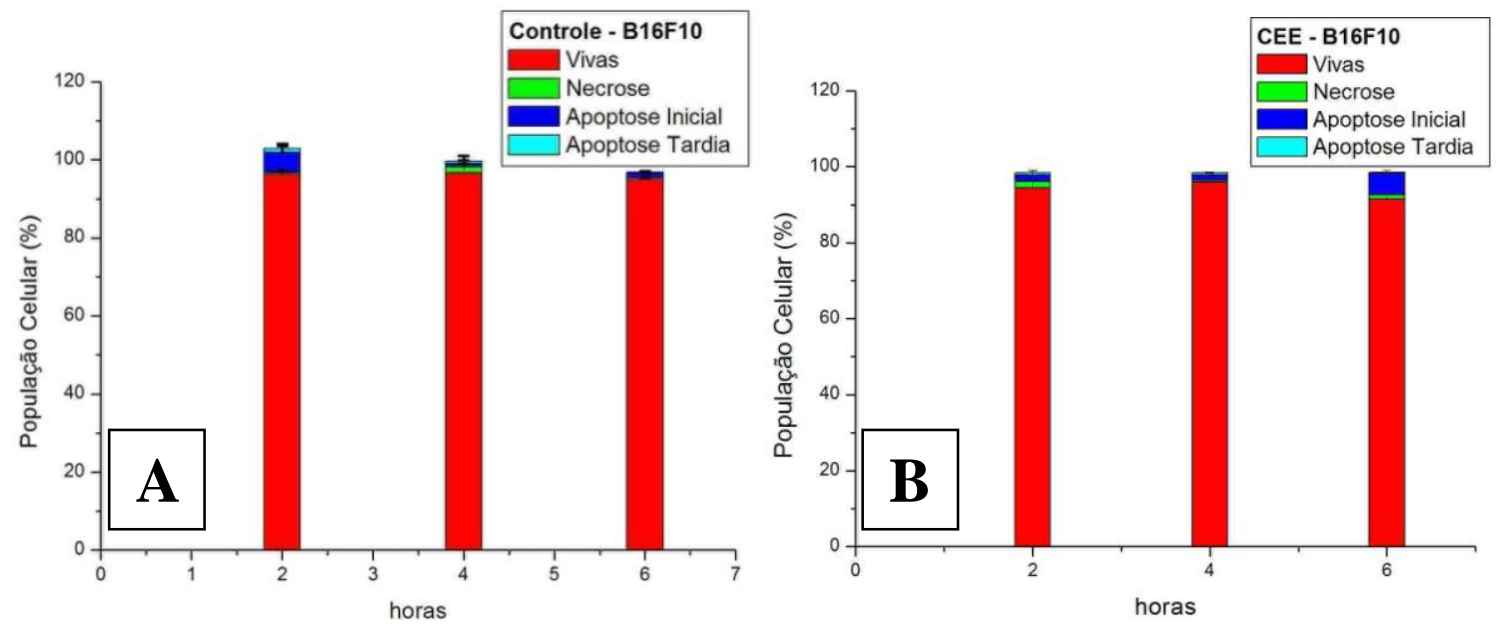

Valores percentuais na população de células tumorais B16F10 nas condições: vivas, em apoptose inicial, apoptose tardia e necrose, nos valores do grupo controle (A) e expostas ao CEE (B), ambas em função do tempo. Os valores somados das quatro condições celulares mensuradas são próximos de $100 \%$ ( \pm 5 ).

Fonte: Próprio autor. 
Figura 4.18 - Gráficos das células FN1 marcadas com anexina V/PI do grupo controle e do grupo exposto ao Campo Elétrico Estático.
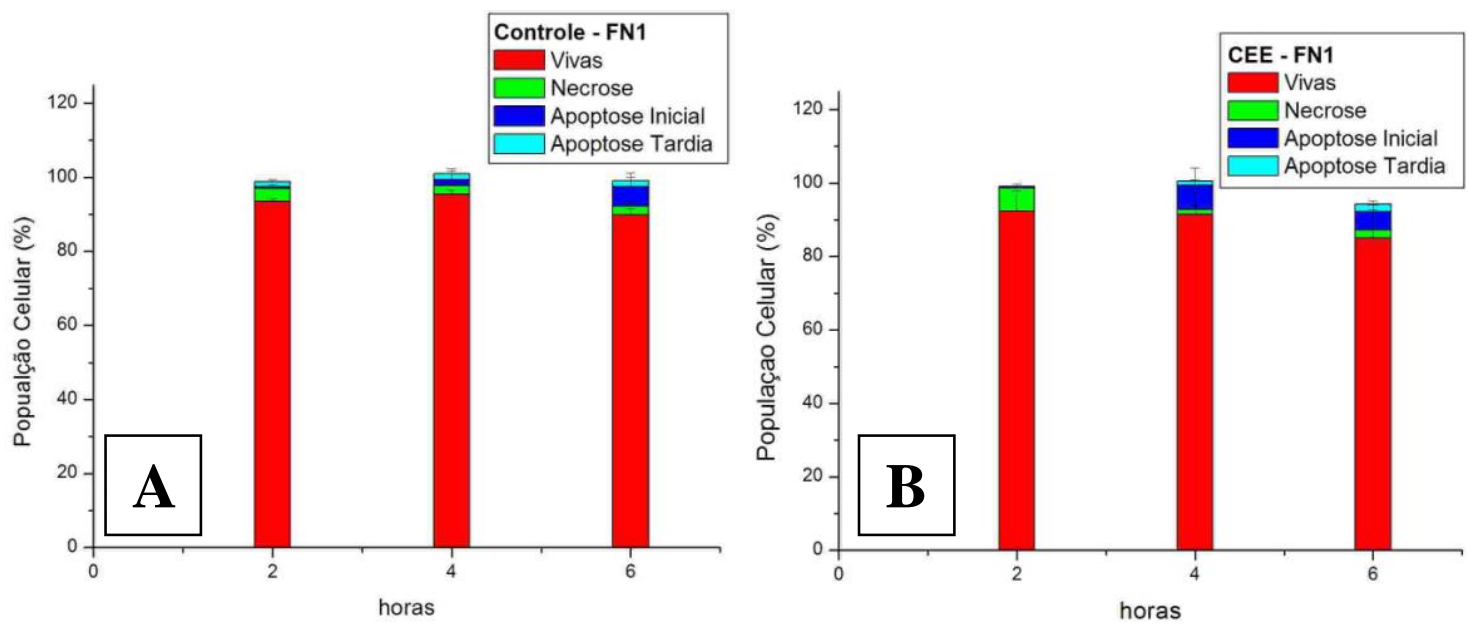

Similar ao resultado com B16F10 (figura 4.17), a ação isolada do CEE não induziu ou favoreceu morte celular na população de fibroblastos FN1 em exposições de até 6 horas. Comparada à linhagem tumoral B16F10 a cultura controle apresentou leves sinais de morte celular, com índices um pouco mais altos de apoptose inicial, resultado compatível com o observado pelo teste de caspase 3.

Fonte: Próprio autor.

\subsection{Análise quantitativa do CEE combinado com Quimioterápico}

Nesse tópico apresentamos os efeitos dos quimioterápicos nas culturas testadas e os efeitos combinados com CEE. Em algumas figuras optou-se por reapresentar os resultados já exibidos no tópico anterior, com o intuito de faciltiar a visualização e comparação dos efeitos do tratamento combinado do CEE com o Etoposídeo quando comparados às condições sem tratamento (Controle) e efeitos isolados do CEE. Assim como no tópico anterior, todos os valores dos gráficos estão presentes no Apêndice.

\subsubsection{Viabilidade Celular com Etoposídeo e CEE via MTT}

O teste de citotoxicidade colorimétrico de MTT permitiu estabelecer os efeitos do CEE em função da concentração do quimioterápico, possibilitando estudar a ação do CEE na viabilidade celular afetada pelo Etoposídeo. O efeito é perceptivel diretamente nas placas, pela perda de intensidade na coloração do MTT (figura 4.19 de A para B), sendo bem expressivo no decaimento das curvas nos gráficos (figura 4.20). Os resultados da exposição ao CEE indicam uma redução intensa na viabilidade, com valores de redução muito próximos em ambas as linhagens. 
Figura 4.19 - Fotografia das placas de cultura coradas com MTT.

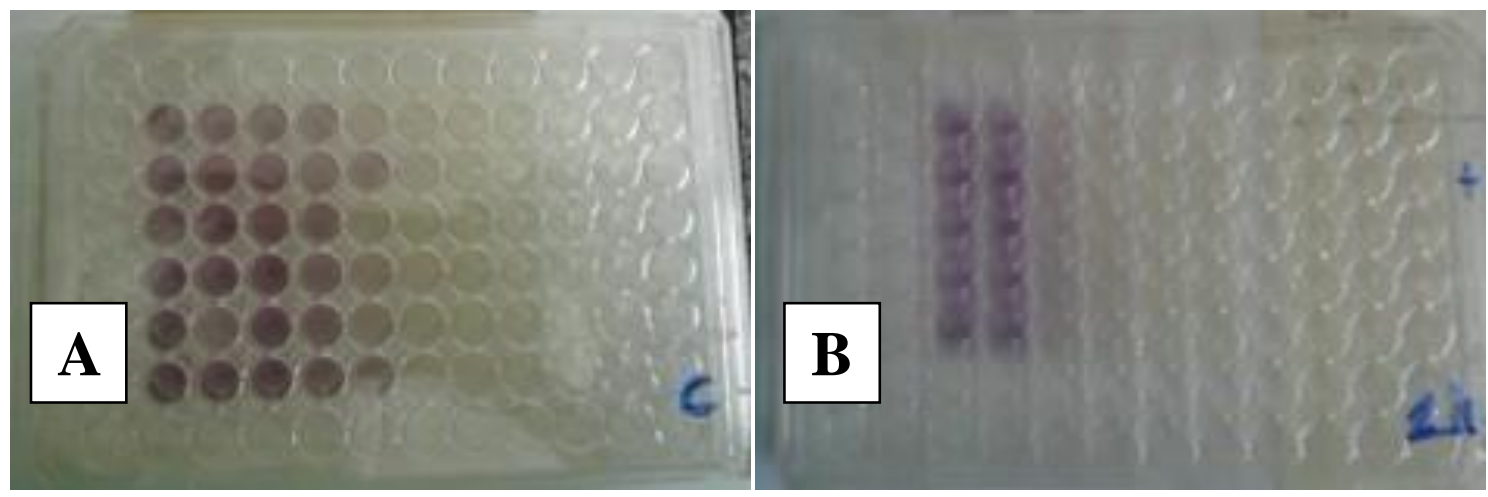

Fotografia de duas placas dos grupos experimentais do controle (A) e sob efeito do CEE (B), ambas com aplicação de Etoposídeo por 24 horas. Os orifícios das duas primeiras colunas à esquerda não receberam quimioterápico (dose 0), com aumento da concentração gradual de quimioterápico nas colunas para direita.

Fonte: Próprio autor.

Figura 4.20 - Gráficos com as curvas de citotoxicidade do Etoposídeo e Campo Elétrico Estático pelo MTT.
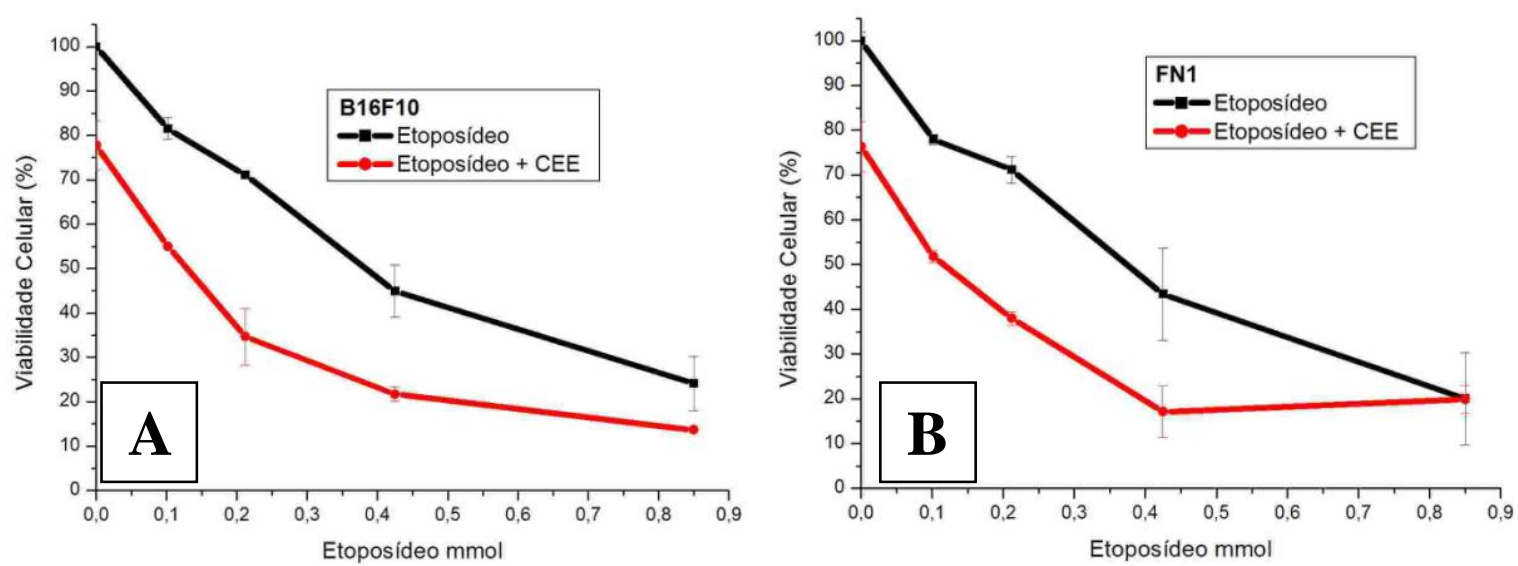

Curvas com os valores de citotoxicidade pelo MTT das linhagens B16F10 (A) e FN1 (B), no grupo controle (linha preta) e quando submetidas ao CEE (linha vermelha), ambas em função da concentração de Etoposídeo. Cada curva do gráfico é resultado dos valores médios entre quatro experimentos distintos, onde as barras de erro representam a variância.

Fonte: Próprio autor.

Para facilitar a determinação do $\mathrm{IC}_{50}$ (Índice Celular de 50\%), foi realizado o ajuste dos valores para uma reta de tendência (figura 4.21), obtendo os valores de 0,49 mmol para as células melanocíticas B16F10 (figura 4.21 A) e 0,46 mmol para os fibroblastos da linhagem celular FN1 (figura 4.21 B). 

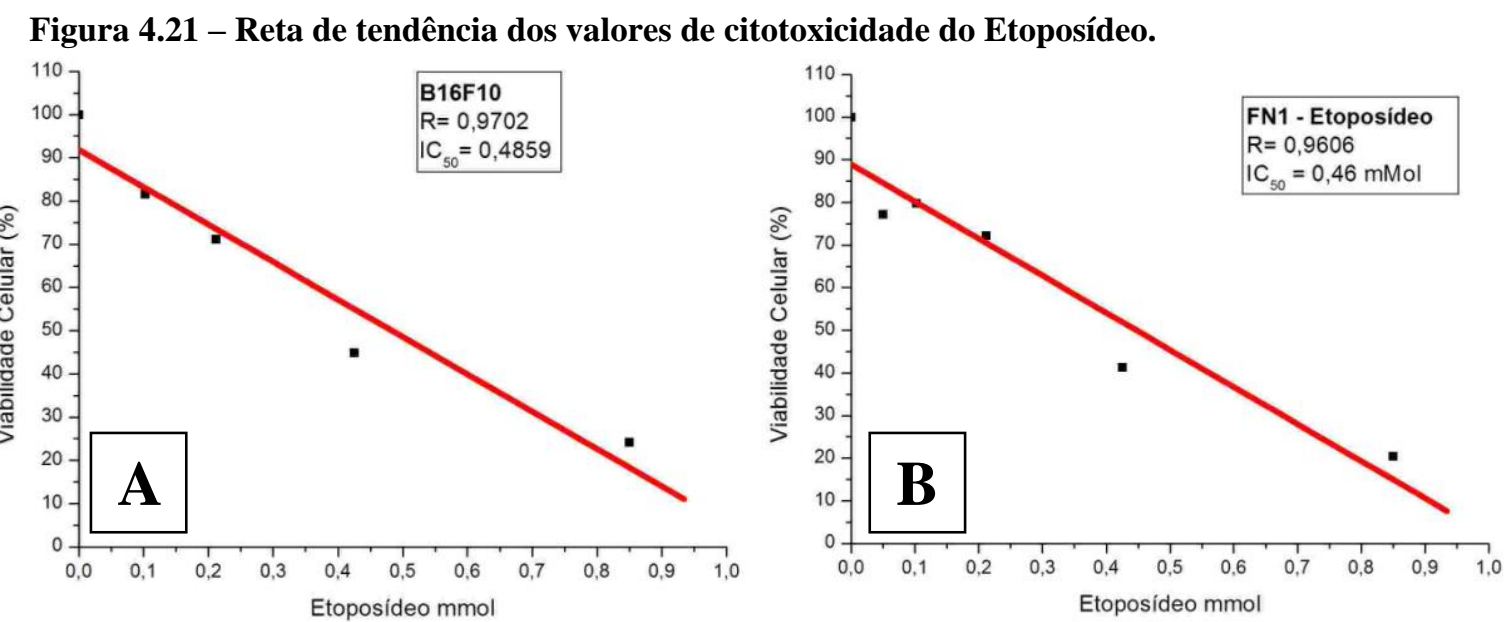

Ajuste dos resultados em uma reta de tendência, exibindo a redução da viabilidade celular em função da concentração de Etoposídeo para as linhagens B16F10 (A) e FN1 (B). Baseado no ajuste foi possível estimar o valor da $\mathrm{IC}_{50}$ de cada cultura, apresentado no quadro da legenda.Fonte: Próprio autor.

Figura 4.22 - Ajuste dos resultados do efeito associado do Campo Elétrioc Estático com o Etoposídeo em uma curva de tendência.
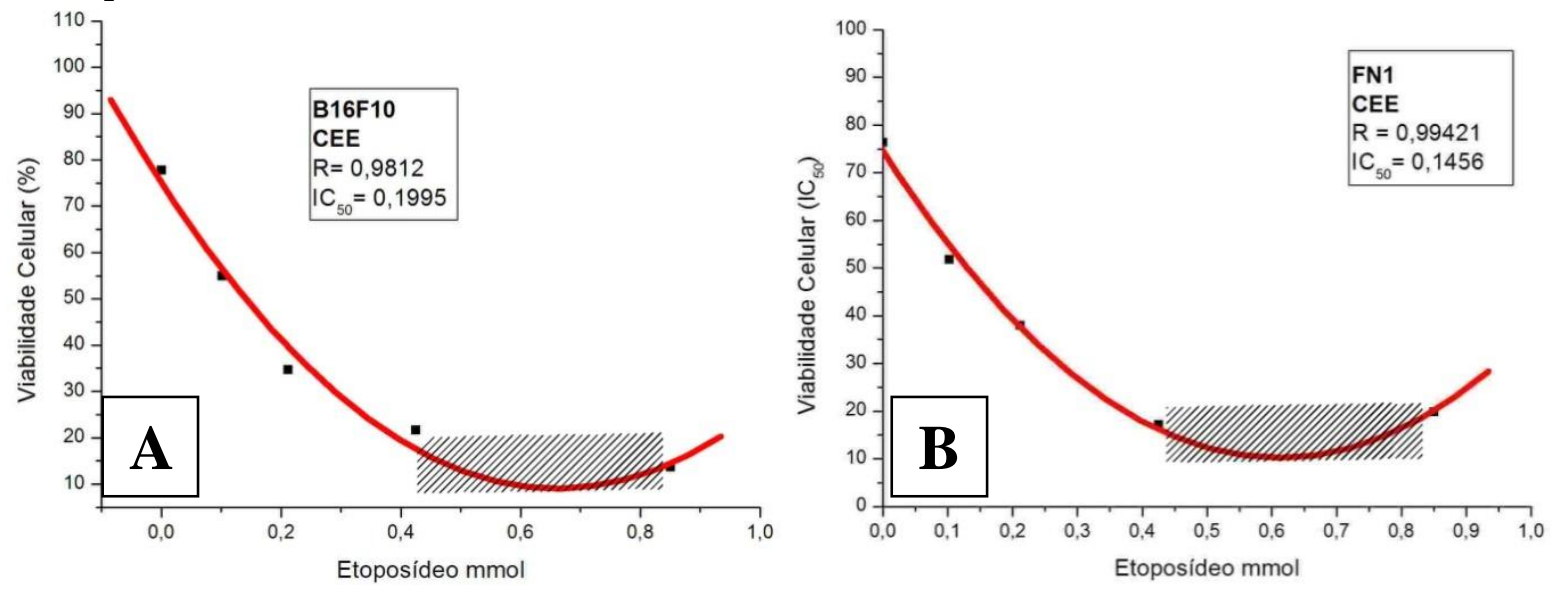

A viabilidade celular decai de forma intensa e não linear, em contraste com a reta de tendência do efeito isolado dos quimioterápicos. Os resultados novamente foram quase idênticos para as linhagens B16F10 (A) e FN1 (B). O comportamento da curva na região hachurada se aproxima de um patamar, com valores similares.

Fonte: Próprio autor.

Diferente da reta estabelecida no gráfico da figura 4.21, não foi estatisticamente possível realizar esse mesmo ajuste aos dados referentes ao efeito do quimioterápico combinado com a exposição ao CEE (figura 4.22). O melhor índice de ajuste para uma curva de tendência foi obtido com uma curva polinomial de grau 2 (parábola). A região de mínimo dessa curva corresponde às concentrações de $0,43 \mathrm{mmol}$ até $0,85 \mathrm{mmol}$, formando um patamar com valores de viabilidade muito próximos entre si. Devido a esse comportamento peculiar marcamos a região da curva com uma barra hachurada, para destacar que nessa faixa de concentrações os dados não se comportam como em uma curva de tendência “convencional” (figura 4.22). 
Figura 4.23 - Curvas de viabilidade celular das culturas B16F10 (A) e FN1(B) em função do quimioterápico Paclitaxel.
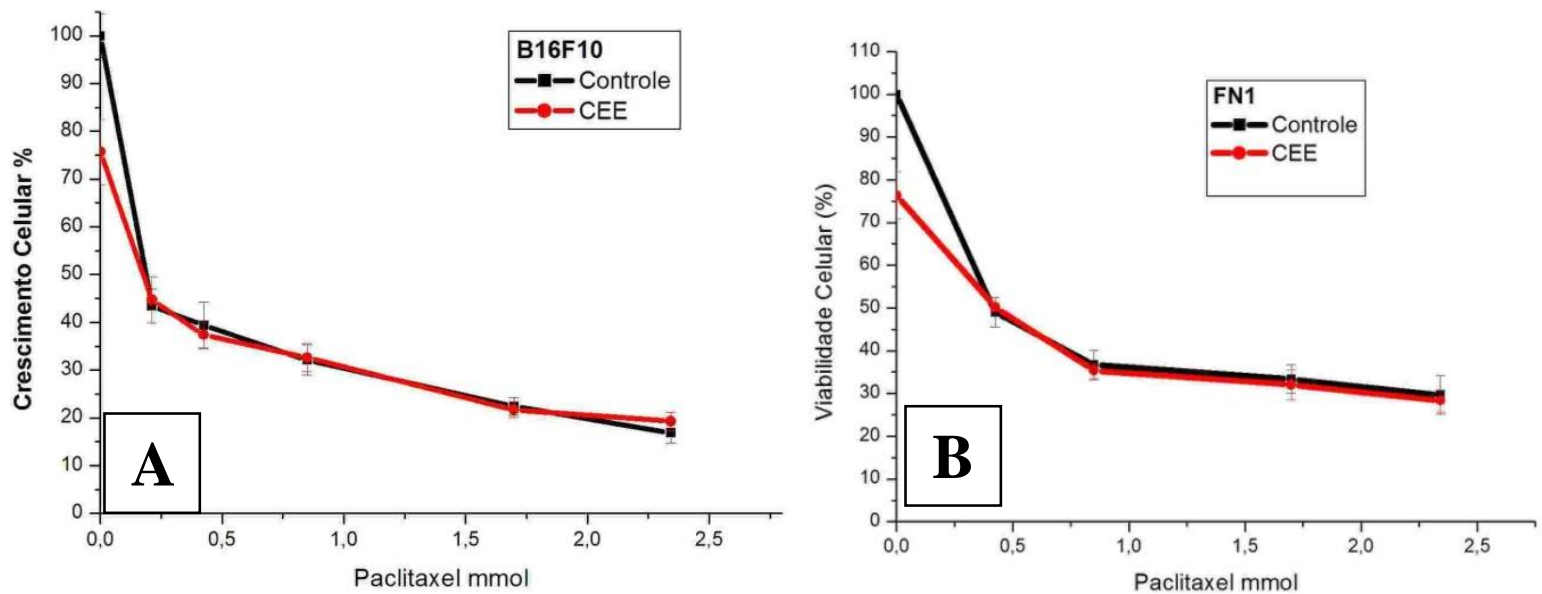

Os valores inicias (dose 0) apresentam uma redução em função dos efeitos isolados do CEE, ocorrendo uma superposição das curvas nas demais concentrações.

Fonte: Próprio autor.

Para determinar os efeitos do CEE em função de um agente químico inibidor, que não promovesse danos do tipo DSB, foram realizados os experimentos com o CEE em função da concentração do quimioterápico Paclitaxel. Os resultados médios entre três ensaios experimentais indicam que o CEE não afeta os valores de viabilidade do Paclitaxel (figura 4.23).

Figura 4.24 - Gráfico com as curvas da razão do Campo Elétrico Estático em função do Etoposídeo.
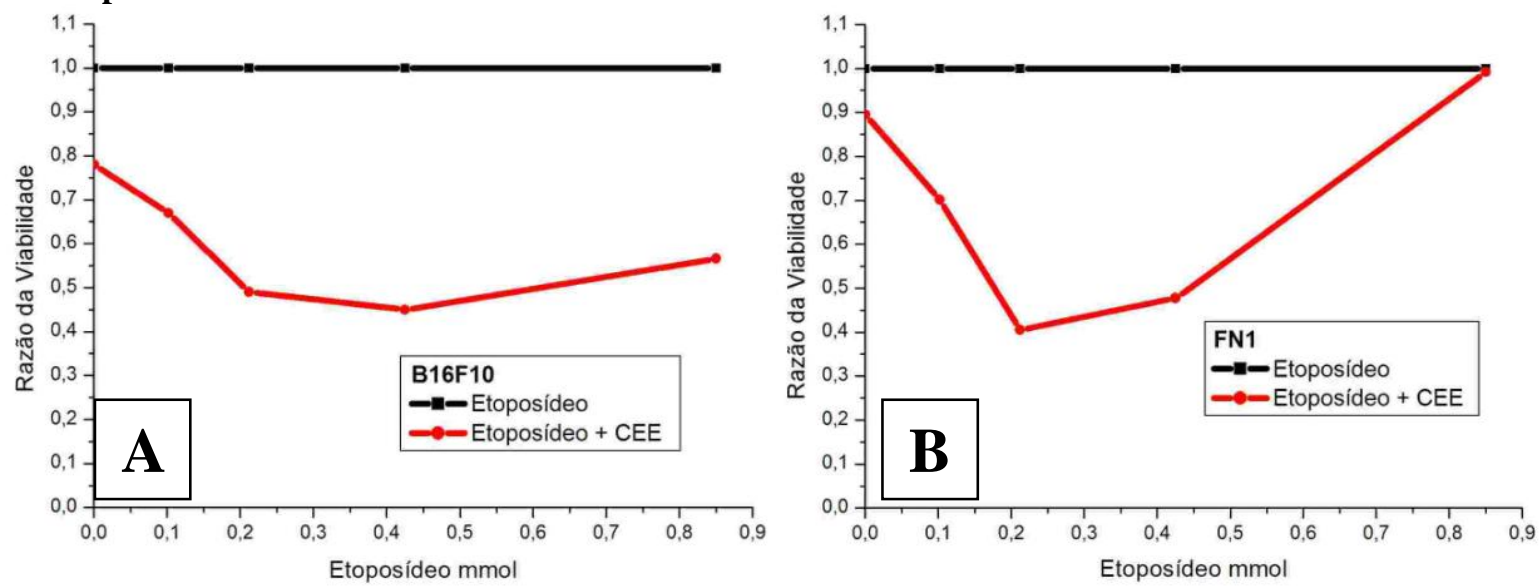

Razão do CEE em função do Etoposídeo para as linhagens B16F10 (A) e FN1 (B). Os valores da razão para concentrações de Etoposídeo entre 0,2 e 0,4 mmol indicam que pela ação do CEE a redução adicional da viabilidade é superior a $50 \%$.

Fonte: Próprio autor.

A figura 4.24 foi construído a partir de valores obtidos pela divisão da viabilidade celular devida ao Etoposídeo mais exposição ao CEE pela viabilidade celular devida ao Etoposídeo (essas duas viabilidades são mostradas na figura 4.20). 
Um gráfico de razão permite isolar um dos agentes relativamente ao outro. No caso do gráfico na figura 4.24, a razão representada em vermelho corresponde ao efeito adicional devido ao CEE relativamente ao efeito devido ao Etoposídeo isoladamente. No caso da linhagem B16F10 (figura 4.24 A) os efeitos adicionais do CEE exibem um patamar para concentrações superiores a $0,2 \mathrm{mmol}$, indicando um acréscimo de $50 \%$ na mortalidade. Com a linhagem de fibroblasto FN1 (Figura 4.24 B) a razão decresce mais pronunciadamente até a concentração de $0,2 \mathrm{mmol}$.

Figura 4.25 - Valores de viabilidade com intervalos de tempo entre o Etoposídeo e o Campo Elétrico Estático.

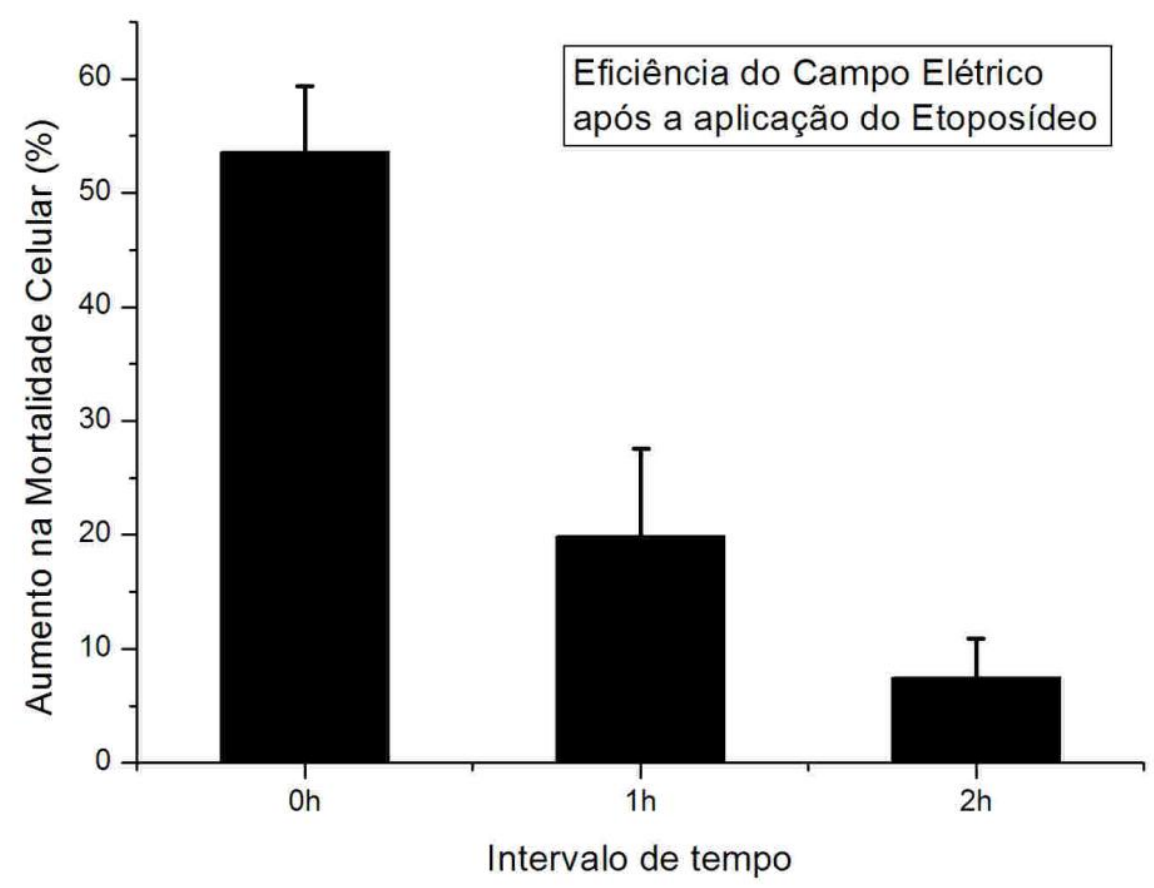

Percentual dos valores médios das razões para células FN1 (mostradas na figura $4.24 \mathrm{~B}$ ) para concentrações entre 0,2 e $0,4 \mathrm{mmol}$. Os períodos de tempo são referentes ao intervalo entre a aplicação do Etoposídeo e a aplicação do CEE.

Fonte: Próprio autor.

Na figura 4.25 foi apresentado resultados para o efeito da redução na viabilidade celular pela ação do $\mathrm{CEE}$ em função do intervalo de tempo após a aplicação do Etoposídeo. O valor das barras no gráfico representa o valor percentual da redução de viabilidade em relação ao grupo controle, com a média das concentrações de 0,2 e 0,4 mmol e com intervalos de 0,1 e 2 horas entre a aplicação do Etoposídeo e do Campo. À medida que aumenta o intervalo entre a aplicação do Etoposídeo e do CEE ocorre uma redução da eficiência do CEE em diminuir a viabilidade celular. No maior intervalo de tempo, o período de 2 horas, a viabilidade apresenta o valor de 7,5\%, inferior ao desvio 
da variância do MTT nos grupo controle do gráfico da figura 4.20 e, portanto, sem significância estatística. Os respectivos valores dos gráficos na figura 4.20 e Figura 4.26 estão respectivamente presentes nas tabelas A.7 e A.10.

\subsubsection{Apoptose com Etoposídeo e CEE Quantificada Via Caspase 3}

As figuras 4.26 e 4.27 apresentam imagens do density plot para as células marcadas por Caspase 3 fosforilada, num período de 6 horas de exposição ao Etoposídeo (A) e Etoposídeo concomitante ao CEE (B). As imagens forma obtidas via o programa WinMID 2.8 e apresentam valores representativos dos resultado médios das linhagens celulares B16F10 (figura 4.26) e FN1 (figura 4.27). As condições de análise e determinação dos valores de apotose são as mesmas descritas no item 4.2.2 do atual capítulo, sendo os respectivos valores de apoptose indicados no canto direito superior de cada figura. Todos os experimentos utulizaram a concentração de 0,17 mmol de Etoposídeo.

Figura 4.26 - Imagens representativas de células FN1 marcadas com caspase 3 dos grupos tratados com Etoposídeo.

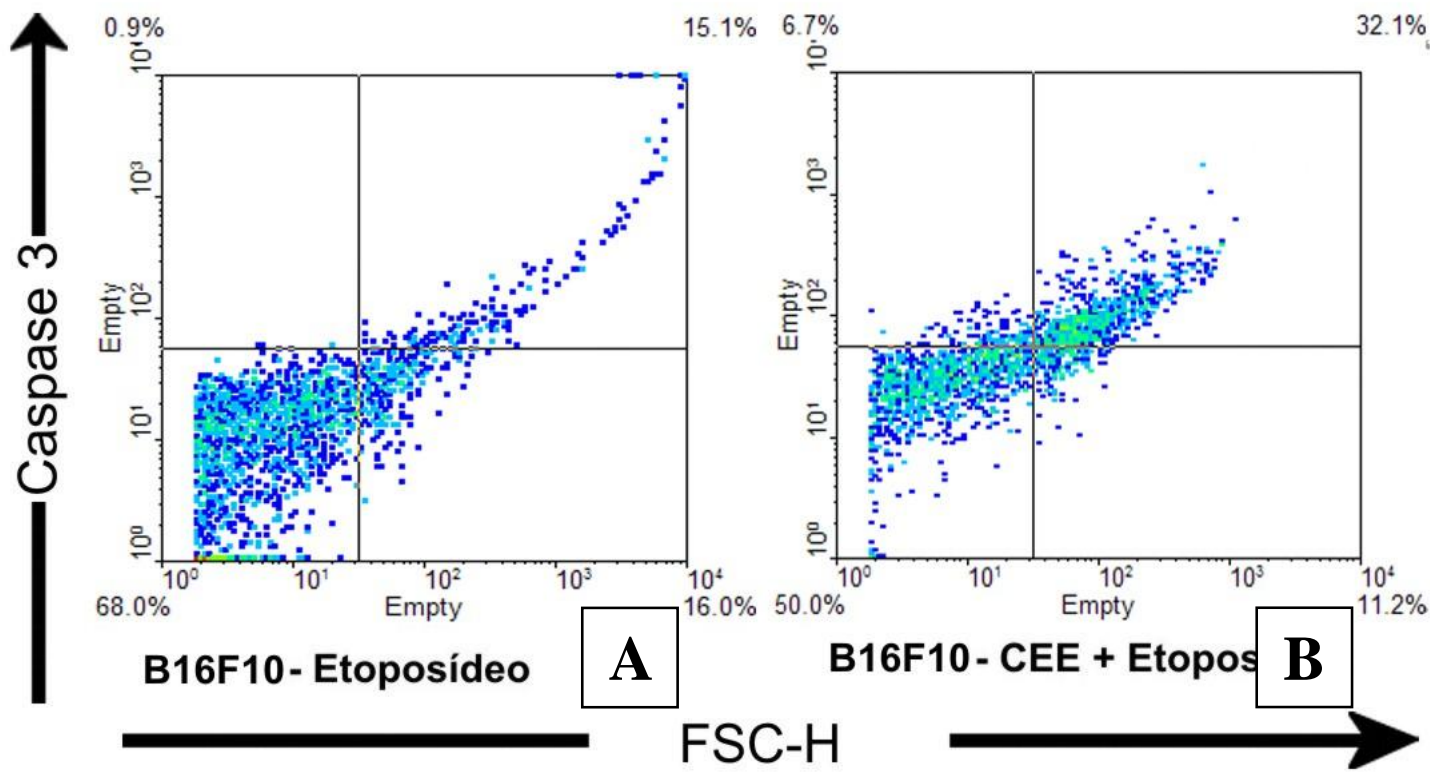

Imagens density plot das células com marcadores de Caspase 3, indicando apoptose para a linhagem celular B16F10. Sob a ação do Etoposídeo as células melanocíticas apresentam um valor de apoptose de $15 \%$ (canto superior direito), índice que é duplicado pela ação combinado com o CEE. Comparando-se os resultados de "A" (apenas com Etoposídeo) e "B" (Etoposídeo e CEE) podemos perceber aumento expressivo no deslocamento de pontos marcados ao longo do eixo Y (Caspase 3). Fonte: Próprio autor. 
Figura 4.27 - Imagens representativas de células FN1 marcadas com caspase 3 dos grupos tratados com Etoposídeo.

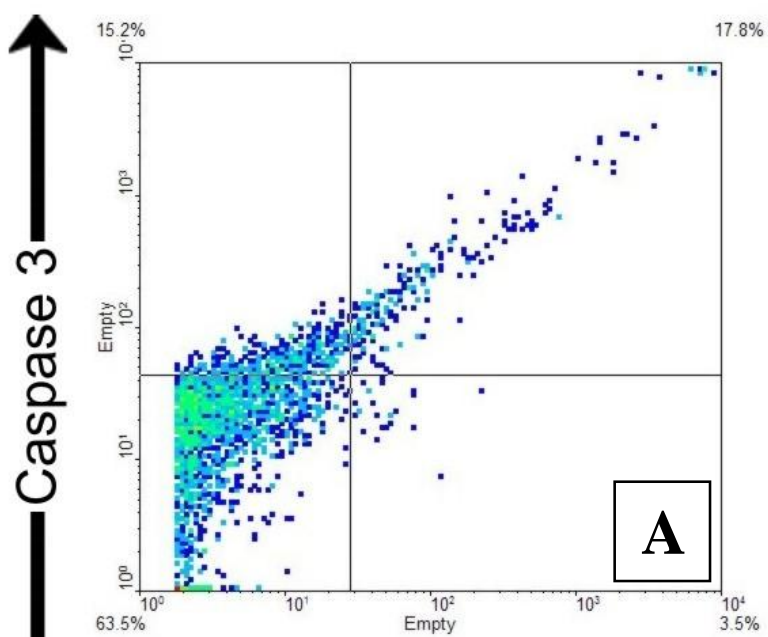

FN1 - Etoposídeo

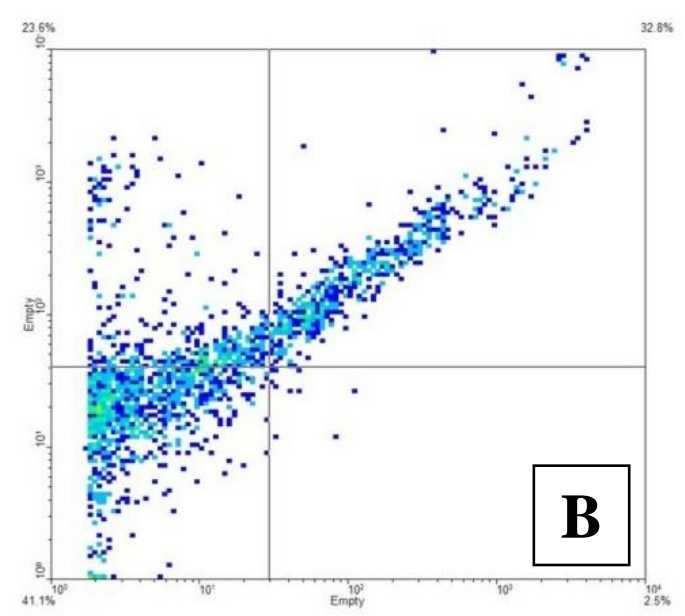

FN1 - CEE + Etoposídeo

\section{FSC-H}

Indicadores de apoptose pelo efeito do Etoposídeo para a linhagem de fibroblasto FN1 num período de 6 horas. A presença de pontos deslocados na diagonal ascendente da imagem " $A$ " para a "B" evidência o aumento de apoptose que ocorre sob ação do CEE.

Fonte: Próprio autor.

Figura 4.28 - Gráficos de apoptose via Caspase 3 dos grupos tratados com Etoposídeo.
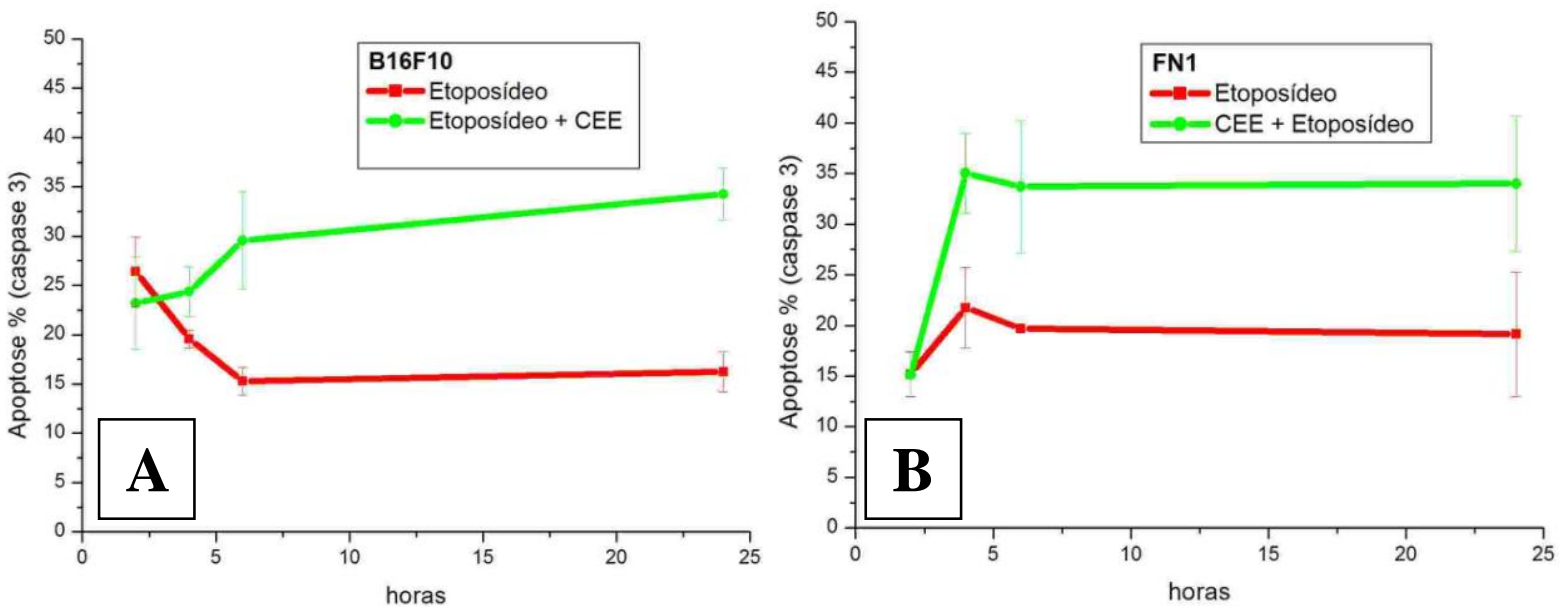

Índices de apoptose (via caspase 3), em função do tempo. Embora o período de 2 horas não tenha relevância estatística para ambas as linhagens, assim como o período de 4 horas para as células B16F10 (A), os valores se tornam significantes e expressivos nos períodos subseqüentes.

Fonte: Próprio autor.

Na figura 4.28 são apresentados os valores de apoptose (via caspase 3) pela ação isolada do Etoposídeo e combinado com exposição ao CEE nas linhagens B16F10 e FN1 (A e B, respectivamente). Na linhagem B16F10 é visível o efeito de queda da atividade da caspase 3 pela ação do Etoposídeo nas primeiras 4 horas, em contraste com 
o aumento induzido pelo CEE. O efeito do campo aumenta a apoptose significativamente, dobrando os valores e estabelecendo um patamar de $30 \%$ para B16F10 (A) e 35\% para FN1 (B).

\subsubsection{Morte Celular por Etoposídeo e CEE Quantificada via Anexina V/PI}

As figuras 4.29 (linhagem B16F10) e 4.30 (FN1) mostram as imagens de density plot (pelo programa WinMDI 2.8) das células com aplicação de Etoposídeo (C) e Etoposídeo com exposição ao CEE (D) pelo período de seis horas. As imagens foram combinadas com as figuras 4.15 e 4.16 (B16F10 e FN1, respectivamente) para facilitar a visualização das células marcadas nos eixos de anexina e PI. Os valores presentes nos cantos dos quadrantes representam o percentual de células que apresentaram: morte por necrose (quadrante superior esquerdo); apoptose tardia (quadrante superior direito) e apoptose inicial (quadrante inferior direito).

Figura 4.29 - Imagens representativas de células B16F10 marcadas com anexina V/PI.

\section{B16F10}

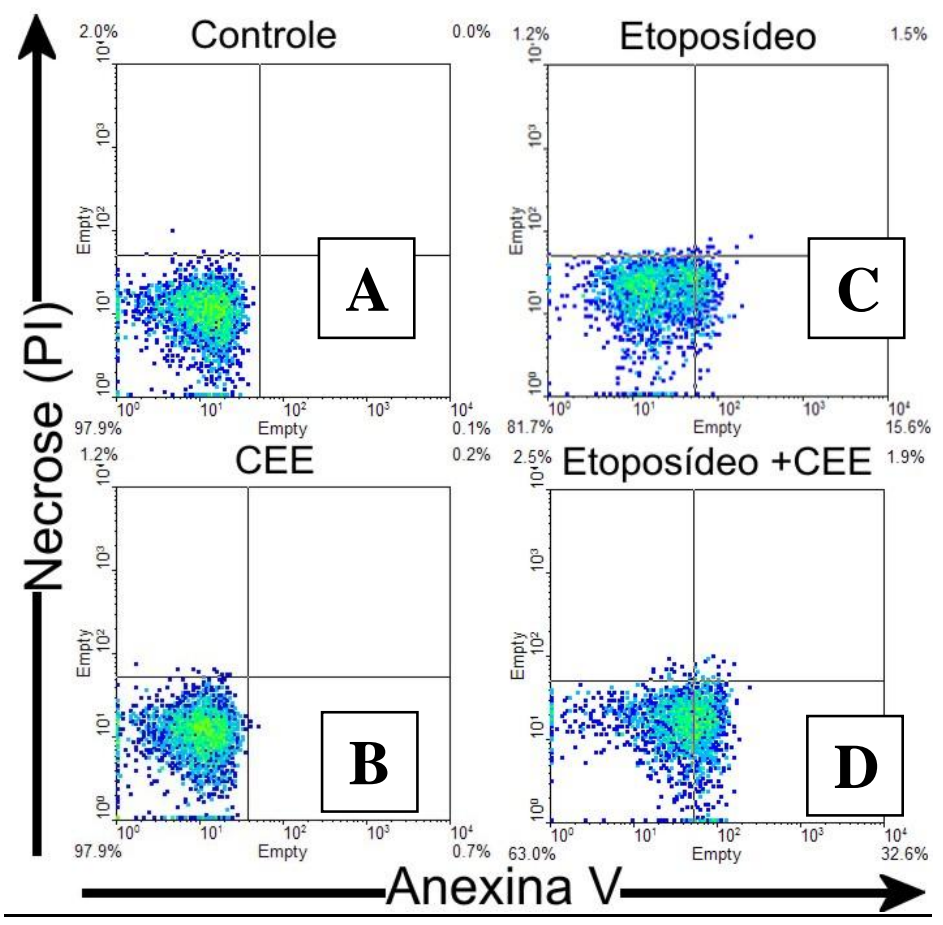

Imagens dos índices obtidos após 6 horas de exposição ao Etoposídeo (C) e combinado ao CEE (D). As imagens foram combinadas com a figura 4.15, permitindo visualizar o deslocamento pelo efeito do Etoposídeo (C e D) nas células com marcação para anexina V/PI. Na condição combinada do CEE (D) ocorre um deslocamento mais homogêneo em comparação ao Etoposídeo isolado (C).

Fonte: Próprio autor. 
Na figura 4.30 observa-se um expressivo deslocamento em direção do eixo X, indicando apoptose incial (presença de anexina V) nas células tratadas com Etoposídeo (C) e mais intensamente sob o efeito combinado com o CEE (D). A apoptose incial foi o tipo de morte predominante na ação combinada do Etoposídeo com o CEE no período de 6 horas (figura $4.32 \mathrm{~B}$ ).

Figura 4.30 - Imagens representativas de células FN1 marcadas com anexina V/PI.

\section{FN1}

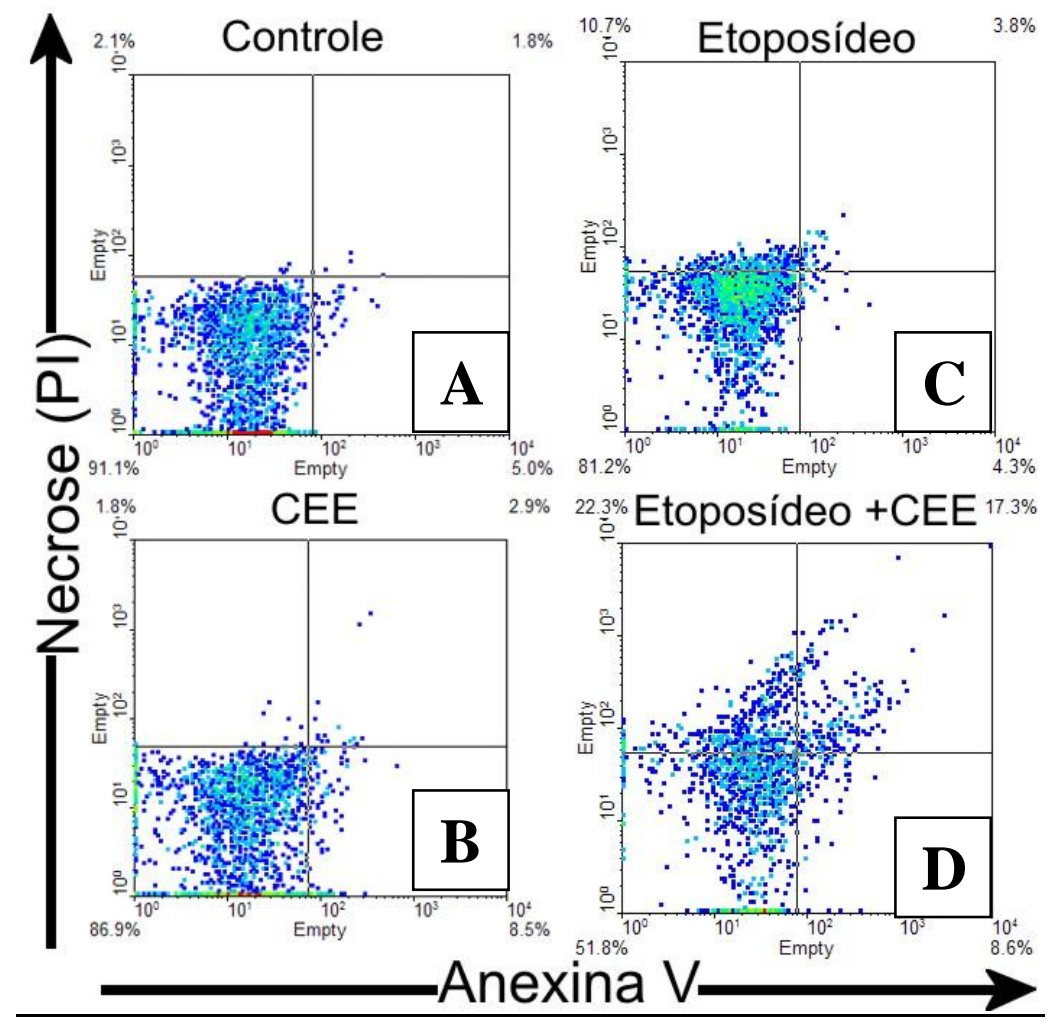

Imagens das células marcadas (anexina V/PI) para o período de 6 horas com o CEE (B e D) e Etoposídeo (C e D), indicando o aumento da mortalidade induzida pela ação combinada com o CEE. A figura foi combinada com as imagens da figura 4.16 para melhor visualização dos efeitos induzido pelo CEE e Etoposídeo.

Fonte: Próprio autor.

Diferente dos altos índices de apoptose inicial da linhagem B16F10, a mortalidade das células FN1 (figura 4.16) apresentou predominância de necrose e apoptose tardia, visível nas figuras pelo deslocamento dos pontos na diagonal (D). 
Figura 4.31 - Gráficos de células B16F10 marcadas com anexina V/PI nos grupos tratados com Etoposídeo.
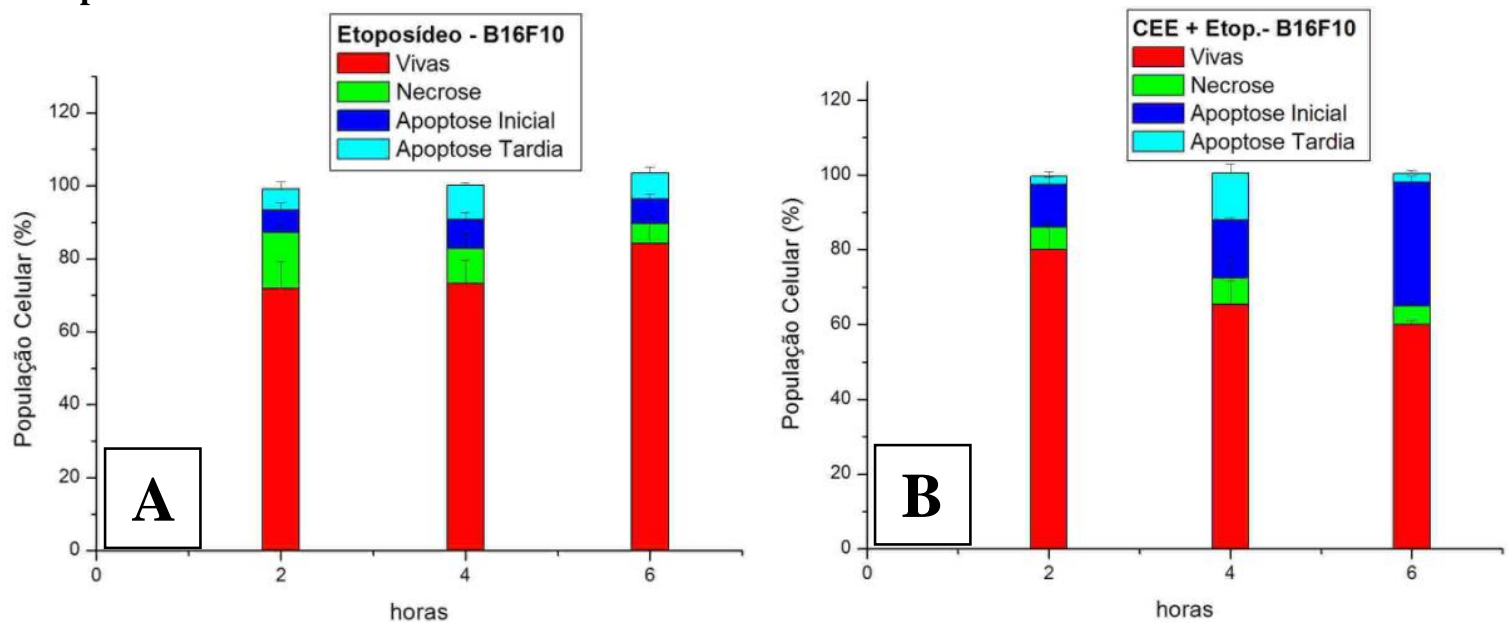

Valores resultantes da mortalidade induzida pela ação do quimioterápico Etoposídeo (A) e sua ação combinada com o CEE (B), nas células tumorais B16F10. A mortalidade induzida unicamente pelo Etoposídeo não favorece nenhum tipo de morte especificamente, em contraste com a ação combinada com o CEE.

Fonte: Próprio autor.

Figura 4.32 - Gráficos de células de FN1 marcadas com anexina V/PI nos grupos tratados com Etoposídeo.
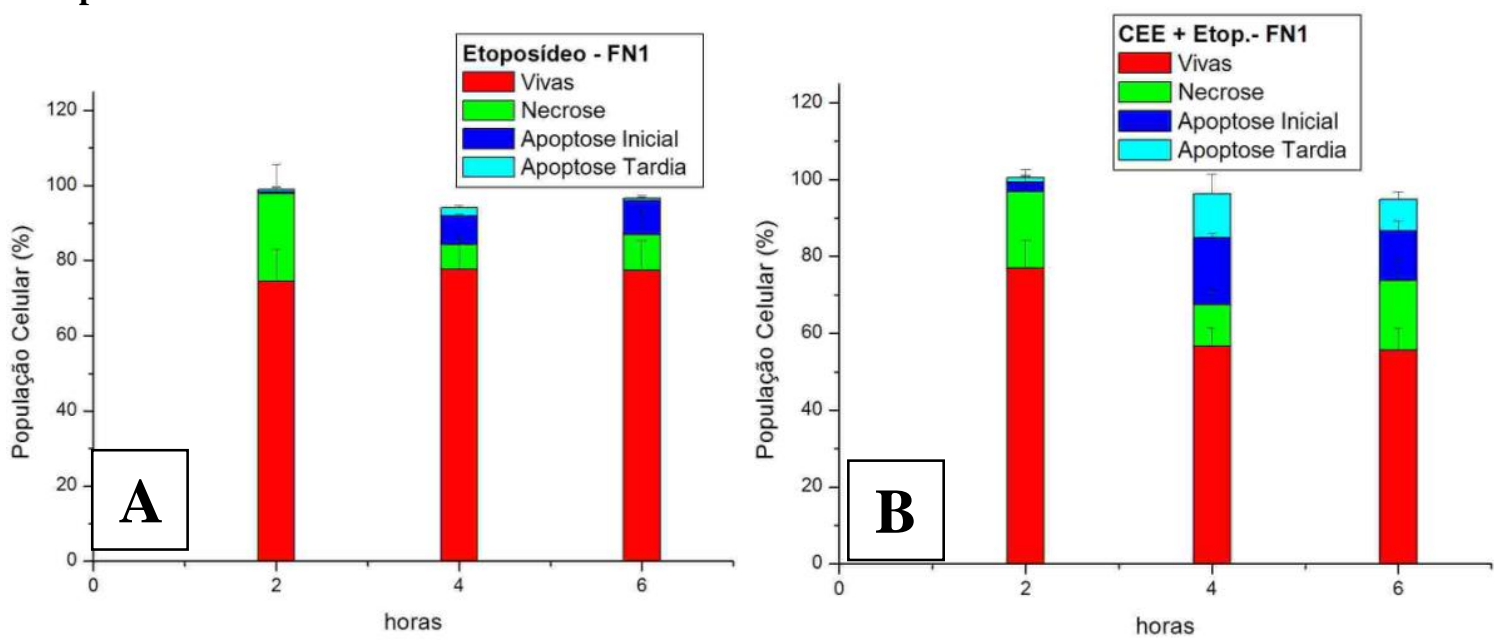

Valores da mortalidade induzida pelo efeito do Etoposídeo em células de fibroblasto FN1. Na mortalidade induzida pela ação combinada do quimioterápico com o CEE (B) ocorreu um aumento em todas as modalidades de morte mensuradas, sem haver predomínio de um tipo especifico de mortalidade.

Fonte: Próprio autor.

Nos gráficos das figuras 4.31 e 4.32 é possível detectar o aumento de morte celular pela ação do CEE (B), em contraste com a recuperação da viabilidade das células expostas apenas ao Etoposídeo (A). Os resultados são próximos aos obtidos com o marcador para caspase 3 fosforilada nos períodos de 4 e 6 horas. 


\subsubsection{Potencial de Membrana Mitocondrial com Etoposídeo e CEE}

Nas alterações do potencial de membrana, marcadas por rodamina 123, o efeito isolado do CEE foi bem próximo ao efeito combinado com o Etoposídeo para ambas as linhagens (figura 4.33 itens $\mathrm{C}$ e D).

Figura 4.33 - Histogramas das células marcadas com rodamina 123 para todos os grupos experimentais.
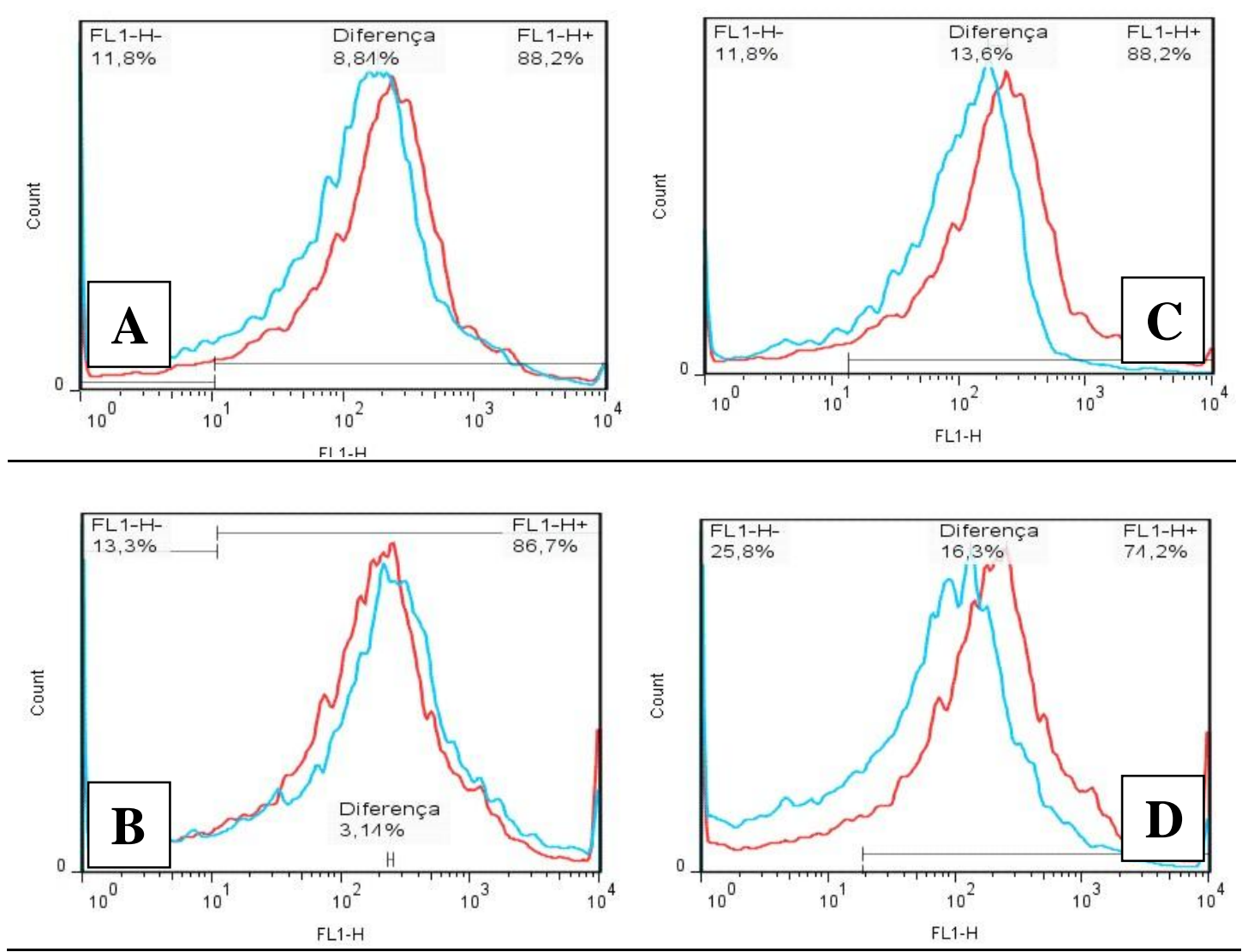

Imagens dos histogramas obtidas pelo programa WinMDI 2.8, da atividade mitocondrial das células B16F10 e FN1, expostas ao quimioterápico Etoposídeo por 6 h. Na figura A e B são apresentadas as curvas comparativas do controle (vermelho) com o curva do Etoposídeo (em azul). Em C e D estão presente as curvas comparativas do controle com a atividade combinada do Campo Elétrico Estático e Etoposídeo (em azul).

Fonte: Próprio autor. 
Figura 4.34 - Gráficos do potencial mitocondrial para todos os grupos experimentais.
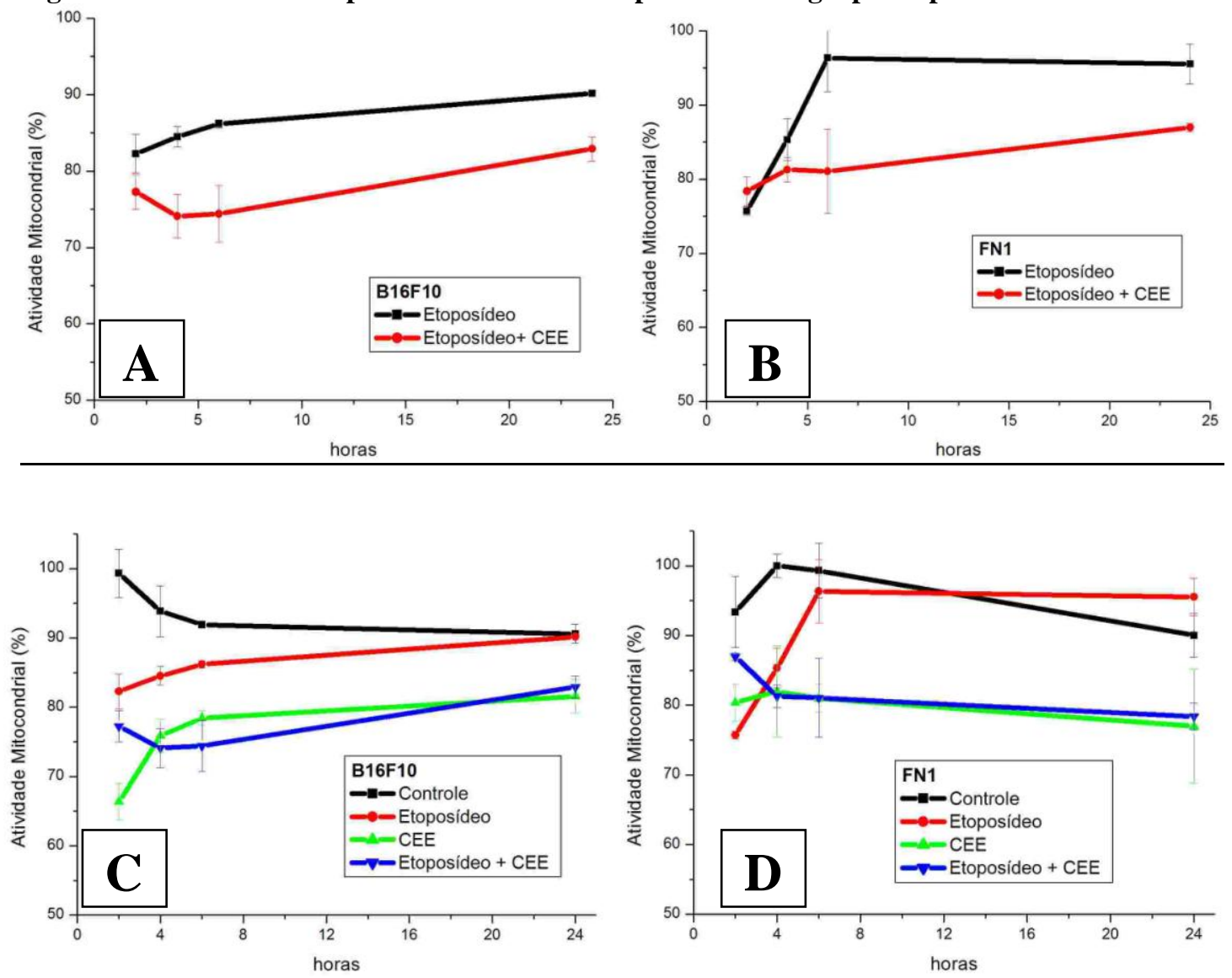

Valores da perda de atividade mitocondrial em função do tempo, comparando a ação do Etoposídeo e seu efeito concomitante com o Campo Elétrico em células B16F10 (A) e FN1 (B) e o comportamento das curvas com todos os grupos experimentais analisados (C e D).

Fonte: Próprio autor.

$\mathrm{Na}$ figura 4.34 estão presentes todos os grupos experimentais marcados pela rodamina 123 no potencial de membrana mitocôndrial. É possível notar que todos os grupos expostos ao CEE foram afetados, apresentando uma redução que independe da presença do Etoposídeo.

Nas figuras C e D, as curvas dos valores do Etoposídeo foram combinadas com as curvas do gráfico na figura 4.14 para se obter uma melhor visualização dos efeitos associados ao CEE. No caso do item “C”, referente à linhagem B16F10, é possível notar que o Etoposídeo apresenta uma queda na atividade mitocondrial (em relação a o grupo controle) para as primeiras horas do experimento. Esse valor diminui em função do tempo até igualar-se aos valores do controle. O efeito de redução do Etoposídeo apresentou um resultado similar aos demais marcadores porém, diferente dos outros resultados, sua presença em nada afetou a ação do CEE. 
5 DISCUSSÃO 


\subsection{Efeitos Isolados do Campo Elétrico Estático (CEE)}

\subsubsection{Efeitos do CEE na Viabilidade Celular}

Os resultados com as células expostas à ação isolada do CEE de $1000 \mathrm{~V} / \mathrm{cm}$ não apresentaram evidências de morte celular (figuras 4.11;4.13;4.14; 4.17 e 4.18) ou alterações morfológicas visíveis via microscopia óptica (figuras 4.1 a 4.2), exceção feita aos dados sobre a citotoxicidade via MTT (figura 4.8) e potencial da membrana mitocondrial via Rodamina 123 (figuras 4.14 e 4.34).

O resultado apresentando na figura 4.8 exibe uma redução média de $25 \%$ na viabilidade celular do MTT, e os resultados nas figura 4.14 e 4.34 mostram uma diminuição média de $15 \%$ na atividade mitocondrial, de forma constante no decorrer das horas avaliadas. Esses resultados estão presentes em todas as linhagens celulares, e no caso do potencial mitocondrial a redução está presente independentemente da presença do quimioterápico Etoposídeo (figura $4.34 \mathrm{C}$ e D). Como os demais experimentos com marcadores moleculares não identificaram nenhum tipo de morte celular por exposição ao CEE (figuras 4.11, 4.17 e 4.18), podemos deduzir que a redução observada na viabilidade da figura 4.8 é resultado de uma diminuição na proliferação celular, e/ou uma redução na atividade da enzima succinato desidrogenase (cuja atividade oferece o parâmetro de medida da viabilidade do MTT).

Os resultados que exibem alterações pela aplicação do CEE são diretamente relacionados à atividade mitocondrial, portanto é indicado analisar as possibilidades de como um campo elétrico afetaria a mitocôndria.

\subsubsection{Efeitos do CEE na Atividade Mitocondrial}

Entre os efeitos do CEE que podem ser significativos para alterar a atividade mitocondrial, o mais coerente é a alteração no transporte de íons $\mathrm{H}^{+}$entre as membranas mitocondriais. Qualquer íon será afetado pela ação do CEE, ficando sob a ação de uma força elétrica que o impele a movimentar-se na direção do campo. Contudo, esse efeito não apresentaria um resultado significativo na alteração do transporte de íons de uma membrana, pois à medida que o $\mathrm{CEE}$ reduz a velocidade dos íons que são liberados no sentido contrário ao campo, haverá um número equivalente de íons que será acelerado no sentido do CEE. Devido a isso, a velocidade final do fluxo de íons resulta em uma média constante, sem diferenças significativas na velocidade final dos íons livres. 
O equilibro acima descrito ocorre quando os íons afetados são cargas livres dentro de uma membrana. Porém, na mitocôndria, a maior parte dos íons e cargas do chamado "fluxo de elétrons" não está na condição de íons livres, mas associada a moléculas aderidas à membrana interna da mesma.

Figura 5. 1 - Transporte de íons na membrana mitocondrial.

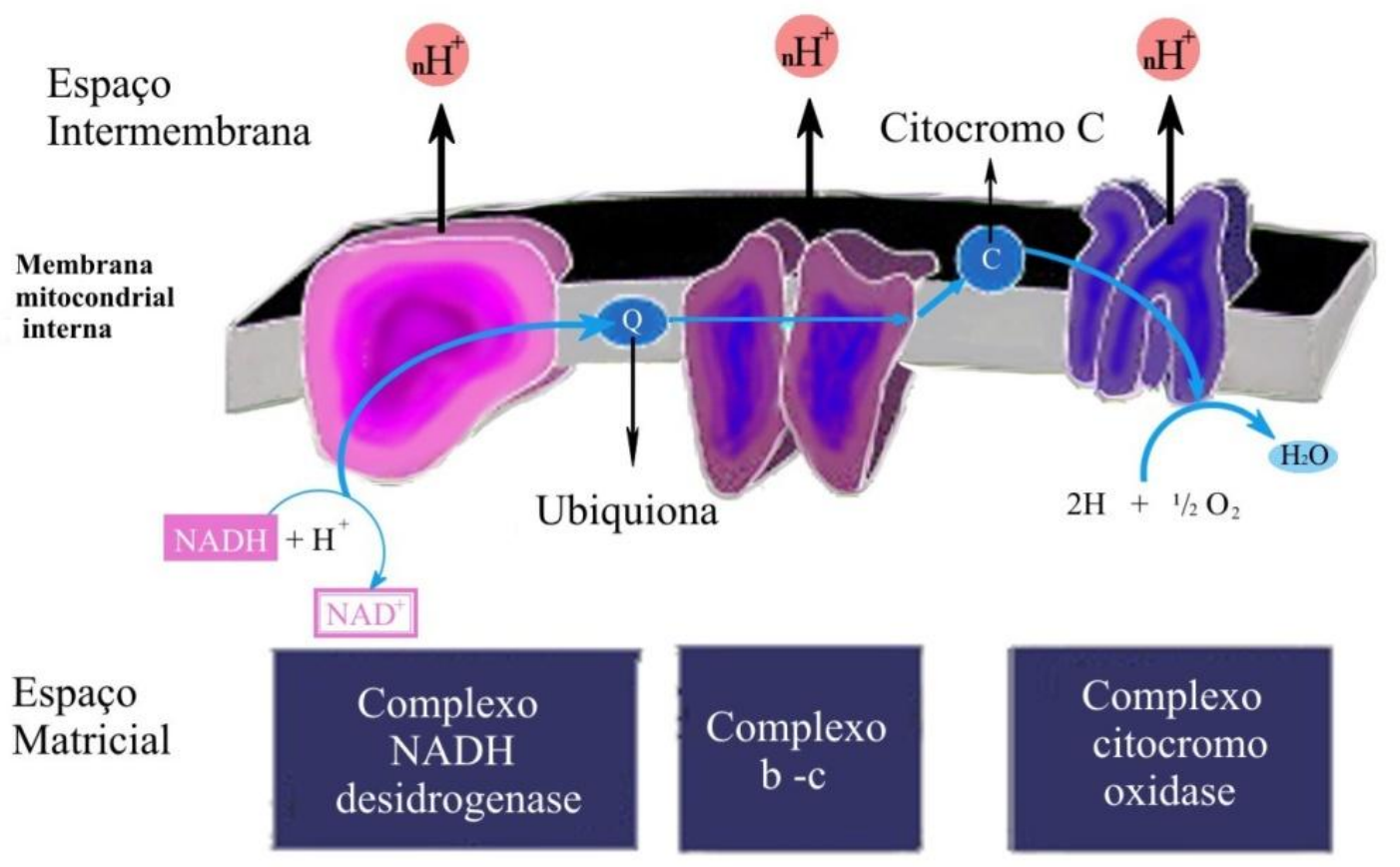

Representação do processo de transporte de íons $\mathbf{H}^{+}$, do espaço matricial para o espaço intermembrana, mediado pelos complexos.

Fonte: Próprio autor.

O fluxo de $\mathrm{H}^{+}$na membrana interna da mitocôndria tem inicio com o íon sendo transferido, por reações químicas entre moléculas que o mediam, até a saída dos complexos (no espaço intermembrana). Após passarem para o espaço intermebrana da mitocôndria, os íons de $\mathrm{H}^{+}$estão na sua forma livre (figura 5.1). Nessa condição (não associada a nenhuma outra molécula) os íons estarão sujeitos a ação da força elétrica gerada pelo CEE. 
Figura 5.2 - Orientação para a passagem de íons na membrana interna da mitocôndria.
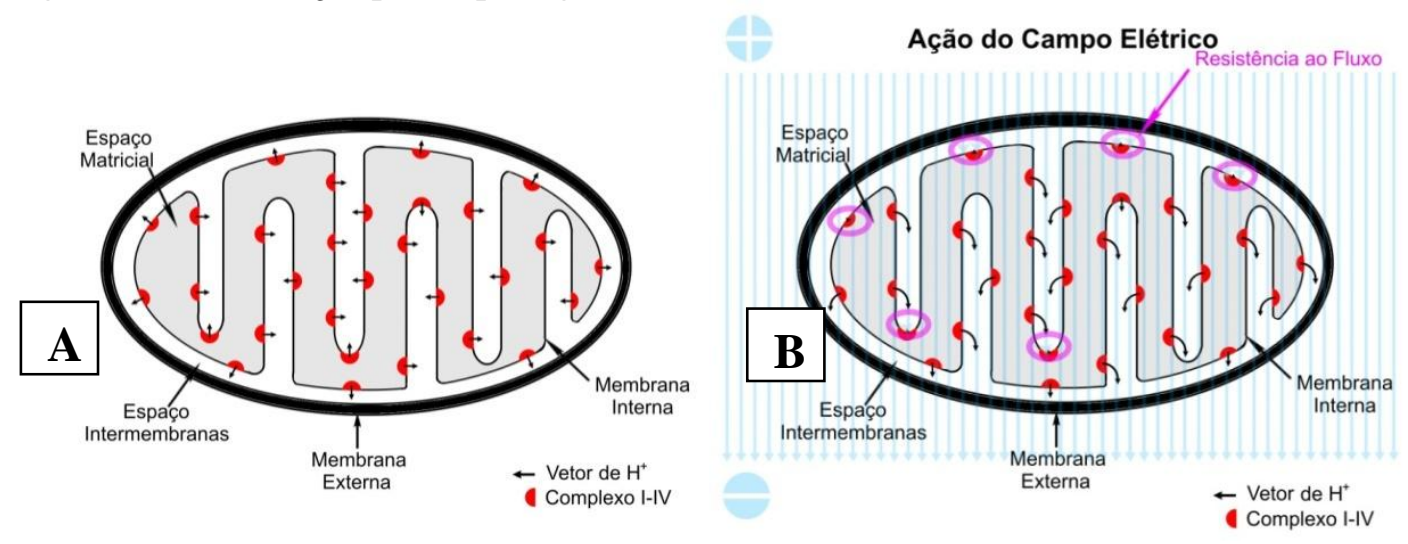

Representação esquemática da orientação para a passagem de íons da membrana interna da mitocôndria (em cinza) para o espaço intermembrana (em branco). As setas exibem os sentido dos íons em condições normais (A) e o sentido dos íons desviados pelo CEE (B).

Fonte: Próprio autor.

A disposição espacial das mitocôndrias nas células está orientada em todos os possíveis ângulos sólidos, entre $0 \mathrm{sr}$ e $4 \pi \mathrm{sr}$, assim como o sentido da liberação de íons de $\mathrm{H}^{+}$em seu interior (figura 5.2.A). Em uma fração desse ângulo espacial, o CEE poderá estar atuando em sentido oposto à velocidade de liberação dos íons $\mathrm{H}^{+}$, resultando na desaceleração desses íons (figura 5.2 B). Essa circunstância diminuiria o fluxo de $\mathrm{H}^{+}$para o espaço intermembrana, reduzindo a concentração de íons nessa região e, consequentemente, de ATPs produzidos na mitocôndria. Já os íons liberados no sentido do campo não serão beneficiados em sua orientação, pois a taxa de liberação de $\mathrm{H}^{+}$para o espaço intermembrana depende da velocidade das reações químicas nas proteínas dos complexos e compostos associados. Vale ressaltar que as enzimas e proteínas responsáveis por esse transporte são estruturas pesadas em comparação aos íons, e mesmo possuindo ocasionalmente uma carga íonica, não são afetadas pelo CEE de modo significativo como os íons $\mathrm{H}^{+}$. Os $\mathrm{H}^{+}$liberados no sentido contrário ao campo criam uma resistência para o transporte de novos íons, podendo afetar todo o processo do fluxo de elétrons, a atividade da succinato desidrogenase (no início do processo) e o transporte de cargas que dependem do transporte de $\mathrm{H}^{+}$(figura 5.3). 
Figura 5.3 - Efeito do Campo Elétrico Estático no transporte de íons.

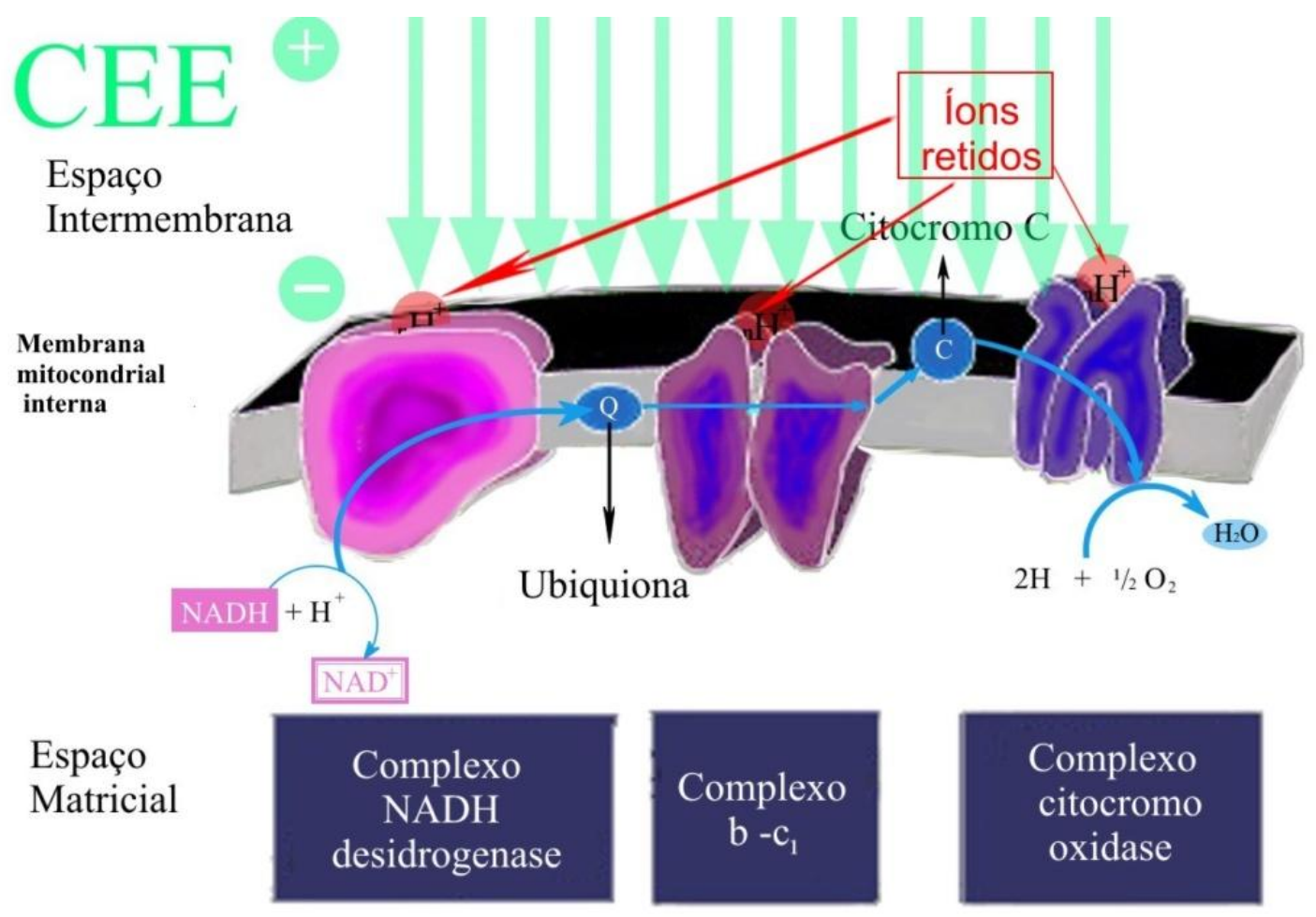

Representação da aplicação de um CEE no transporte de íons $\mathrm{H}^{+}$entre as membranas da mitocôndria, resultando da resistência a passagem de íons que estejam direcionados contra o sentido do campo.

Fonte: Próprio autor.

\subsection{Efeitos do CEE combinados com o Etoposídeo}

\subsubsection{Análise Qualitativa dos dados}

A análise das imagens coradas com vermelho neutro (figuras 4.4 a 4.6) não revelam alteraçõess morfologicas ou formação de vesículas decorrente da ação do CEE nas células. Nas células submetidas ao tratamento combinado do CEE com Etoposídeo (e apenas com Etoposídeo), foi possível identificar eventos de necrose e apoptose nas linhagens celulares analisadas (figuras 4.3, 4.5 e 4.7). A única diferença significativa entre as células com aplicação de Etoposídeo simultaneamente com o CEE, é intensa redução na densidade celular (figuras 4.1 e 4.2). Na condição do tratamento combinado (Etoposídeo mais CEE) é possível identificar, nitidamente, o aumento de mortalidade. Todos os eventos observados de forma qualitativa, através da microscopia de luz, puderam ser confirmados quantitativamente nos experimentos realizados. 


\subsubsection{Ação dos Quimioterápicos Combinados ao CEE}

Além do uso do Etoposídeo como quimioterápico padrão, o paclitaxel PFC foi utilizado nos estudos como um agente causador de danos distintos dos de DSBs. Em princípio, seu uso seria indicado para determinar a capacidade do CEE como agente polarizador de estruturas celulares. A ação do paclitaxel poderia ser somada a um possível torque elétrico aplicado pelo CEE aos microtúbulos, e o consequente aumento no desarranjo do citoesqueleto durante a mitose. Se isso ocorresse poderíamos averiguar se existiria uma ação do CEE em células sob quaisquer condições de estresse.

Os resultados apresentados na figura 4.21 mostram uma superposição das curvas de controle (somente com o paclitaxel) com aquelas combinadas com o CEE. É perceptível que não ocorre qualquer tipo de influência do campo combinado com a ação do paclitaxel. Ressaltamos que os pontos correspondentes aos valores zero do quimioterápico com CEE são inferiores aos da curva de controle, o que é coerente com os valores médios apresentados no gráfico da figura 4.8 Porém, esse efeito não se manifesta nos demais pontos da curva, mostrando que qualquer influência isolada do CEE não é somada ou atuante paralelamente ao efeito deste quimioterápico.

Esses resultados servem como controle negativo para os efeitos do CEE combinado com o outro agente citotóxico utilizado, visto que os efeitos do paclitaxel não geram DSBs. Neste caso, haveria evidências de que a geração de danos do tipo DSB é um fator expressivo na quantidade e qualidade dos resultados observados (Ver Introdução - 1.6).

Os resultados apresentados nas figuras 4.20 a 4.21 , via o método colorimétrico MTT, mostram um efeito supressor no crescimento celular quando há combinação dos efeitos do CEE com um agente gerador de DSBs. Para facilitar uma melhor apreciação dos resultados elaboramos o gráfico comparativo (para as duas linhagens) na figura 4.24, a partir da razão média dos resultados anteriores (figuras 4.21 A e B). Juntamente com a curva exponencial do gráfico na figura 4.22, fica bastante evidente que a combinação do Etoposídeo com o CEE gera um efeito sinergético.

\subsubsection{O Crescimento da Mortalidade Associado ao CEE}

A ação de polarização de proteínas livres pelo CEE é um fator com potencial para desencadear eventos de estresse celular ao inviabilizar a coordenação de eventos bioquímicos e metabólicos. Estes eventos dependem do deslocamento de proteínas dentro 
da célula e, portanto, sujeitos aos efeitos de torque induzidos pelo CEE. Entretanto, os efeitos isolados do CEE não indicam alterações dessa natureza, ou mesmo quando combinados por um agente quimioterápico que não gera danos do tipo DSB (como o paclitaxel), o CEE não apresenta uma interferência nas interações das vias bioquímicas associadas ao reparo. Por outro lado, todos os resultados sobre viabilidade e morte celular (figuras 4.24, 4.28 a 4.32), obtidos com a associação do campo com o Etoposídeo, indicam que a mortalidade celular dobrou em relação à taxa de mortalidade obtida apenas com o Etoposídeo.

A viabilidade celular (determinada via MTT), em função da concentração do Etoposídeo e com exposição ao $\mathrm{CEE}$, decresce acentuadamente com o aumento da concentração do quimioterápico. Para mensurar esse decréscimo ajustamos uma reta aos dados de viabilidade celular versus concentração do Etoposídeo (figura 4.21 - sem exposição ao CEE). Com base na reta obtida, determinamos o valor do "Índice Celular $50 \% ”\left(\mathrm{IC}_{50}\right)$. É importante salientar que, surpreendentemente, com a ação do CEE o comportamento linear não é mais verificado, razão pela qual foi necessário ajustar uma curva polinomial com um acentuado decréscimo. Contudo, devido às incertezas experimentais que ocorrem para viabilidades celulares iguais ou inferiores a aproximadamente $15 \%$, os resultados nessa região seriam mais compatíveis com um patamar (barras hachuradas no gráfico da figura 4.22 - com exposição ao CEE). Os resultados nos gráficos da figura 4.22 indicam que as concentrações necessárias para alcançar o $\mathrm{IC}_{50}$ decrescem de 0,46 mmol para 0,15 mmol em células FN1, e de 0,49 mmol para $0,20 \mathrm{mmol}$ em células $\mathrm{B} 16 \mathrm{~F} 10$, caracterizando uma drástica redução induzida pela ação do CEE. Vale a pena ressaltar mais uma vez, que com o quimioterápico paclitaxel a ação do CEE é inexistente quanto a alteração na viabilidade celular (figura 4.23).

As curvas de razão da viabilidade com tratamento de Etoposídeo e de Etoposídeo mais CEE, também apresentam uma queda acentuada, seguindo uma lei de potência (LAUBICHLER E MÜLLER, 2007), como no gráfico da figura 4.24. O aumento exponencial da mortalidade não pode ser definido, simplesmente, como um acréscimo de citotoxicidade devido ao $\mathrm{CEE}$, mas como resultado da interferência em um evento essencial para a reparação celular, revelando uma ação sinergética entre o quimioterápico e o campo elétrico. Observe-se que, enquanto no decaimento exponencial a função decresce assintoticamente a zero, na lei de potência a função decresce monotônicamente a zero (conforme ilustrado na figura 5.4). 
Figura 5.4 - Curvas com comportamento do decaimento exponencial e Lei de Potência.

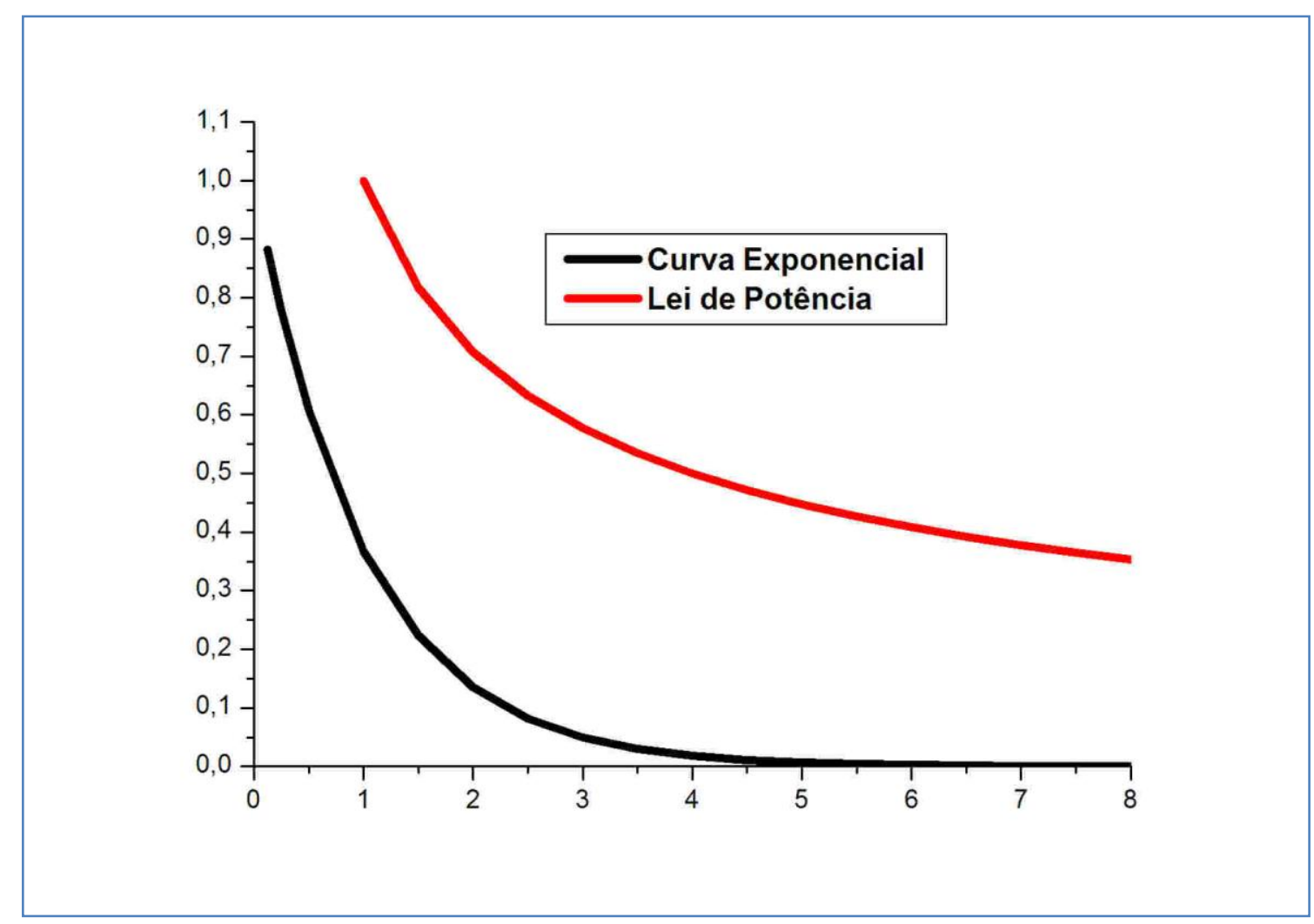

Curvas com comportamento do decaimento exponencial (em preto) e decaimento que caracteriza uma Lei de Pontência (em vermelho). A Curva Exponencial foi gerada a partir da função curva que descreve a Lei de Potência pela função

Fonte: Próprio autor.

A existência de uma lei de potência indica que o comportamento de um sistema dinâmico é inter conectado em uma rede complexa, ou grafos, cujas partes interagem de forma não-linear. Uma das propriedades marcantes de tais sistemas é a criticalidade, onde um evento específico influência outros eventos encadeados no sistema complexo. Desse modo, é possível ocorrer grandes transformações no sistema sem que haja uma influência direta em todos os seus componentes de modo a desencadear um estado crítico. Sistemas de redes simples, ligados de modo linear e contendo muitos corpos, apresentam correlações de curto alcance (como o movimento browniano), onde os eventos exibem um decaimento exponencial. Na criticalidade, no entanto, as correlações decaem lentamente, sem escala característica, temporal ou espacial. O comportamento observado segue uma lei de potência (figuras 4.22 e 4.24), indicando a ocorrência de um evento crítico na complexa rede enzimática de reparo. Se o efeito combinado do CEE com o Etoposídeo fosse unicamente uma interferência não específica em todas as proteínas envolvidas no reparo ou na manutenção celular, o comportamento das curvas nos gráficos de viabilidade e mortalidade decairia exponencialmente em toda sua extensão. Nesse caso, seria impossível 
ocorrer processos interdependentes de atividade enzimática, como os que caracterizam a apoptose, resultando na morte por necrose. Além disso, o efeito do CEE só se torna atuante quando há um dano gerador de DSBs, o que indica uma ação especifica em um evento chave nas vias bioquímicas utilizadas pela célula, como o que ocorre nas etapas iniciais de resposta celular a esse tipo de dano. Igualmente, o comportamento do aumento de mortalidade em função do tempo segue uma lei de potência (figura 4.16).

\subsubsection{Efeitos do CEE nas Moléculas de Reparo}

Descrevendo as etapas iniciais do reparo, lembremos que quimioterápico Etoposídeo atua na inativação da enzima de reparo Top2 (Ver Introdução - 1.3). Essa ação resulta na geração de danos do tipo DSB e um complexo processo de sinalização para efetuar o reparo. Com a presença de um dano do tipo DSB no DNA, são ativadas as proteínas de "checkpoint" e as vias efetoras de reparo, ocorrendo uma parada no ciclo celular e, talvez, a apoptose (KASTAN e BARTEK 2004; JACKSON e BARTEK 2009). Os "sensores de DNA" permitem a deteção do dano e se ligam à região danificada (ou próxima) do DNA ativando as proteínas envolvidas na reparação. Os sensores de DNA ativados pela topoisomerase, que consertam os danos ao DNA, incluem as ATM quinases, ATR e DNA-PK (POMMIER, 2006; NITISS, 2009, ROGOJINA, et al, 2011). O complexo DNA-PK (DNA - proteína quinase dependente) inicialmente liga as duas extremidades de uma quebra dupla, cada um em uma terminação rompida, e em seguida recruta as DNAPKCS. A próxima etapa é o recrutamento da ATM (Ataxia Telangiectasia Mutated) do citoplasma até o local danificado, onde irà associar-se com as regiões do DNA que flanqueiam a região rompida para se associarem com o complexo MRN (Mre11-Rad50Nbs1). A associação com o complexo MRN facilita a ativação completa da ATM e amplifica a localização do dano para identificar as quebras no DNA (BERKOVICH et al 2007;. LAVIN 2008). 
Figura 5.5 - Processo de sinalização na ativação da ATM.

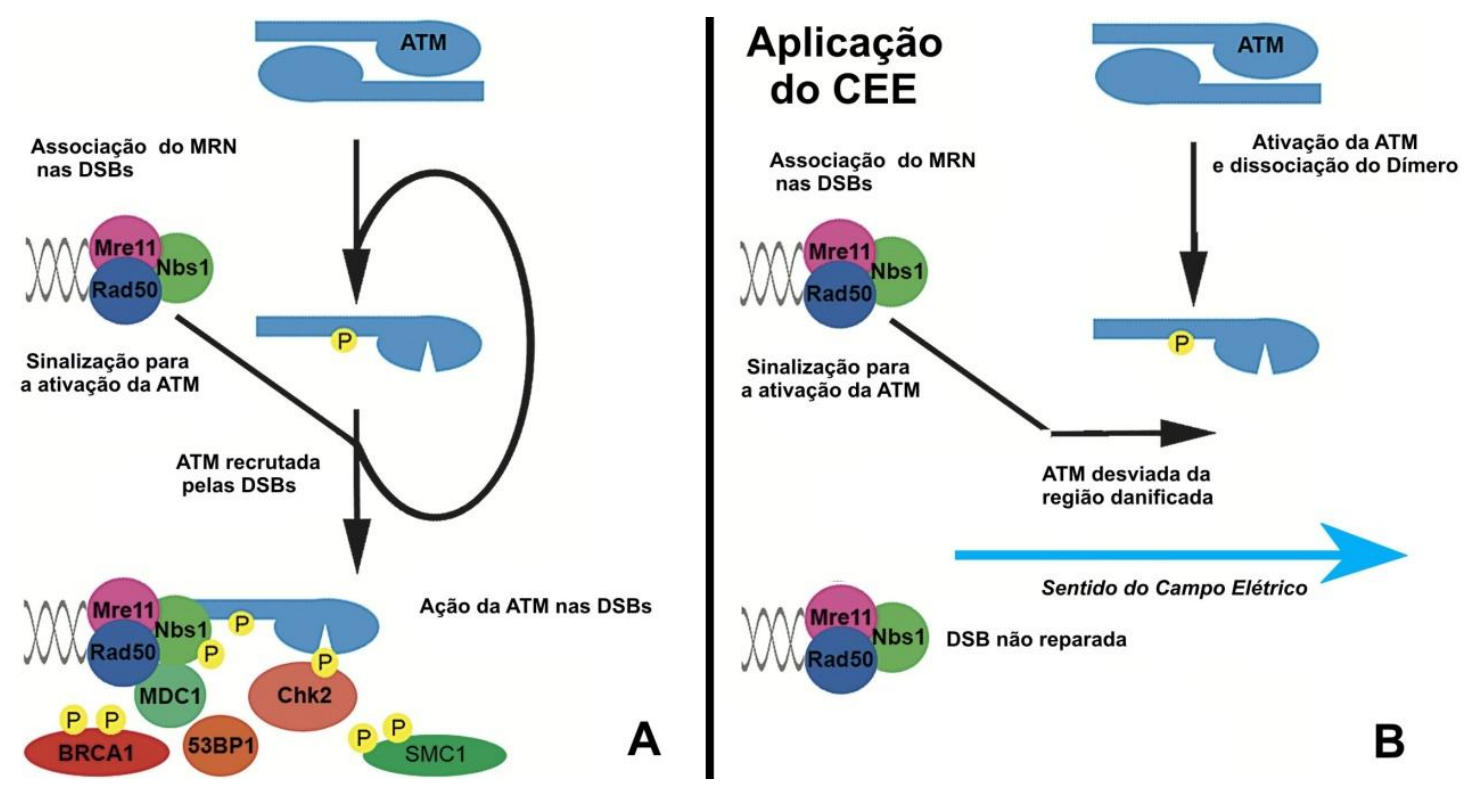

Representação esquemática do processo de sinalização na ativação da ATM a partir do dano DSB (A). A ligação entre os complexos ATM e MRN permite fortalecer o sinal para os marcadores na região de dano ao recrutar outras ATMs. A aplicação do Campo Elétrico Estático impede a ATM recrutada de alcançar a região do DSB (B), impedindo o reforço do sinal para a reparação e desencadeando a indução de morte celular.

Fonte: Adaptado de BAKKENIST e KASTAN, 2004.

Todos os processos acima descritos são realizados por proteínas livres, que dependem de um alinhamento adequado entre os complexos protéicos e as terminações rompidas no DNA. A ação do CEE polariza proteínas, e com isso dificulta a navegação e o alinhamento com a região do dano (figuras 1.5 e 5.5). Entretanto, se o CEE afetasse todas as vias de sinalização e reparo, haveria uma expressiva inibição do processo apoptótico, criando um acúmulo de DSBs que resultaria em necrose. Consequentemente, os resultados gráficos exibiriam curvas paralelas aos resultados do controle. Além desse evento não ocorrer, os resultados de apoptose e necrose via Caspase 3, Anexina V e PI (figuras de 4.28; 4.31 e 4.32) mostram que há um aumento significativo de apoptose em relação ao efeito isolado do Etoposídeo. Vale ressaltar que os eventos de aumento de mortalidade induzidos pelo CEE ocorrem após o período inicial de $2 \mathrm{~h}$ (figuras de 4.28; 4.31 e 4.32), indicando ser necessário, desde os primeiros instantes, um efeito acumulado de danos causados pelo quimioterápico para que o CEE seja efetivo (tanto que pelo resultado do gráfico na figura 4.25, o efeito do CEE é irrelevante após $2 \mathrm{~h}$ ). De fato, ao analisarmos os efeitos isolados do Etoposídeo, podemos identificar uma redução na apoptose e necrose após $2 \mathrm{~h}$ (figuras 4.31 e 4.32), efeito esperado devido à ação de reparo celular. Diferente da ação do quimioterápico isolado, o efeito combinado ao campo apresentou um aumento de 
mortalidade após as $2 \mathrm{~h}$ iniciais, sem redução subsequente. Essa constatação reforça o conceito de que o aumento da mortalidade deve-se à inibição dos eventos de reparo decorrentes da ação do CCE.

De todos os mecanismos desencadeados pela DSB possivelmente o recrutamento da ATM seria o mais afetado pela ação do CEE. Sua longa trajetória (comparada aos demais complexos envolvidos), do citoplasma até o núcleo em direção à região danificada, apresenta suscetibilidade à polarização e, consequentemente, um desvio de rota para a região alvo. Esse desvio dificulta a amplificação do sinal proveniente do sítio do dano, bem como sua precisa orientação espacial para efetivar o reparo. Esse resultado é endossado pelo gráfico na figura 4.25, mostrando que a ação do CEE é determinante nos momentos iniciais do dano gerado pelo Etoposídeo. O gráfico mostra que após 2 horas o efeito do campo se torna irrelevante estatisticamente, embora os demais resultados indiquem que a geração de danos celulares pelo Etoposídeo (figuras 4.28; 4.31 e 4.32) ainda continua intensa nesse período. Essa influência, ocorrendo entre a aplicação do Etoposídeo e do CEE, interfere significativamente nos instantes iniciais da resposta celular ao dano do tipo DSB. A necessidade de um curto intervalo de tempo (praticamente simultânea) entre a geração do dano do tipo DSB e a exposição ao CEE, é compatível com tempo de recrutamento da ATM em resposta ao dano. Após a ATM se ligar ao complexo MRN ocorre uma amplificação no sinal que identifica a localização do DSB, facilitando assim (ou mesmo permitindo totalmente) o processo de reparo mesmo sob a ação do CEE.

Resultados experimentais anteriores demonstraram que um campo elétrico aumenta a mortalidade celular em diversos organismos submetidos à radiação gama, (ARRUDANETO, 2009, 2010), incluindo a constatação de que há inibição de reparo no DNA. Esses resultados não puderam determinar se a ausência de reparo era uma ação direta ou consequência de outros eventos moleculares afetados pelo campo. O presente trabalho revela que a ação do CEE inibe o reparo celular ao dano do tipo DSB, sem afetar outros tipos de sinalização associadas à: divisão, manutenção e mecanismos de morte celular. Com a inibição dos processos de reparo a célula acumula danos no DNA induzindo respostas para os processos apoptóticos de morte celular, ou simplesmente os danos acumulam-se inibindo qualquer resposta da célula. Todas as ações de morte celular analisadas tiveram um aumento expressivo, sem favorecer especificamente um tipo de morte celular em função de outra, ocorrendo indistintamente aumentos nos eventos de 
necrose e apoptose inicial e tardia (figuras 4.31 e 4.32). Baseado nas evidências pode-se afirmar que a inibição do reparo pelo CEE atua em células danificadas por qualquer agente, físico ou químico, que promova dano na dupla fita do DNA.

\subsection{Destaques, Continuidade e Perspectivas Futuras}

\subsubsection{Destaques - Uso do CEE no Tratamento Tumoral}

1- O efeito de aumento na mortalidade celular, pela exposição combinada do Etoposídeo com o CEE, apresenta uma expressiva melhora no tratamento quimioterápico, indicando que os benefícios do tratamento combinado seriam aplicáveis em pacientes afligidos por tumores. A ação combinada não se restringe somente ao uso do Etoposídeo, mas encontra aplicação direta nos tratamentos radioterápicos e nos demais quimioterápicos que induzem morte celular por DSBs.

2- A aplicação do campo elétrico do tipo estático apresenta algumas vantagens sobre outros tratamentos que utilizam campos elétricos ou magnéticos pulsados. Tratandose de campos estáticos não há transferência de energia e, com isso, não há geração de calor, favorecendo exposições prolongadas nos tecidos.

Outra vantagem da aplicação do campo elétrico é poder restringir a área de aplicação na região alvo sem afetar as demais células do corpo. Essa vantagem permite tratar tumores com doses menores de quimioterápicos e radioterapia, minimizando os efeitos colaterais nas células fora da área exposta ao campo.

A tecnologia necessária é simples e de baixo custo, podendo facilmente ser adaptada para aplicações em tumores de diversos tamanhos. Sua construção necessita de materiais e técnicas bem conhecidas e largamente exploradas pelas indústrias de eletrônica direcionadas a equipamentos médicos.

O próximo passo para o uso de um tratamento combinado com o Campo Elétrico Estático são os testes in vivo, que permitirão o estudo de eficiência em condições biológicas dinâmicas e consequências nos tratamentos fracionados e de longo prazo. 


\subsection{2 $\quad$ Perspectivas futuras}

A biologia celular apresenta diversos processos e mecanismos biológicos a serem elucidados, tanto em microorganismos como em células humanas e suas correspondentes tumorais. Um fator pouco estudado, mas com grande interesse cientifico, são as propriedades elétricas e magnéticas presentes em estruturas como o DNA, microtúbulos e as mais diversas proteínas. Essas macromoléculas são reativas diretamente a correntes endógenas com reação pouco conhecida e aplicações inexploradas em tratamentos de saúde e pesquisa científica. O modelo biofísico apresentando na introdução (capitulo 1.6) enfatiza que há uma interação entre a eletricidade e macromoléculas, desencadeando eventos específicos (e muitas vezes seletivos) em determinadas funções e sinalizações biológicas. Ações induzidas por correntes de íons, campos magnéticos gerados pelo DNA, e efeitos descritos pela física quântica (como coerência e tunelamento), estão sendo identificados em processos biológicos fundamentais, escrevendo um novo capítulo na biologia (BALL, 2011). Estudos na área de física atômica e biologia molecular podem ser explorados de forma combinada permitindo desenvolver novas abordagens na tecnologia e tratamentos de saúde, como os realizados na atual pesquisa. 
6 CONCLUSÕES 


\subsection{Efeitos Isolados do Campo Elétrico Estático}

- A aplicação de um Campo Elétrico Estático de 1000 V/cm (CEE) em células de mamífero melanocíticas B16F10 e epitelial de fibroblasto humano FN1, não induzem mortalidade celular ou alterações morfológicas visíveis na microscopía ótica.

- As células estudadas, quando expostas ao CEE de $1000 \mathrm{~V} / \mathrm{cm}$, sofrem de redução no metabolismo mitocondrial, diminuindo o crescimento celular e o rendimento energético.

\subsection{Efeitos Combinados do CEE ao Etoposídeo}

- A associação do CEE com o quimioterápico etoposídeo aumenta sinergeticamente os efeitos de morte celular nas linhagens analisadas. Reduzindo drasticamente a concentração necessária de quimioterápico necessária para matar 50\% das células (alterando o $\mathrm{IC}_{50}$ ).

- Todas as ocorrências de morte celular analisadas tiveram aumento intensivo com o tratamento combinado do etoposídeo e do CEE, dobrando os valores de mortalidade.

- A exposição ao CEE nas células promove a inibição do reparo em danos gerados pelo etoposídeo desencadeiando a morte celular.

- Há uma indução constante de apoptose e morte celular durante todo o período de exposição ao campo elétrico combinado ao etoposídeo, em contraste com o efeito isolado do etoposídeo.

- O efeito do CEE atua especificamente no mecanismo de reparo associado aos danos na dupla fita do DNA (DSB).

- A ação do CEE no reparo ocorre nos momentos iniciais da geração do dano. Possivelmente o efeito está associado aos mecanismos de sinalização que antecedem o reparo.

- Todos os efeitos da exposição ao CEE atuam de forma indiferente a natureza celular, normal ou tumoral, possivelmente atuando de forma universal em todas as células. 


\section{REFERÊNCIAS}


ACEITUNO-MADERA. P.; BUENDÍA-EISMAN, A.; OLMO, F. J.; JIMÉNEZMOLEÓN, J. J.; SERRANO-ORTEGA, S. Melanoma, altitude, and UV-B radiation. Actas Dermosifiliogr. English, Spanish. v. 102, p.199-205, 2011.

ALBERTS, B.; JOHNSON, A.; LEWIS, J.; RAFF, M.; ROBERTS, K.; WALTER, P. Molecular Biology of the Cell. $5^{\text {th }}$ ed. New York and London: Garland Science, 2008. p. $1054-1055$.

AMBROSE, E. J.; JAMES, A. M.;, LOWICK, J. H. B. Differences between the electrical charge carried by normal and homologous tumour cells. Nature,v. 77: p. 576-577, 1956.

ARRUDA-NETO, J. D. T.; FRIEDBERG, E. ; BITTENCOURT-OLIVEIRA, M. C.; CAVALCANTE-SILVA, E.; SCHENBERG, A. C.; RODRIGUES, T.; GARCIA, F.; LOUVISON, M.; PAULA, C.; MESA, J.; MORON, M.; MARIA, D. A. ; GENOFRE, G. Static electric fields interfere in the viability of cells exposed to ionising radiation. Internat. J. Radiat. Biol. v. 85, p. 314-321, 2009.

ARRUDA-NETO, J. D. T.; FRIEDBERG; E. C.; BITTENCOURT-OLIVEIRA, M. C.; SEGRETO, H. R. C.; MORON, M. M.; MARIA, D. A.; BATISTA, L. F. Z.; SCHENBERG, A. C. G. The role played by endogenous and exogenous electric fields in DNA signaling and repair. DNA Repair v. 9, p. 356-357, 2010.

BAKKENIST, C. J.; KASTAN, M. B. Initiating Cellular Stress Responses. Cell, v. 118, p. 9-17, 2004.

BAKKENIST, C. J.; KASTAN, M. B. DNA damage activates ATM through intermolecular autophosphorylation and dimer dissociation. Nature, v. 421, n. 6922, p. 499-506, 2003.

BALCH, C. M.; BUZAID, A. C.; SOONG, S.J.; ATKINS, M. B.; CASCINELlI, N.; COIT, D. G.; FLEMING, I. D.; GERSHENWALD, J. E.; HOUGHTON, A. JR.; KIRKWOOD, J. M.; McMASTERS, K. M.; MIHM, M. F.; MORTON, D. L.; REINTGEN, D. S.; ROSS, M. I.; SOBER, A.; THOMPSON, J. A.; THOMPSON. J. F. Final Version of the American Joint Committee on Cancer Staging System for Cutaneous Melanoma, J Clin Oncol, v. 19, p. 3635 - 3648, 2001. 
BALDWIN, E. L.; OSHEROFF, N. Etoposide, Topoisomerase II, and Cancer. Curr Med Chem- Anticancer Agents, v. 5, p. 363-372, 2005.

BALL, P. Physics of life: The dawn of quantum biology. Nature v. 474, p. 272-274, 2011. |

BARASH, U.; COHEN-KAPLAN, V.; DOWEK, I.; SANDERSON, R. D.; ILAN, N.; VLODAVSKY, I. Proteoglycans in health and disease: new concepts for heparanase function in tumor progression and metastasis. FEBS J. v. 277, p. 19:3890-903, 2010.

BARDEESY, N.; BASTIAN, B. C.; HEZEL, A.; PINKEL, D.; DEPINHO, R. A.; CHIN, L. Dual Inactivation of RB and p53 Pathways in RAS-Induced Melanomas. Mol. Cell. Biol. v. 21 no. 6 2144-2153, 2001.

BARNHOLTZ-SLOAN, J. S.; SLOAN, A. E.; DAVIS, F. G.; VIGNEAU, F. D.; LAI, P.; SAWAYA, R. E. Incidence Proportions of Brain Metastases in Patients Diagnosed (1973 to 2001) in the Metropolitan Detroit Cancer Surveillance System. J Clin Oncol. v. 22, p. 2865-2872, 2004

BAUER, J.; BÜTTNER, P.; MURALI, R.; OKAMOTO, I; KOLAITIS, N. A.; LANDI, M. T.; SCOLYER, R. A.; BASTIAN, B. C. BRAF mutations in cutaneous melanoma are independently associated with age, anatomic site of the primary tumor, and the degree of solar elastosis at the primary tumor site. Pigment Cell Melanoma Res. v. 2, p. 345-351, 2011.

BENDER, R. P.; OSHEROFF, N. DNA topoisomerases as targets for the chemotherapeutic treatment of cancer. In: Checkpoint responses in cancer therapy, Dai $\mathrm{W}$ (ed), Totowa, N. J.: Humana Press, 2008, p. 57-91.

BERGER, M. F.; LEVIN, J. Z.; VIJAYENDRAN, K.; SIVACHENKO, A.; MAGUIRE, X. A. J.; JOHNSON, L.A.; ROBINSON,J. ; VERHAAK, R.G.; SOUGNEZ, C.; RONOFRIO, .C.; ZIAUGRA, L.; CIBULSKIS, K.; LAINE, E.; BARRETINA, J.; WINCKLER, W.; FISHER, D.E.; GETZ, G.; MEYERSON, M.; JAFFE, D. B.; GABRIEL, S.B.; LANDER, E.S.; DUMMER, R.; GNIRKE, A.; NUSBAUM, C.; GARRAWAY, L. A. Integrative analysis of the melanoma transcriptome. Genome Res. V. 20, p. 413-427, 2010.

BERGERS G.; BENJAMIN, L. E. Tumorigenesis and the angiogenic switch. Nat Rev Cancer. v.3, p. $401-410,2003$. 
BERKOVICH, E.; MONNAT, R. J. JR.; KASTAN, M. B. Roles of ATM and NBS1 in chromatin structure modulation and DNA double-strand break repair. Nat Cell Biol v. 9, p. 683-690, 2007.

BINGGELI, R.; WEINSTEIN, R. C. Membrane potentials and sodium channels: hypotheses for growth regulation and cancer formation based on changes in sodium channels and gap junctions. J. Theor. Biol. V. 123, p. 377-401, 1986.

BJORGE, J. D.; BRUCE, W. R.; MEEKER, B. E.; POWERS, W. E; VALERIOTE, F. A. Comparison of the doseand time-survival curves for normal hematopoietic and lymphoma colony-forming cells exposed to vinblastine, vincristine, arabinosylcytosine, and amethopterin. J. Natl Cancer Inst., 42, 1015, 1969.

CAMERON, I.L.; SUN, LU-ZHE; SHORT, N.; HARDMAN, W. E.; WILLIAMS, C. D. Therapeutic electromagnetic fields (TEMF) and gamma irradiation on human breast cancer xenograft growth, angiogenesis and metastasis. Cancer Cell Internat, v. 5, p. 1 - 23, 2005.

CHAMBERS, A. F.; GROOM, A.C.; MACDONALD, I. C. Dissemination and growth of cancer cells in metastatic sites. Nat Rev Cancer. v.2, p. 563 -572. 2002.

CHAMPOUX, J. J. DNA Topoisomerases: Structure, Function, and Mechanism. Annu Rev Biochem. v.70, p. 369-413, 2001.

CHAO L. H.; STRATTON M. M.; LEE, I. H.; ROSENBERG, O.S. LEVITZ, J.; MANDELL, D. J.; KORTEMME, T.; GROVES, J. T.; SCHULMAN, H.; KURIYAN J. A mechanism for tunable autoinhibition in the structure of a human $\mathrm{Ca} 2+/$ calmodulindependent kinase II holoenzyme. Cell. v.146, p. 732 - 745, 2011.

CHATTERJEE, D.; SCHMITZ, I.; KRUEGER, A.; YEUNG, K.; KIRCHHOFF, S.; KRAMMER, P. H.; PETER, M. E.; WYCHE, J. H.; PANTAZIS, P.. Induction of apoptosis in 9-nitrocamptothecintreated DU145 human prostate carcinoma cells correlates with de novo synthesis of CD95 and CD95 ligand and down-regulation of c-FLIP(short). Cancer Res, v. 61, p. 7148-7154, 2001.

CHINNAIYAN, A. M.; O'ROURKE, K.; TEWARI, M DIXIT, V. M. FADD, a novel death domain-containing protein, interacts with the death domain of Fas and initiates apoptosis. Cell, v. 81, p. 505-512, 1995. 
CHO, Y. S.; CHALLA, S.; MOQUIN, D.; GENGA, R.; RAY, T. D.; GUILDFORD, M.; CHAN, F, K. Phosphorylation-driven assembly of the RIP1-RIP3 complex regulates programmed necrosis and virus-induced inflammation. Cell, v. 137, p.1112 - 1123, 2009.

CHOI, H. J.; CHO, B. C.; SHIN, S .J.; CHEON, S. H., JUNG, J.Y.; CHANG, J.; KIM, S. K.; SOHN, J. H.; KIM, J. H. Combination of topotecan and etoposide as a salvage treatment for patients with recurrent small cell lung cancer following irinotecan and platinum first-line chemotherapy. Cancer Chemother Pharmacol, v.61, p. 309 - 313, 2008.

CIUSANI, E.; PEREGO, P.; CARENINI, N.; et al. Fas/CD95-mediated apoptosis in human glioblastoma cells: a target for sensitisation to topoisomerase I inhibitors. Biochem Pharmacol, v.63, p.881 - 887, 2002.

CRUCHTEN, S. V.; W. BROECK, V. Morphological and Biochemical Aspects of Apoptosis, Oncosis and Necrosis. Anat Histol Embryol. v. 31, p. 214 - 223, 2002.

DEGTEREV, A.; HUANG, Z.; BOYCE, M.; LI Y.; JAGTAP, P.; MIZUSHIMA N.; et al. Chemical inhibitor of nonapoptotic cell death with therapeutic potential for ischemic brain injury. Nat Chem Biol, v.1, p.112 - 119, 2005.

DIMRI, G. P. What has senescence got to do with cancer? Cancer Cell. v.7, p. $505-512$, 2005.

DOMBERNOWSKY, P., GEHL, J., BOESGAARD, M., PAASKE, T., JENSEN, B. V. Doxorubicin and paclitaxel, a highly active combination in the treatment of metastatic breast cancer. Semin Oncol. v. 23, p. 23 - 27, 1996.

EISCHEN, C. M.; KOTTKE, T. J. MARTINS, L. M.; BASI, G. S.; TUNG, J. S.; EARNSHAW, W. C.; LEIBSON, P. J.;, KAUFMANN, S. H. Comparison of apoptosis in wild-type and Fasresistant cells: chemotherapy-induced apoptosis is not dependent on Fas/Fas ligand interactions. Blood, v. 90, p.935 - 943, 1997.

FAUPEL, M.; VANEL, D.; BARTH, V.; DAVIES, R.; FENTIMAN, I. S.; HOLLAND, R.; LAMARQUE, J. L.; SACCHINI, V. AND SCHREER, I. Electropotential evaluation as a new technique for diagnosing breast lesions. Eur. J. Radiol, v.1, p.33 - 38, 1997.

FORBES, S. A.; BHAMRA, G.; BAMFORD, S.; DAWSON E.; KOK C.; CLEMENTS, J.; MENZIES A.; TEAGUE, J. W.; FUTREAL, P. A.; STRATTON, M. R. The Catalogue of 
Somatic Mutations in Cancer (COSMIC) Curr Protoc Hum Genet, v. 57, p. 10.11.110.11.26, 2008.

FROELICH-AMMON, S. .; BURDEN, D. A.; PATCHAN, M. W.; ELSEA, S. H.; THOMPSON, R.B.; OSHEROFF , N. Increased drug affinity as the mechanistic basis for drug hypersensitivity of a mutant type II topoisomerase. J Biol Chem, v, 270, p. 28018 28021, 1995a.

FROELICH-AMMON, S. J.; PATCHAN, M. W.; OSHEROFF, N.; THOMPSON, R. B. Topoisomerase II binds to ellipticine in the absence or presence of DNA: characterization of enzyme-drug interactions by fluorescence spectroscopy. J Biol Chem, v, 270, p. 14998$15005,1995 b$.

GALlUZZI, L.; MAIURI M. C.; VITALE, I.; ZISCHKA, H.; CASTEDO, M.; ZITVOGEL. L.; et al. Cell death modalities: classification and pathophysiological implications. Cell Death Differ, v.14, p. 1237 - 1243, 2007.

GALLUZZI, L; VITALE, I.; ABRAMS, J. M.; ALNEMRI, E.S.; BAEHRECKE, E.H.; BLAGOSKLONNY, M. V.; DAWSON, T. M.; DAWSON, V. L.; EL-DEIRY, W. S.; FULDA, S.; GOTTLIEB, E.; GREEN, D.R.; HENGARTNER, M.O.; KEPP, O. KNIGHT, R.A.; KUMAR, S.; LIPTON, S.A.; LU, X.; MADEO, F.; MALORNI, W.; MEHLEN, .; NUNEZ, G.; PETER, M.E.; PIACENTINI, M.; RUBINSZTEIN, D.C.; SHI, Y.; SIMON, H.U.; VANDENABEELE, P.; WHITE, E.; YUAN, J.; ZHIVOTOVSKY.; B. MELINO, G.; KROEMER, G. Molecular definitions of cell death subroutines: recommendations of the Nomenclature Committee on Cell Death, v. 19, p. 107 - 112, 2012.

GIROUARD, S. D.; LAGA, A. C.; MIHM, M. C.; SCOLYER, R. A.; THOMPSON, J. F.; ZHAN, Q.; WIDLUND, H. R.; LEE, C. W.; MURPHY, G. F. SOX2 contributes to melanoma cell invasion. Lab Invest, 2011.188, 2011.

GOGAS, H. J.; KIRKWOOD, J. M.; SONDAK, V. K. Chemotherapy for metastatic melanoma: time for a change? Cancer, v. 109, p. 455 - 464, 2007.

GRIFFIN-SOBEL, J. The war on cancer: victory or defeat? Nurs. Clin. North. Am, v. 43, p. $277-282,2008$. 
GRINDEM, C. B. Blood cell markers. Vet Clin. North. Am. Smal.l Anim Prac.t, v.26, p. 1043-1064, 1996.

GRISSOM, C. B. Magnetic Field Effects in Biology: A Survey of Possible Mechanisms with Emphasis on Radical-Pair Recombination. Chem. Rev, v. 95, p. 3 - 24, 1995.

GRIVICICH, I.; REGNER,A.; ROCHA, A. B. Morte Celular por Apoptose. Apoptosis: Programmed Cell Death. Rev. Bras. Cancerol., v. 53, p. 335 - 343, 2007.

HABER, J. E. Partners and pathways repairing a double-strand break. Trends Genet, v.16 p. $259-264,2000$.

HACKBARTH, J. S., MARINA GALVEZ-PERALTA, NGA T. DAI, DAVID A. LOEGERING, KEVIN L. PETERSON. Mitotic Phosphorylation Stimulates DNA Relaxation Activity of Human Topoisomerase I. J Biol Chem, v. 283, p.16711 - 16722, 2008.

HANAHAN, D.; WEINBERG, R. A.; The hallmarks of cancer: the next generation. Cell, v. 144 , p. $646-674.2011$.

HARTWELL, L. H.; KASTAN, M. B. Cell cycle control and cancer. Science, v. 266, p. $1821-1828,1994$.

HAYNES, R. H. The interpretation of microbial inactivation and recovery phenomena. Radiat. Res, v.6, p. 1 - 29, 1966.

HE, S. WANG, L.; MIAO, L.; WANG, T.; DU, F; ZHAO, L.; WANG, X. Receptor interacting protein kinase-3 determines cellular necrotic response to TNF-alpha. Cell, v.137, p. 1100-1111, 2009.

HENGARTNER, M. O. The biochemistry of apoptosis. Nature. v.407, p. 770 -776, 2000.

HITOMI, J.; CHRISTOFFERSON, D.E. N. G. A.; YAO, J.; DEGTEREV;, XAVIER, A, RJ.; et al. Identification of a molecular signaling network that regulates a cellular necrotic cell death pathway. Cell, v. 135, p. $1311-1323,2008$.

HSIANG Y.H.; LIHOU, M.G.; LIU, L.F. Arrest of replication forks by drug-stabilized topoisomerase I-DNA cleavable complexes as a mechanism of cell killing by camptothecin. Cancer Res, v. 49, p. 5077 - 5082, 1989. 
INCA - BRASIL. Ministério da Saúde. Secretaria de Atenção à Saúde. Instituto Nacional do Câncer. Coordenação de Prevenção e Vigilância. Estimativa 2008: Incidência de câncer no Brasil. Rio de Janeiro:, 2011. Disponível em http://www.inca.gov.br/estimativa/2008. Acesso em: 04 mar. 2011.

JACKSON, S.P. BARTEK. J. The DNA-damage response in human biology and disease. Nature, v. 461, p. $1071-1078,2009$.

JAKYMIW, A.; FUJITA, D. J. Selected glimpses into the activation and function of Src kinase. Oncogene, v.19, p. 5620 - 5635, 2000.

JOYCE, J. A. Therapeutic targeting of the tumor microenvironment. Cancer Cel, v. 7, p. $513-520,2005$.

KANNAN, K.; SHARPLESS, N. E.; XU, J.; O'HAGAN, R. C.; BOSENBERG, M.; CHIN, L. Components of the Rb pathway are critical targets of UV mutagenesis in a murine melanoma model. Proc Nati Acad Sci U S A, v. 100, p. 1221 - 1225, 2003.

KASTAN, .M. B.; BARTEK, J. Review article Cell-cycle checkpoints and cancer. Nature, v. 432 , p. $316-323,2004$.

KASTAN, M. B., LIM, D. S. The many substrates and functions of ATM. Nat. Rev. Mol. Cell Biol, v. 1, p. $179-186,2000$.

KERR J. F.; WYLLIE A. H.; CURRIE A. R. Apoptosis: a basic biological phenomenon with wide-ranging implications in tissue kinetics. Br J Cancer, v. 6, p. 239 - 257, 1972.

KIRSON, E. D. Alternating electric fields arrest cell proliferation in animal tumor models and human brain tumors. Proc. Nati. Acad. Sci. U S A, v. 104, p. 10152 - 10157, 2007.

KIRSON, E.; GURVICH, Z.; SCHNEIDERMAN, R.; DEKEL, E.; ITZHAKI, A.; WASSERMAN, Y.; SCHATZBERGER, R.; PALTI, Y. Disruption of cancer cell replication by alternating electric fields. Cancer Res, v. 64, p. 3288 - 3295, 2004.

KOESTER, S. T. K.; BOLTON, W. E. Intracellular markers, J Immunol Methods, v. 243, p. $99-106,2000$.

KOYAMA, S.; NAKAHARA, T.; SAKURAI, T.; KOMATSUBARA, Y.; ISOZUMI, Y.; MIYAKOSHI, J. Combined exposure of ELF magnetic fields and X-rays increased mutant 
yields compared with X-rays alone in pTN89 plasmids. J Radiat Res, v. 46, p. 257 - 262, 2005.

KROEMER, G.; GALLUZZI, L.; BRENNER, C. Mitochondrial membrane permeabilization in cell death, Physiol Rev, v. 87, p. 99 - 163, 2007.

KROEMER, G.; GALLUZZI, L.; VANDENABEELE, P. ;ABRAMS, J.; ALNEMRI, E.S.; BAEHRECKE, E.H.; et al. Classification of cell death: recommendations of the Nomenclature Committee on Cell Death 2009. Cell Death Differ; 16: 3-11, 2009.

LAUBICHLER, M. D.; MÜLlER, G. B.; Modeling Biology - Structures, Behavior, Evolution". Massachusetts, USA: The MIT Pres, 2007. p. 56-60.

LAVIN, M. F. Ataxia-telangiectasia: from a rare disorder to a paradigm for cell signalling and cancer. Nat Rev Mol Cell Biol, v. 9, p. 759 - 769, 2008.

LI, H.; ZHU, H.; XU, C. J.; YUAN, J. Cleavage of BID by caspase 8 mediates the mitochondrial damage in the Fas pathway of apoptosis. Cell, v. 94, p. $491-501,1998$.

LI, J.; HUANG, S.; ARMSTRONG, E. A.; FOWLER, J. F.; HARARI, P. M. Angiogenesis and Radiation response modulation after vascular endothelial growth factor receptor-2 (VEGFR2) blockade. Int J Radiation Oncology Biol Phys, v. 62, p. 1477 - 1485, 2005.

LI, X.; KOLEGA, J. Effects of direct current electric fields on cell migration and actin filament distribution in bovine vascular endothelial cells. J Vasc Res, v. 39, p. $391-404$, 2002.

LIEU, C.; CHOW, L.; PIERSON, A.; ECKHARDT, S.; O'BRYANT, C.; MORROW, M.; TRAN, Z.; WRIGHT, J.; GORE, L. A phase I study of bortezomib, etoposide and carboplatin in patients with advanced solid tumors refractory to standard therapy. Invest New Drugs, v. 27, p. $53-62,2009$.

LIU, L. F. DNA topoisomerase poisons as antitumor drugs. Annu Rev Biochem, v. 58, p. $351-375,1989$.

LOCKSHIN, R. A.; WILLIAMS, C. M. Programmed cell death - II. Endocrine potentiation ofthe breakdown of the intersegmental muscles of silkmoths. J Insect Physiol, v. 10 , p. $643-649,1964$. 
LOCKSHIN, R. A; WILliAMS, C. M. Programmed cell death - I. Cytology of degeneration in the intersegmental muscles of the pernyi silkmoth. J Insect Physiol, v. 11, p. $123-133,1965$.

LUO, X.; BUDIHARDJO, I.; ZOU, H.; SLAUGHTER, C.; WANG, X.Bid, a Bcl2 interacting protein, mediates cytochrome-c release from mitochondria in response to activation of cell surface death receptors. Cell v. 94, p 481 - 490, 1998.

MAHRHOFER, H.; BÜRGER, S.; OPPITZ, U.; FLENTJE, M.; DJUZENOVA C. S. Radiation induced DNA damage and damage repair in human tumor and fibroblast cell lines assessed by histone H2AX phosphorylation. Int. J. Radiation Oncology Biol. Phys., v. 64, p. $573-580,2006$.

MANIOTIS, A. J.; CHEN, C. S.; INGBER, D. E. Demonstration of mechanical connections between integrins, cytoskeletal filaments and nucleoplasm that stabilize nuclear structure. Proc Natl Acad Sci U S A, v. 94, p. 849 - 854, 1997.

MAZZANTI, M., BUSTAMANTE, J. O., OBERLEITHNER, H. Electrical Dimension of the Nuclear Envelope. Physiol Rev, v. 81, p. 1 - 19, 2001.

McCAIG, C. D.; SONG, B.; RAJNICEK, A. M.; Electrical dimensions in cell science. $J$ Cell Sci, v. 122, p. $4267-4276,2009$.

McCAIG, C. D.; RAJNICEK, A. M.; SONG, B.; ZHAO, A. M. Controlling Cell Behavior Electrically: Current Views and Future Potential. Physiol Rev, v. 85, p. 943 - 978, 2006.

McGILL M. A.; McGLAD, C. J. Cellular Signaling in: The basic science of oncology, Ian Tannock; book. 2005. p. $142-160$.

MEDEMA, J. P.; SCAFFIDI, C.; KISCHKEL, F. C.; et al. FLICE is activated by association with the CD95 death-inducing signaling complex (DISC). Embo J, v. 16, p. $2794-2804,1997$.

MEHLEN, P.; BREDESEN, D. E. Dependence receptors: from basic research to drug development. Sci Signal, v. 4, mr2, 2011.

MEIER, P.; FINCH, A.; EVAN, G. Apoptosis in development. Nature. 2000;407:796-801. MENENDEZ, J.A.; VELLON L.; LUPU, R. DNA topoisomerase II alpha (TOP2A) inhibitors up-regulate fatty acid synthase gene expression in SK-Br3 breast cancer cells: in 
vitro evidence for a 'functional amplicon' involving FAS, Her-2/neu and TOP2A genes. Int J Mol Med, v. 18, p. 1081 - 1087, 2006.

MERINO, E. J.; BOAL, A. K.; BARTON, J. K Biological contexts for DNA charge transport chemistry. Curr. Opin. Chem. Biol. v.12, p. 229 - 237, 2008.

MILLS, K. D.; FERGUSON, D. O.; ESSERS, J.;. ECKERSDORFF, M.; KANAAR, R, ALT, F. W. Rad54 and DNA Ligase IV cooperate to maintain mammalian chromatid stability. Genes Dev, v.18, p.1283 - 1292, 2004.

MÜLLER, M.; WILDER, S.; BANNASCH, D.; ISRAELI, D.; LEHLBACH, K.; LIWEBER, M.; FRIEDMAN, S. L.; GALLE, P. R.; STREMMEL, W.; OREN, M.; KRAMMER, P.H.. p53. activates the CD95 (APO-1/Fas) gene in response to DNA damage by anticancer drugs. J Exp Med, v. 188, p. 2033 -2045, 1998.

MURAD, F.J.; AUGUST, T.; LIU, L. F. - 1994 - 320 páginas MYCIELSKA, M.E., DJAMGOZ, M.B.A. Cellular mechanisms of direct-current electric field effects: galvanotaxis and metastatic disease. J Cell Sci, v. 117, p. 1631 - 1639, 2004.

NATIONAL CANCER INSTITUTE. Physician Data Query (PDQ). Melanoma Treatment. Accessed at www.cancer.gov/cancertopics/pdq/treatment/melanoma/HealthProfessional on April 8, 2011.

NELSON, C. M.; BISSELL, M. J. Modeling dynamic reciprocity: engineering threedimensional culture models of breast architecture, function, and neoplastic transformation. Semin Cancer Biol, v. 15, p. 342 - 352, 2005.

NISHI, R.; SUGASAWA, K. Repair mechanism of UV-induced DNA lesions. Tanpakushitsu Kakusan Koso, v. 51, p. 2126 - 2133, 2006.

NITISS, J. L. DNA topoisomerase II and its growing repertoire of biological functions. Nat Rev Cancer, v. 9, p. $327-337,2009$ a.

NITISS, J. L. Targeting DNA topoisomerase II in cancer chemotherapy. Nat Rev Cancer, v. 9 , p. $338-350,2009$ b.

NUCCITELLI, R.; CHEN, X.; PAKHOMOV, A. G.; BALDWIN, W. H.; SHEIKH, S.; POMICTER, J. L.; REN, W.; OSGOOD, C.; SWANSON, R. J.; KOLB, J. F.; BEEBE, S. J.; SCHOENBACH, K. H.. A new pulsed electric field therapy for melanoma disrupts the 
tumor's blood supply and causes complete remission without recurrence. Int. J. Cancer, v. 125 , p. $438-445,2009$.

NUCCITElli, R., PliQUeTt, U., CHEN, X., FORD, W., JAMES SWANSON, R., BEEBE, S. J.; KOLB, J. F.; SCHOENBACH, K. H. Nanosecond pulsed electric fields cause melanomas to self-destruct. Biochem Biophys Res Com, v. 343, p. 351 - 360, 2006.

OHKAWA, H., OHISHI, N.; YAGI, K. Assay for lipid peroxides in animal tissues by thiobarbituric acid reaction. Anal Biochem, v. 95, p. 351 - 358, 1979.

OKADA, H.; MAK, T. W. Pathways of apoptotic and non-apoptotic death in tumour cells. Nat Rev Cancer, v. 4, p. 592 - 603, 2004.

OSTMAN, A.; MICKE, P. Tumour-stroma interaction: cancer-associated fibroblasts as novel targets in anti-cancer therapy? Lung Cancer, v. 45, p. 163 - 175, 2004.

PAPETTI, M.; HERMAN, I. M. Mechanisms of normal and tumor-derived angiogenesis. Am J Physiol Cell Physiol, v. 282, p. 947 - 970, 2002

PAWLIK, T. M.; SONDAK, V. K. Malignant melanoma: current state of primary and adjuvant treatment. Crit Rev Oncol Hematol, v. 45, p. 245 - 264, 2003.

POMMIER, Y. Topoisomerase I inhibitors: camptothecins and beyond. Nat Rev Cancer, v. 6, p .789-802, 2006.

POMMIER, Y.; LEO, E.; ZHANG, H.; MARCHAND, C. DNA topoisomerases and their poisoning by anticancer and antibacterial drugs. Chem Biol, v. 17, p. 421 - 433, 2010.

PRIEL, A.; RAMOS, A. J.; TUSZYNSKI, J. A.; CANTIELlO, H. F. A biopolymer transistor: Electrical amplification by microtubules. Biophys. J. v. 90, p. 4639 - 4643, 2006.

RAMSAY, J.; BIRRELL, G. Normal tissue radiosensitivity in breast cancer patientes. Int. J. Radiation Oncology Biol. Phys., v. 31, p. 339 - 344, 1995.

RANGANATH R. M.; NAGASHREE N. R. Role of programmed cell death in development. Int Rev Cytol, v. 202, p.159 - 242, 2001. 
REPACHOLI, M. H.; GREENEBAUM, B. Interaction of Static and Extremely Low Frequency Electric and Magnetic Fields with Living Sytems: Health Effects and Research Needs. Bioelectromagnetics, v. 20, p. 133 - 160, 1999.

RESNICK, M. A.; GAME, J. C.; STASIEWICZ, S. Genetic Effects of UV Irradiation on Excision-Proficient and -Deficient Yeast During Meiosis. Genetics, v. 104, p. $603-818$ Aug. 1983.

ROBINSON, M. J.; MARTIN, B. A.; GOOTZ, T. D.; McGUIRK, P. R.; NEIL OSHEROFF. Effects of Novel Fluoroquinolones on the Catalytic Activities of Eukaryotic Topoisomerase II: Influence of the C-8 Fluorine Group. Antimicrobial Agents and Chemotherapy, v. 36, p. $751-756,1992$.

ROBINSON, M. J.; OSHEROFF. N. Effects of antineoplastic drugs on the post-strandpassage DNA cleavage/religation equilibrium of topoisomerase II. Biochemistry, v. 30, p. $1807-1813,1991$.

ROGOJINA, A.; GAJEWSKI, S.; BAHMED, K.; OSHEROFF, N; NITISS, J. L. Topoisomerase II Inhibitors: Chemical Biology. IN: POMMIER, Y. DNA Topoisomerases and Cancer. New York: Human Press, 2011. p. 211 - 224.

ROITT, I.; BROSTOFF J.; MALE, D. Sistema linfóide. In: ROITT, I. M., BROSTOFF, J. Imunologia, 1ed. São Paulo: Manole, 1999. p. 31 - 41

ROWINSKY, E. K.; CAZENAVE,; L. A.; DONEHOWER, R. C. Taxol: A Novel Investigation . J Natl Cancer Inst, v. 82, p. 1247 - 1259, 1990.

SALEH, A.; SRINIVASULA, S. M.; ACHARYA, S. et al. Cytochrome c and dATPmediated oligomerization of Apaf-1 is a prerequisite for procaspase-9 activation. $J$ Biol Chem, v. 274, p. $17941-17945,1999$.

SALVESEN, G. S.; DIXIT, V.M. Caspase activation: The induced-proximity model. Proc Natl Acad Sci U S A, v. 96, p. 10964 - 10967, 1999.

SAUTÈS-FRIDMAN, C.; CHERFILS-VICINI J.; DAMOTTE, D.; FISSON S.; FRIDMAN W. H.; CREMER, I.; Dieu-Nosjean M.C. Tumor microenvironment is multifaceted. Cancer Metastasis Rev, v. 30, p.13 - 25, 2011. 
SCAFFIDI, C.; FULDA, S.; SRINIVASAN, A.; FRIESEN, C.; LI, F.; TOMASELLI, K. J.; DEBATIN, K. M.; KRAMMER, P. H.; PETER, M. E. Two CD95 (APO-1/Fas) signaling pathways. Embo J, v. 17, p 1675 - 1687, 1998.

SCHUTZE, S.; TCHIKOV, V.; SCHNEIDER-BRACHERT W. Regulation of TNFR1 and CD95 signalling by receptor compartmentalization. Nat Rev Mol Cell Biol, v. 9, p. 655 $662,2008$.

SCHWEICHEL, J. U.; MERKER, H. J. The morphology of various types of cell death in prenatal tissues. Teratology, v. 7, p. $253-266,1973$.

SHAO, R. G.; CAO, C. X.; NIEVES-NEIRA, W.; DIMANCHE-BOITREL, M. T.; SOLARY, E.; POMMIER, Y.Activation of the Fas pathway independently of Fas ligand during apoptosis induced by camptothecin in p53 mutant human colon carcinoma cells. Oncogene 20:1852-1859; 2001.

SHARPLESS, N. E.; KANNAN, K.; XU, J.; BOSENBERG, M. W.; CHIN, L. Both products of the mouse Ink4a/Arf locus suppress melanoma formation in vivo. Oncogene, v. 22 , p. $5055-5059,2003$.

SONG, B.; ZHAO, M.; FORRESTER, J. V.; McCAIG, C. D. Electrical cues regulate the orientation and frequency of cell division and the rate of wound healing in vivo. Proc. Natl. Acad. Sci. U S A, v. 99, p. 13577 - 13582,

SPORN, M. B. The war on cancer. Lancet, v. 347, p. 1377 - 1381, 1996.

STARK, M.; HAYWARD, N. Genome-Wide Loss of Heterozygosity and Copy Number Analysis in Melanoma Using High-Density Single-Nucleotide Polymorphism Arrays. Cancer Res, v. 67, p. 2632 - 2642, 2007.

STRATTON, M. R.; CAMPBELL, P. J.; FUTREAL, P. A. The cancer genome. Nature, $458,719-724,2009$.

STUART, D.; SELLERS W. R. Linking somatic genetic alterations in cancer to therapeutics. Curr Opin Cell Biol, v. 21, p. 304 - 310, 2009.

TUSZYNSKI, J. A.; PORTET, S., DIXON, J. M.; LUXFORD, C.; CANTIELLO, H. F. Ionic wave propagation along actin microfilaments. Biophys J, v. 86, p. 1890 - 1903, 2004. 
VANDENABEELE, P.; GALLUZZI, L.; VANDEN, T. B.; KROEMER, G. Molecular mechanisms of necroptosis: an ordered cellular explosion. Nat Rev Mol Cell Biol, v. 11, p. $700-714,2010$.

VERBORG, W. A.; CAMPBELL, L. R.; HIGHLEY, M. S.; RANKIN, E. M. Int $J$ Gynecol Cancer, v. 18, p .228-234, 2008.

VOET, D.; VOET, J. G.; PRATT, C. W. Fundamentals of Biochemistry. 2ed.. New York: John Wiley and Sons, Inc, 2006. P. 547 - 548.

WAINSTEIN, A. J.; BELFORT, F. A. Conduta para o melanoma cutâneo. Rev Col Bras Cir, v. 3, p. $204-214,2004$.

WAJANT, H. The Fas signaling pathway: more than a paradigm. Science, v. 296, p. 16351636.

WALKER, J. V.; NITISS, J. L. DNA topoisomerase II as a target for cancer chemotherapy. Cancer Invest, v. 20, p. 570 - 589, 2002.

WANG ,Y.; REVELO, M. P.; SUDILOVSKY, D. Development and characterization of efficient xenograft models for benign and malignant human prostate tissue. Prostate, v. 64, p. $149-159.2005$.

WANG, J. C. Cellular roles of DNA topoisomerases: a molecular perspective. Nat Rev Mol Cell Biol, v. 3, p. 430 - 440, 2002.

WANG, E.; REID, B.; LOIS, N.; FORRESTER, J. V.; McCAIG, C. D.; ZHAO, M. Electrical inhibition of lens epithelial cell proliferation-An additional factor in secondary cataract? FASEB J, v.19, p. $842-844,2005$.

WANG, E., YIN, Y., ZHAO, M., FORRESTER, J. V. AND McCAIG, C. D. Physiological electric fields inhibit proliferation of vascular endothelial cells by block at G1. FASEB J. 17, 458-460, 2003.

WANG, Z. B.; LIU ,Y. Q.; CUI, Y. F. Pathways to caspase activation. Cell Biol Int. v. 29, p. $489-196,2005$. 
WEVER, O.; MAREEL, M. Role of tissue stroma in cancer cell invasion. J Pathol. v. 200, p. $429-447,2003$.

YU, S. P.; CHOI, D. W. Ions, cell volume, and apoptosis. Proc Natl Acad Sci U S A, v. 97, p. $9360-9362,2000$.

YU, Z. G.; SONG, X. Variable range hopping and electrical conductivity along the DNA double helix. Physl Rev Lett, v.86, p. 6018 - 6021, 2001.

ZHANG, D. W.; SHAO, J.; LIN, J.; ZHANG, N. LU, B. J.; LIN, S. C.; et al. RIP3, an energy metabolism regulator that switches TNF-induced cell death from apoptosis to necrosis. Science. v. 325, p. 332-336, 2009.

ZIEGLER, U.; GROSCURTH, P. Morphological features of cell death. News Physiol Sci, v. 19, p. $124-28,2004$. 
APÊNDICE 


\section{A.1. Cálculo empregado para determinação dos valores obtidos no teste de crescimento celular via MTT}

O cálculo para obtenção da viabilidade celular em porcentagem a partir dos valores em absorbância é dado por:

$$
\text { Viabilidade }(\%)=(L-B) * 100
$$

C

onde $L$ é a absorbância obtida da amostra analisada, $B$ é absorbância obtida do meio de cultura sem célula e $C$, a absorbância do controle (células não-irradiadas, sem quimioterápicos e sem exposição aos campos exógenos). Todas as tabelas são representativas das médias dos valores obtidos das réplicas (4, 6 ou 8 amostras para cada ponto), considerando os valores dentro do desvio padrão para a determinação da variância.

\section{A.2. Cálculo da Variância empregado como margem de erro entre os valores experimentais}

A Variância Total (V) foi obtida quando as amostras "X" de vários experimentos foram reunidas, com $n=$ Número elementos obtidos.

A média desse conjunto é simbolizada $\bar{X}$ por e pode ser expressa por:

$$
\mathrm{V}=\frac{\sum\left(x-\bar{x}^{2}\right)}{4}
$$

sendo que $\mathrm{V}$ mede a variação entre todas as amostras reunidas. 


\section{A.3. Valores dos experimentos com o Campo Elétrico Estático Isolado}

Tabela A.1 - Valores referentes à influência do CEE na Viabilidade Celular - via MTT- comparados ao respectivo controle (determinado em $100 \%$ ), graficamente representados no gráfico 4.1.

\begin{tabular}{lll}
$\begin{array}{ll}\text { Linhagem } \\
\text { Celular }\end{array}$ & CEE \% & Variância \% \\
\hline B16F10 & 88,7 & 8,7 \\
FN1 & 70,5 & 3,0 \\
\hline
\end{tabular}

Tabela A.2- Valores referentes à influência do CEE isolado em células marcadas para Caspase 3, graficamente representados no gráfico 4.2, como B16F10 (A) e FN1 (B).

\begin{tabular}{ccccccccc}
\hline \multirow{2}{*}{ Tempo } & \multicolumn{4}{c}{ B16F10 \% } & \multicolumn{4}{c}{ FN1 \% } \\
(horas) & Controle & var & CEE & var & Controle & var & CEE & var \\
$\mathbf{2}$ & 6,70 & 0,90 & 5,70 & 0,51 & 11,53 & 0,69 & 9,80 & 3,47 \\
$\mathbf{4}$ & 6,27 & 3,16 & 8,57 & 2,07 & 10,47 & 0,37 & 8,67 & 0,83 \\
$\mathbf{6}$ & 6,70 & 5,00 & 10,27 & 1,05 & 11,10 & 2,80 & 14,10 & 2,05 \\
$\mathbf{2 4}$ & 7,53 & 1,51 & 9,10 & 3,73 & 12,65 & 2,75 & 9,07 & 0,34 \\
\hline
\end{tabular}

Tabela A.2 - Valores referentes à influência do CEE isolado em células marcadas para rodamina 123, avaliando o percentual de mitocôndrias ativas. Os valores foram graficamente representados no gráfico 4.3, como B16F10 (A) e FN1 (B).

\begin{tabular}{|c|c|c|c|c|c|c|c|c|}
\hline \multirow{2}{*}{$\begin{array}{l}\text { Tempo } \\
\text { (horas) }\end{array}$} & \multicolumn{8}{|c|}{ B16F10 \% } \\
\hline & Controle & var & CEE & var & Etopo. & var & $\begin{array}{l}\text { CEE + } \\
\text { Etop. }\end{array}$ & var \\
\hline 2 & 86,60 & 1,18 & 88,87 & 1,86 & 89,53 & 2,82 & 87,83 & 3,23 \\
\hline 4 & 90,55 & 1,18 & 91,10 & 0,43 & 89,90 & 1,56 & 88,15 & 2,22 \\
\hline 6 & 91,23 & 1,44 & 91,83 & 1,06 & 91,75 & 1,58 & 86,17 & 0,54 \\
\hline 24 & 87,40 & 1,34 & 88,00 & 1,02 & 86,50 & 0,08 & 87,03 & 2,39 \\
\hline & \multicolumn{8}{|c|}{ FN1 \% } \\
\hline 2 & 85,97 & 0,96 & 89,70 & 2,00 & 80,67 & 1,72 & 78,03 & 2,04 \\
\hline 4 & 85,53 & 2,03 & 87,70 & 0,86 & 85,20 & 0,90 & 91,27 & 2,13 \\
\hline 6 & 88,37 & 2,75 & 88,30 & 1,63 & 89,87 & 1,39 & 90,08 & 4,56 \\
\hline 24 & 87,75 & 0,15 & 88,43 & 4,75 & 88,37 & 2,39 & 80,85 & 0,43 \\
\hline
\end{tabular}

Tabela A.3 - Valores referentes à influência do CEE isolado em células marcadas para rodamina 123, avaliando o percentual da atividade mitocondrial. Os valores foram graficamente representados no gráfico 4.4, como B16F10 (A) e FN1 (B).

\begin{tabular}{cccccccccc}
\hline \multirow{2}{*}{$\begin{array}{c}\text { Tempo } \\
\text { (horas) }\end{array}$} & \multicolumn{9}{c}{ B16F10 \% } \\
\cline { 2 - 10 } & Controle & var & CEE & var & Controle & var & CEE & var \\
$\mathbf{2}$ & 99,31 & 3,46 & 66,37 & 2,64 & 93,35 & 5,13 & 80,35 & 2,62 \\
$\mathbf{4}$ & 91,91 & 2,62 & 75,89 & 2,38 & 99,98 & 1,64 & 81,95 & 6,55 \\
$\mathbf{6}$ & 93,87 & 0,81 & 78,45 & 1,05 & 99,30 & 3,90 & 80,97 & 1,99 \\
$\mathbf{2 4}$ & 90,59 & 1,39 & 81,57 & 2,46 & 88,75 & 0,55 & 76,98 & 8,17 \\
\hline
\end{tabular}


Tabela A.4 - Valores referentes à influência do CEE isolado em células B16F10 marcadas com Anexina V/PI, graficamente representados no gráfico 4.5 .

\begin{tabular}{ccccccccc}
\hline $\begin{array}{c}\text { Tempo } \\
\text { (horas) }\end{array}$ & \multicolumn{8}{c}{ B16F10 - Controle \% } \\
& Vivas & var & Necrose & var & $\begin{array}{c}\text { Apopt. } \\
\text { Inicial }\end{array}$ & var & $\begin{array}{c}\text { Apopt. } \\
\text { Tardia }\end{array}$ & var \\
$\mathbf{2}$ & 96,37 & 1,54 & 0,50 & 0,29 & 4,95 & 2,32 & 1,07 & 96,37 \\
$\mathbf{4}$ & 96,70 & 3,54 & 1,48 & 0,93 & 0,90 & 1,92 & 0,53 & 96,70 \\
$\mathbf{6}$ & 95,00 & 2,08 & 0,48 & 0,13 & 1,15 & 0,46 & 0,13 & 95,00 \\
& & & & \multicolumn{1}{c}{ B16F10 - CEE \% } & & & \\
$\mathbf{2}$ & 94,40 & 2,59 & 1,77 & 0,69 & 1,68 & 1,29 & 0,53 & 0,40 \\
$\mathbf{4}$ & 95,90 & 2,03 & 0,437 & 0,69 & 1,43 & 0,45 & 0,53 & 0,37 \\
$\mathbf{6}$ & 96,80 & 0,77 & 1,037 & 0,23 & 5,75 & 0,86 & 0,23 & 0,19 \\
\hline
\end{tabular}

Tabela A.5 - Valores referentes à influência do CEE isolado em células FN1 marcadas com Anexina V/PI, graficamente representados no gráfico 4.6.

\begin{tabular}{|c|c|c|c|c|c|c|c|c|}
\hline \multirow{2}{*}{$\begin{array}{l}\text { Tempo } \\
\text { (horas) }\end{array}$} & \multicolumn{8}{|c|}{ FN1 - Controle \% } \\
\hline & Vivas & var & Necrose & var & $\begin{array}{l}\text { Apopt. } \\
\text { Inicial }\end{array}$ & var & $\begin{array}{l}\text { Apopt. } \\
\text { Tardia }\end{array}$ & var \\
\hline 2 & 93,55 & 0,75 & 3,45 & 0,55 & 0,47 & 0,59 & 1,30 & 0,57 \\
\hline 4 & 95,37 & 1,27 & 2,45 & 1,61 & 1,53 & 2,94 & 1,68 & 0,86 \\
\hline \multirow[t]{2}{*}{6} & 89,85 & 1,85 & 2,43 & 1,45 & 5,15 & 3,72 & 1,63 & 1,10 \\
\hline & \multicolumn{8}{|c|}{ FN1 - CEE \% } \\
\hline 2 & 92,40 & 5,50 & 6,20 & 0,58 & 0,45 & 0,57 & 0,07 & 0,05 \\
\hline 4 & 91,55 & 2,35 & 1,27 & 4,76 & 6,60 & 4,76 & 1,13 & 0,36 \\
\hline 6 & 85,05 & 9,10 & 2,20 & 0,53 & 4,95 & 0,53 & 2,10 & 0,85 \\
\hline
\end{tabular}

\section{A.4. Valores dos experimentos com o Campo Elétrico Estático Associado com Quimioterápico}

Tabela A.6 - Valores referentes à influência do CEE associado ao Etoposídeo na Viabilidade Celular, via MTT. Os valores foram graficamente representados no gráfico 4.7, como B16F10 (A) e FN1 (B).

\begin{tabular}{ccccccccc}
\hline Etop. & \multicolumn{4}{c}{ B16F10 \% } & \multicolumn{5}{c}{ FN1 \% } \\
\cline { 2 - 9 } & Controle & var & CEE & var & Controle & var & CEE & var \\
mmol & & & & & & & & \\
$\mathbf{0}$ & 100 & 10,30 & 77,75 & 5,43 & 100 & 11,8 & 76,35 & 5,55 \\
$\mathbf{0 , 1 0 2}$ & 81,54 & 2,37 & 54,99 & 0,35 & 77,92 & 1,09 & 51,77 & 1,39 \\
$\mathbf{0 , 2 1 2}$ & 71,12 & 0,07 & 34,67 & 6,34 & 71,16 & 2,99 & 38,00 & 1,53 \\
$\mathbf{0 , 4 2 5}$ & 44,92 & 5,82 & 21,70 & 1,63 & 43,37 & 10,30 & 2.00 & 5,82 \\
$\mathbf{0 , 8 5}$ & 24,16 & 6,13 & 13,68 & 0,50 & 20,04 & 10,30 & 19,87 & 3,15 \\
\hline
\end{tabular}


Tabela A.7 - Valores referentes à influência do CEE associado ao Paclitaxel na Viabilidade Celular, via MTT. Os valores foram graficamente representados no gráfico 4.10, como B16F10 (A) e FN1 (B).

\begin{tabular}{lcccccccc}
\hline Paclit. & \multicolumn{4}{c}{ B16F10 \% } & \multicolumn{5}{c}{ FN1 \% } \\
\cline { 2 - 9 } mmol & Controle & var & CEE & var & Controle & var & CEE & var \\
& 100,00 & 8,56 & 77,75 & 100,00 & 100,00 & 7,60 & 76,35 & 5,55 \\
$\mathbf{0 , 4 2}$ & 81,54 & 2,37 & 54,98 & 81,54 & 48,97 & 1,94 & 50,20 & 1,01 \\
$\mathbf{0 , 8 5}$ & 71,12 & 0,07 & 34,67 & 71,12 & 36,69 & 3,73 & 35,36 & 1,78 \\
$\mathbf{1 , 7 0}$ & 44,92 & 5,82 & 21,70 & 44,92 & 33,37 & 4,45 & 32,04 & 3,48 \\
$\mathbf{2 , 3 4}$ & 24,16 & 6,13 & 13,68 & 24,16 & 29,63 & 4,43 & 28,36 & 5,59 \\
\hline
\end{tabular}

A.4.1. Interpretação da Razão entre as Viabilidades

$\mathrm{F}_{(\mathrm{Q})}=$ Fator de redução da viabilidade decorrente da redução do quimioterápico.

$\mathrm{F}_{(\mathrm{Q}+\mathrm{C})}=$ Fator de redução da viabilidade decorrente da redução da aplicação combinada do quimioterápico com o Campo Elétrico (CE), em que

$$
\mathrm{F}_{(\mathrm{Q}+\mathrm{C})}=\mathrm{F}_{(\mathrm{Q})} \cdot \mathrm{F}_{(\mathrm{CE})},
$$

Sendo $\mathrm{F}(\mathrm{CE})$ = fator de redução devido à ação do $\mathrm{CE}$ (quando associado ao quimioterápico)

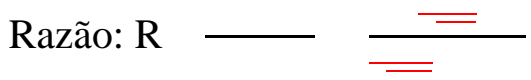

Portanto, R

Se nenhum efeito provocado pelo Campo Elétrico

Se ， há algum efeito devido ao Campo Elétrico

Uma vez que

$\mathrm{R}-$

Quanto maior

Exemplo: se

ou seja, o CE aumenta em 50\% o efeito isolado do Quimioterápico. 
Tabela A.8: Razão dos valores referentes à influência do CEE associado ao Etoposídeo na Viabilidade Celular, baseado na conversão dos valores da tabela A.6 e graficamente representados no gráfico 4.11, como B16F10 (A) e FN1 (B). Os valores da variância não foram representados por serem os mesmos da tabela A.6.

\begin{tabular}{ccc}
\hline Etop. & B16F10 & FN1 \\
\cline { 2 - 3 } mmol & Razão do & Controle \\
$\mathbf{0}$ & CEE & CEE \\
$\mathbf{0 , 1 0 2}$ & 0,78 & 0,76 \\
$\mathbf{0 , 2 1 2}$ & 0,67 & 0,66 \\
$\mathbf{0 , 4 2 5}$ & 0,49 & 0,53 \\
$\mathbf{0 , 8 5}$ & 0,45 & 0,40 \\
\hline
\end{tabular}

Gráfico 4.12: Valores referentes à influência do tempo entre a aplicação do Etoposídeo e posterior associação com o CEE, determinada pela Viabilidade Celular via MTT das células FN1. Os valores foram graficamente representados no gráfico 4.12.

\begin{tabular}{ccc} 
Intervalo de Tempo (horas) & CEE \% & Variância \% \\
\hline $\mathbf{0}$ & 53,57 & 5,81 \\
$\mathbf{1}$ & 19,88 & 7,70 \\
$\mathbf{2}$ & 7,51 & 3,37 \\
\hline
\end{tabular}

\section{A.4.2. Valores dos experimentos para Marcadores Celulares dos efeitos do Campo Elétrico Estático Associado com o Etoposídeo}

Tabela A.9 - Valores referentes à influência do CEE associado ao Etoposídeo em células marcadas com caspase 3. Os valores foram graficamente representados no gráfico 4.13, como B16F10 (A) e FN1 (B).

\begin{tabular}{|c|c|c|c|c|c|c|c|c|}
\hline \multirow{2}{*}{$\begin{array}{l}\text { Tempo } \\
\text { (horas) }\end{array}$} & \multicolumn{4}{|c|}{ B16F10 \% } & \multicolumn{4}{|c|}{ FN1 \% } \\
\hline & Etoposídeo & var & $\begin{array}{l}\text { CEE + } \\
\text { Etop. }\end{array}$ & var & $\begin{array}{c}\text { Etoposíd } \\
\text { eo }\end{array}$ & var & $\begin{array}{c}\text { CEE + } \\
\text { Etop. }\end{array}$ & var \\
\hline 2 & 26,40 & 3,54 & 23,20 & 4,70 & 26,40 & 3,54 & 23,20 & 4,70 \\
\hline 4 & 19,57 & 0,87 & 24,37 & 2,51 & 19,57 & 0,87 & 24,37 & 2,51 \\
\hline 6 & 15,30 & 1,41 & 29,55 & 4,95 & 15,30 & 1,41 & 29,55 & 4,95 \\
\hline 24 & 16,25 & 2,05 & 34,25 & 2,65 & 16,25 & 2,05 & 34,25 & 2,65 \\
\hline
\end{tabular}

Tabela A.9 - Valores referentes à influência do CEE associado ao Etoposídeo em células B16F10 marcadas com anexina V/PI. Os valores foram graficamente representados no gráfico 4.14 .

\begin{tabular}{|c|c|c|c|c|c|c|c|c|}
\hline \multirow{2}{*}{$\begin{array}{l}\text { Tempo } \\
\text { (horas) }\end{array}$} & \multicolumn{8}{|c|}{ B16F10 - Etoposídeo \% } \\
\hline & Vivas & var & Necrose & var & $\begin{array}{l}\text { Apopt. } \\
\text { Inicial }\end{array}$ & var & $\begin{array}{l}\text { Apopt. } \\
\text { Tardia }\end{array}$ & var \\
\hline 2 & 71,87 & 7,52 & 15,35 & 2,15 & 6,10 & 1,97 & 5,85 & 1,95 \\
\hline 4 & 73,25 & 6,39 & 9,53 & 4,11 & 7,95 & 2,05 & 9,40 & 0,60 \\
\hline \multirow[t]{2}{*}{6} & 84,17 & 7,58 & 5,48 & 2,20 & 6,70 & 1,40 & 7,10 & 1,75 \\
\hline & \multicolumn{8}{|c|}{ B16F10 - CEE + Etoposídeo \% } \\
\hline 2 & 80,05 & 6,63 & 6,08 & 1,58 & 11,37 & 2,02 & 2,25 & 1,09 \\
\hline 4 & 65,50 & 6,30 & 7,03 & 5,40 & 15,37 & 0,62 & 12,65 & 2,49 \\
\hline 6 & 60,10 & 1,03 & 4,95 & 0,85 & 32,95 & 1,85 & 2,40 & 0,70 \\
\hline
\end{tabular}


Tabela A.10 - Valores referentes à influência do CEE associado ao Etoposídeo em células FN1 marcadas com anexina V/PI. Os valores foram graficamente representados no gráfico 4.15 .

\begin{tabular}{|c|c|c|c|c|c|c|c|c|}
\hline \multirow{2}{*}{$\begin{array}{l}\text { Tempo } \\
\text { (horas) }\end{array}$} & \multicolumn{8}{|c|}{ FN1 - Etoposídeo \% } \\
\hline & Vivas & var & Necrose & var & $\begin{array}{l}\text { Apopt. } \\
\text { Inicial }\end{array}$ & var & $\begin{array}{l}\text { Apopt. } \\
\text { Tardia }\end{array}$ & var \\
\hline 2 & 74,45 & 8,65 & 23,50 & 7,67 & 0,47 & 0,66 & 0,58 & 0,47 \\
\hline 4 & 77,70 & 8,70 & 6,60 & 1,28 & 7,67 & 4,41 & 2,13 & 0,78 \\
\hline \multirow[t]{2}{*}{6} & 77,40 & 7,90 & 9,53 & 4,37 & 9,10 & 4,80 & 0,50 & 0,75 \\
\hline & \multicolumn{8}{|c|}{ FN1 - CEE + Etoposídeo \% } \\
\hline 2 & 77,00 & 7,30 & 19,97 & 5,58 & 2,35 & 1,70 & 1,30 & 0,49 \\
\hline 4 & 56,67 & 4,82 & 10,83 & 3,92 & 17,35 & 1,01 & 11,40 & 5,20 \\
\hline 6 & 55,68 & 5,67 & 18,17 & 5,25 & 12,85 & 2,55 & 8,20 & 2,00 \\
\hline
\end{tabular}

Tabela A.11 - Valores referentes à influência do CEE associado ao Etoposídeo em células marcadas com rodamina 123, avaliando a atividade mitocondrial. Os valores foram graficamente representados no gráfico 4.13, como B16F10 (A); FN1 (B) e para todos os grupos experimentais com B16F10 (C) e FN1 (D). Os valores de Controle e CEE isolados são os mesmos da Tabela A.3.

\begin{tabular}{|c|c|c|c|c|c|c|c|c|}
\hline \multirow{2}{*}{$\begin{array}{r}\text { Tempo } \\
\text { (horas) }\end{array}$} & \multicolumn{8}{|c|}{ B16F10 \% } \\
\hline & Controle & var & CEE & var & Etopo. & var & $\begin{array}{c}\text { CEE + } \\
\text { Etop. }\end{array}$ & var \\
\hline 2 & 99,31 & 3,46 & 66,37 & 2,64 & 82,27 & 2,50 & 77,25 & 2,24 \\
\hline 4 & 91,91 & 2,62 & 75,89 & 2,38 & 84,50 & 1,35 & 74,10 & 2,86 \\
\hline 6 & 93,87 & 0,81 & 78,45 & 1,05 & 86,17 & 0,54 & 74,40 & 3,70 \\
\hline \multirow[t]{2}{*}{24} & 90,59 & 1,39 & 81,57 & 2,46 & 90,15 & 0,18 & 82,90 & 1,60 \\
\hline & \multicolumn{8}{|c|}{ FN1 \% } \\
\hline 2 & 93,35 & 5,13 & 80,35 & 2,62 & 75,70 & 0,60 & 78,37 & 1,93 \\
\hline 4 & 99,98 & 1,64 & 81,95 & 6,55 & 85,33 & 2,85 & 81,28 & 1,64 \\
\hline 6 & 99,30 & 3,90 & 80,97 & 1,99 & 96,35 & 4,54 & 81,05 & 5,65 \\
\hline 24 & 88,75 & 0,55 & 76,98 & 8,17 & 95,53 & 2,70 & 86,97 & 0,55 \\
\hline
\end{tabular}

